\title{
Coastal Ocean Variability off the Coast of Taiwan in Response to Typhoon Morakot: River Forcing, Atmospheric Forcing, and Cold Dome Dynamics
}

\author{
by \\ Jennifer Jacobs Landry \\ B.S., Denison University (2003) \\ Submitted in partial fulfillment of the requirements for the degree of \\ Master of Science \\ at the \\ MASSACHUSETTS INSTITUTE OF TECHNOLOGY \\ and the \\ WOODS HOLE OCEANOGRAPHIC INSTITUTION \\ September 2014 \\ (C) Jennifer Jacobs Landry, MMXIV. All rights reserved. \\ The author hereby grants to MIT and WHOI permission to reproduce and to distribute \\ publicly paper and electronic copies of this thesis document in whole or in part in any \\ medium now known or hereafter created.
}

Author

Department of Mechanical Engineering and Department of Applied Ocean Science and Engineering August 8, 2014

Certified by

Dr. Pierre F. J. Lermusiaux

Associate Professor of Mechanical Engineering

Thesis Supervisor Massachusetts Institute of Technology

Accepted by

Dr. Henrik Schmidt

Professor of Mechanical and Ocean Engineering Chair, Joint Committee for Applied Ocean Science and Engineering Massachusetts Institute of Technology

Accepted by

Dr. David E. Hardt

Professor of Mechanical Engineering

Chair, Mechanical Engineering Committee on Graduate Students

Massachusetts Institute of Technology 
Coastal Ocean Variability off the Coast of Taiwan

\author{
in Response to Typhoon Morakot: \\ River Forcing, Atmospheric Forcing, and \\ Cold Dome Dynamics
}

\author{
by \\ Jennifer Jacobs Landry \\ Submitted to the Department of Mechanical Engineering and \\ Department of Applied Ocean Science and Engineering \\ on August 8, 2014, in partial fulfillment of the \\ requirements for the degree of \\ Master of Science
}

\begin{abstract}
The ocean is a complex, constantly changing, highly dynamical system. Prediction capabilities are constantly being improved in order to better understand and forecast ocean properties for applications in science, industry, and maritime interests. Our overarching goal is to better predict the ocean environment in regions of complex topography with a continental shelf, shelfbreak, canyons and steep slopes using the MIT Multidisciplinary Simulation, Estimation and Assimilation Systems (MSEAS) primitive-equation ocean model. We did this by focusing on the complex region surrounding Taiwan, and the period of time immediately following the passage of Typhoon Morakot. This area and period were studied extensively as part of the intense observation period during August - September 2009 of the joint U.S. - Taiwan program Quantifying, Predicting, and Exploiting Uncertainty Department Research Initiative (QPE DRI). Typhoon Morakot brought an unprecedented amount of rainfall within a very short time period and in this research, we model and study the effects of this rainfall on Taiwan's coastal oceans as a result of river discharge. We do this through the use of a river discharge model and a bulk river-ocean mixing model. We complete a sensitivity study of the primitive-equation ocean model simulations to the different parameters of these models. By varying the shape, size, and depth of the bulk mixing model footprint, and examining the resulting impacts on ocean salinity forecasts, we are able to determine an optimal combination of salinity relaxation factors for highest accuracy.
\end{abstract}

Thesis Supervisor: Dr. Pierre F. J. Lermusiaux Title: Associate Professor of Mechanical Engineering Massachusetts Institute of Technology 



\section{Acknowledgments}

I would like to thank to my advisor, Prof. Pierre Lermusiaux, for his knowledge, friendship, encouragement, advice, and endless positivity as he guided me through this experience. I truly appreciate his flexibility and support in helping me to develop a project that combined my personal and professional interests. It was only with the help of many others that this project was completed. Pat: thank you for sharing your seemingly limitless expertise and patience. Chris and Jordan: thank you for your instrumental help and support in completing this thesis. Matt: thank you for being the other half of an excellent, if small, wardroom. Tapovan, Deepak and Sydney: thank you for your assistance and friendship. I would also like to thank the current and alumni MSEAS team for their contributions: Jing, Wayne, Marcia, Sam, Matt, Akash, and John.

My education in the MIT-WHOI Joint Program in Oceanography was fully funded by the United States Navy. I will always be grateful for this opportunity.

With the MSEAS group, we are grateful to the Office of Naval Research for research support under grants N00014-08-1-0586 (QPE) to the Massachusetts Institute of Technology, and to the QPE team of Taiwanese and US researchers for their fruitful collaborations. We especially thank Dr. Glen Gawarkiewicz and Dr. Sen Jan, as well as all of the colleagues involved in collecting observations that allowed the present study.

This work is dedicated to my parents who have always supported me and overestimated my abilities so that I could achieve more than I believed to be possible. This life is dedicated to Norm Landry, my favorite person in the world; I thank you more than words can ever say for everything you are. 
THIS PAGE INTENTIONALLY LEFT BLANK 


\section{Contents}

1 Introduction $\quad 17$

2 Background and Literature Review $\quad 19$

2.1 Taiwan . . . . . . . . . . . . . . . . . . . 19

2.1.1 Taiwan Oceans and Topography . . . . . . . . . . . 20

2.1.2 Taiwan Ocean Features . . . . . . . . . . . . . . . . 21

2.2 Quantifying, Predicting, and Exploiting Uncertainty Department Research Initiative . . . . . . . . . . . . . . . . . . . . . . . 24

2.2.1 Motivation for and Goals of the QPE DRI . . . . . . . . . 24

2.2.2 IOP Observation Plan ................ 25

2.3 MSEAS Primitive-Equation Ocean Model . . . . . . . . . . . . 27

2.4 Typhoon Morakot . . . . . . . . . . . . . . . 28

2.4 .1 Typhoon Morakot Overview . . . . . . . . . . . . . 28

2.4.2 Precipitation from Typhoon Morakot . . . . . . . . . . 29

2.5 River Discharge Model . . . . . . . . . . . . . . . . . . . . 31

2.5.1 River Discharge Model Concept . . . . . . . . . . . . . 31

2.5.2 Precipitation Estimation and Drainage Basins . . . . . . . . 33

2.5.3 Time Dependency of River Discharge . . . . . . . . . . . 34

2.5.4 Forcing the MSEAS Ocean Model with the River Discharge Model 37

2.6 Preliminary Results of the Original River Discharge Model . . . . . . 38

3 Methods $\quad 41$

3.1 Bulk Mixing Model of River and Ocean Waters . . . . . . . . . . 41 
3.1.1 Derivation of Salinity Forcing Function . . . . . . . . . . . . . 42

3.1 .2 A Note on Indexing . . . . . . . . . . . . . . 46

3.2 Potential Improvements to the River Discharge Model and Bulk Mixing Model ......................... 46

3.2.1 Time Series Estimation for River Discharge . . . . . . . . . 47

3.2.2 Depth of Selected Finite-Volume Grid Cells in the Bulk Mixing Model ........................ . . 49

3.2.3 Salinity Relaxation Values . . . . . . . . . . . . . . 53

3.2.4 Number and Shape of Selected Grid Cells . . . . . . . . . . 53

3.3 Sensitivity Studies of the MSEAS Ocean Model . . . . . . . . . . 54

4 Results $\quad 57$

4.1 Effects of Footprint Shape on the Bulk Mixing Model . . . . . . . . . 57

4.2 Effects of the Horizontal Extent of the Bulk Mixing Model . . . . . . 59

4.3 Effects of the Depth of the Bulk Mixing Model . . . . . . . . . . . . . 60

4.4 Final Results . . . . . . . . . . . . . . . . . . . . . 61

$\begin{array}{lll}5 & \text { Conclusion } & 75\end{array}$

5.1 Future Work . . . . . . . . . . . . . . . . 76

5.1.1 Variation of Salinity Relaxation Factors . . . . . . . . . . . 76

5.1.2 MSEAS Primitive-Equation Model . . . . . . . . . . 76

5.1 .3 New Discharge Data . . . . . . . . . . . . . 77 


\section{List of Figures}

2-1 Bathymetric chart and topography in the seas surrounding Taiwan. (Rudnick et al., 2011) . . . . . . . . . . . . . 20

2-2 Surface currents of the Pacific Ocean, shown during winter monsoon season. (Talley et al., 2011) . . . . . . . . . . . . . . . 22

2-3 Origins of the Kuroshio current. (Rudnick et al., 2011) . . . . . . . . 22

2-4 Seasonal variations in the Kuroshio near Taiwan. (Rudnick et al., 2011) 23

2-5 Three-dimensional rendering of cold dome formation. (Jan et al., 2011) 24

2-6 Map of observing plan for QPE IOP. Triangles indicate CTD drops of $R / V$ Ocean Researcher 2 (OR2) and squares indicate CTD drops of $R / V$ Ocean Researcher 3 (OR3). Yellow star is a biogeochemcial sampling station, and gray arrows show mean current velocity, taken from historical ADCP data. Red dashed line shows the track of Typhoon Morakot. (Jan et al., 2013) . . . . . . . . . . . 26

2-7 Satellite image of Typhoon Morakot on 06 August 2009 at 0525Z, taken by Moderate Resolution Imaging Spectroradiometer (MODIS) aboard the NASA Aqua satellite. (NASA/MODIS Rapid Response, 2009) . .

2-8 Precipitation estimates for rainfall associated with Typhoon Morakot obtained from (a) NASA's Tropical Rainfall Measuring Mission satellites (SSAI/NASA, Hal Pierce, 2009), (b) nowcast from the NRL's Coupled Ocean/Atmosphere Mesoscale Prediction System (COAMPS) (Naval Research Laboratory, 2012), and (c) the Taiwan Central Geologial Survey in-situ measurements (Liu, 2010). . . . . . . . . . . . . . 30

2-9 Schematic of river discharge model control volume. . . . . . . . . . . 32 
2-10 Figures used in estimation of individual river discharge. (a) Map of major rivers of Taiwan. (b) Watersheds in Taiwan and model discharge basin boundaries. Numbers indicate mouths of major rivers, while shading indicates River Discharge Model drainage basins. (Mirabito et al., 2012) . . . . . . . . . . . . . . . . . . .

2-11 Discharge rates for each river as computed by this method, with the actual data replacing the time series for the Zhuóshuǐ and Gāopíng Rivers. (Mirabito et al., 2012) . . . . . . . . . . . . . 37

2-12 Surface salinities forecast by the MSEAS ocean model with no river forcing (left column) and with river discharge model (right column). (Mirabito et al., 2012) . . . . . . . . . . . . . .

3-1 Diagram of salinity fluxes into and out of the control volume for (a) a model without freshwater discharge and (b) a model with freshwater discharge added. . . . . . . . . . . . . . .

3-2 Historical Best Track for Typhoon Morakot. (Cooper and Falvey, 2009,

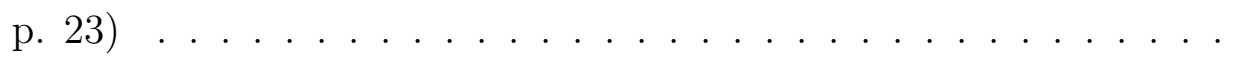

3-3 Discharge Data for the Zhuóshuǐi and Gāopíng Rivers from 5 - 14 August. (Mirabito et al., 2012) . . . . . . . . . . .

3-4 (a) Map of CTD drop locations northeast of Taiwan, taken by the $R / V$ Ocean Researcher 2 (OR2) during the period 13 - 17 August, 2009. (b) Salinity profiles from these CTD casts. (Leslie, 2012) . . . . . . . . 50

3-5 (a) Map of CTD drop locations northeast of Taiwan, taken by the $R / V$ Ocean Researcher 3 (OR3) during the period 13 - 17 August, 2009. (b) Salinity profiles from these CTD casts. (Leslie, 2012) . . . . . . . 51

3-6 Salinity profiles and locations of low salinity observations in the wake of Typhoon Morakot. (Leslie, 2012) . . . . . . . . . . . 
3-7 Comparison of grid cell configurations. Salinity relaxation grid cells are marked with red boxes.(a) Original configuration. (b) A new configuration, called Test 5, maintaining original $n=7$ grid cells per river. (c) Another new configuration, called Test 6 , with $n=7$ grid cells per river. (d) A configuration, called Test 7 , increasing to $n=10$ grid cells per river. (e) A configuration, called Test 8, increasing to $\mathrm{n}=14$ grid cells per river. (f) A configuration, called Test 9, increasing to $n=25$ grid cells per river. . . . . . . . . . . . . . . . . 55

4-1 Map of CTD drop locations taken by the $R / V$ Ocean Researcher 2 (OR2) during the period 13 - 17 August, 2009. This is a combination of the data profiles shown in Figures 3-5(a) and 3-4(a). (Leslie, 2012)

4-2 Salinity profiles taken 13 - 17 August 2009 for the six locations that have been identified as being impacted by freshwater river discharge by Newhall et al. (2010). (a) shows salinity variations with depth in these six profiles, while (b) shows the locations of these profiles. . . . 59

4-3 Surface salinities forecast by the MSEAS ocean model with no river forcing. This run was completed for comparison purposes. . . . . . .

4-4 Surface salinities forecast by the MSEAS ocean model with the original river forcing, using $n=7$ finite-volume cells, with salinity relaxation applied to a depth of $10 \mathrm{~m}$. The configuration is shown in Figure 3-7(a). This run was completed for comparison purposes. . . . . . . .

4-5 Surface salinities forecast by the MSEAS ocean model with configuration Test 5 , using $\mathrm{n}=7$ finite-volume cells, with salinity relaxation applied to a depth of $10 \mathrm{~m}$. The configuration is shown in Figure

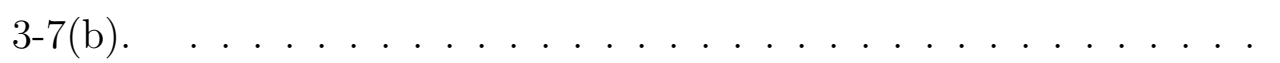

4-6 Surface salinities forecast by the MSEAS ocean model with configuration Test 6 , using $\mathrm{n}=7$ finite-volume cells, with salinity relaxation applied to a depth of $10 \mathrm{~m}$. The configuration is shown in Figure 3-7(c). 65 
4-7 Comparisons of salinity data with MSEAS salinity forecasts using different configurations of the bulk mixing model, with salinity relaxation to a depth of $10 \mathrm{~m}$. Plots show the data subtracted from the specified model output. The profile locations are shown in Figure 4-1. . . . . . 66

4-8 Comparisons of salinity data (in profiles with known river discharge influence (Newhall et al., 2010)) with MSEAS salinity forecasts using different configurations of the bulk mixing model, with salinity relaxation to a depth of $10 \mathrm{~m}$. Plots show the data subtracted from the specified model output. The profile locations and data are shown in Figure 4-2. . . . . . . . . . . . . . . . . . . . . .

4-9 Comparisons of salinity data (in profiles with known river discharge influence (Newhall et al., 2010)) with MSEAS salinity forecasts using different configurations of the bulk mixing model, with salinity relaxation to a depth of $10 \mathrm{~m}$. Plots show the data subtracted from the specified model output. The profile locations and data are shown in Figure 4-2. . . . . . . . . . . . . . . . . .

4-10 Comparisons of salinity data with MSEAS salinity forecasts using different configurations of the bulk mixing model, with salinity relaxation to a depth of $20 \mathrm{~m}$. Plots show the data subtracted from the specified model output. The profile locations are shown in Figure 4-1. . . . . .

4-11 Comparisons of salinity data (in profiles with known river discharge influence (Newhall et al., 2010)) with MSEAS salinity forecasts using different configurations of the bulk mixing model, with salinity relaxation to a depth of $20 \mathrm{~m}$. Plots show the data subtracted from the specified model output. The profile locations and data are shown in Figure $4-2 \ldots \ldots \ldots \ldots \ldots \ldots \ldots$ 
4-12 Comparisons of salinity data (in profiles with known river discharge influence (Newhall et al., 2010)) with MSEAS salinity forecasts using different configurations of the bulk mixing model, with salinity relaxation to a depth of $20 \mathrm{~m}$. Plots show the data subtracted from the specified model output. The profile locations and data are shown in Figure $4-2 \ldots \ldots \ldots \ldots \ldots \ldots$

4-13 Comparisons of salinity data (in profiles with known river discharge influence (Newhall et al., 2010)) with MSEAS salinity forecasts using the same 25 cell configuration of the bulk mixing model, with salinity relaxation to a depth of 10,15 , and $20 \mathrm{~m}$. Plots show the data subtracted from the specified model output. The profile locations and data are shown in Figure 4-2. . . . . . . . . . . . . . . . . . 72

4-14 Surface salinities forecast by the MSEAS ocean model with configuration Test 9 , using $\mathrm{n}=25$ finite-volume cells, with salinity relaxation applied to a depth of $10 \mathrm{~m}$. The configuration is shown in Figure 3-7(f).

4-15 Surface salinities forecast by the MSEAS ocean model with configuration Test 9 , using $\mathrm{n}=25$ finite-volume cells, with salinity relaxation applied to a depth of $10 \mathrm{~m}$. These results include data assimilation.

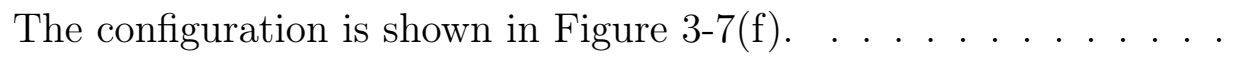

5-1 Discharge Data for the Gāopíng $(i=1)$, Zēngwén $(i=2)$, Zhuóshuǔi $(i=3)$, and $\mathrm{W} \overline{\mathrm{u}}(i=4)$ Rivers from August 2009. (Jan et al., 2013) . 
THIS PAGE INTENTIONALLY LEFT BLANK 


\section{List of Tables}

2.1 The eleven rivers of Taiwan used in the river discharge model and their assigned drainage basin. The relative strength of the annual mean discharge of each river within its basin determines the discharge

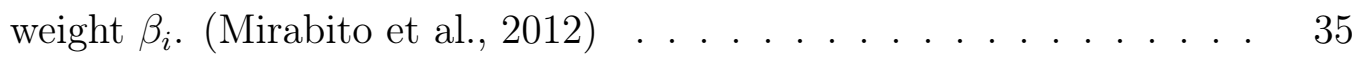

2.2 Average Discharge Rate by Basin. (Mirabito et al., 2012) . . . . . . . 35 
THIS PAGE INTENTIONALLY LEFT BLANK 


\section{Chapter 1}

\section{Introduction}

"The seas unite the world, no matter if individual nations are landlocked or not. Our individual sovereignties, our freedoms, and our prosperity are linked by the common medium of the oceans."

-Admiral Mike Mullen

The ocean has an enormous impact on our lives, and yet relatively little is known about it. The ocean is a complex, constantly changing, highly dynamical system. Harnessing the knowledge of the depths gives the advantage to the owner of that knowledge, whether his purpose is scientific research, navigation, fishing, acoustic communications, shipping, climate change, or naval warfighting.

In this work, our goal is to better predict the ocean environment in a region of region of complex topography with a continental shelf, shelfbreak, canyons and steep slopes. We add to the challenge the ocean's response to an extreme weather event. Today's ocean models resolve complex physical processes taking place on a wide range of spatial and temporal scales. Understanding the coupled ocean-atmosphere system and enhacing the performace of our models allows a reduction in uncertainty- an important factor in making the right decisions at the right time. The ability to 
reduce uncertainty in our knowledge of the surrounding environment, in both present and future situations, is the ability to gain the advantage.

Specifically, we study the region around Taiwan, in the aftermath of Typhoon Morakot in August 2009. The Quantifying, Predicting, and Exploiting Uncertainty Department Research Initiative (QPE DRI) seeks to answer these questions and more with a targeted observation period and modeling studies. Part of this DRI involved the coupling of observations with modeling studies, using the sophisticated ocean models from the Multidisciplinary Simulation, Estimation and Assimilation Systems (MSEAS) group at MIT. In the present research, we study the effects of the unprecedented rainfall on Taiwan's coastal oceans as a result of river discharge. We do this through the use of a river discharge model and a bulk river-ocean mixing model, and we refine that model to find the combination of input parameters that most closely represent observed ocean properties. Specifically, we complete a sensitivity study of the primitive-equation ocean model simulations to variations of the bulk mixing model parameters in the coastal regions directly adjacent to the river mouths.

Chapter two discusses the background information used for this research, a summary of the research initiative utilized in the project, and a description of the river discharge and river-ocean mixing models that we seek to improve upon. This chapter also includes a review of some of the literature that is applicable to this research. Chapter three describes the methods used and further developed in this research, outlining some of the steps taken and the reasoning for them. Chapter four describes the results obtained in the course of this research. Chapter five concludes the work and details possible future work. 


\section{Chapter 2}

\section{Background and Literature Review}

This chapter discusses the Taiwan region and complex oceanography, then provides an explanation of past projects used to study the region. The current state of the river discharge and bulk mixing model is examined.

\subsection{Taiwan}

Taiwan is an island in the northern west Pacific Ocean, about $180 \mathrm{~km}$ (100 miles) from the southeast coast of China. It is bordered by the Philippine Sea to the east, the Luzon Strait and South China Sea to the south, the Taiwan Strait to the west and the East China Sea to the north. The total landmass is $35,980 \mathrm{sq} \mathrm{km}$. The eastern part of the island is dominated by mountains, while the western part is flatter, and home to the majority of the island's 23 million people (U. S. Central Intelligence Agency, 2014). The climate is tropical, dominated by the winter northeasterly monsoons and

the weaker summer southwesterly monsoons (Rudnick et al., 2011). On average, 3 - 4 typhoons make landfall each season. The island lies along an active fault, and experiences frequent earthquakes (Taiwan Central Weather Bureau, 2014). 


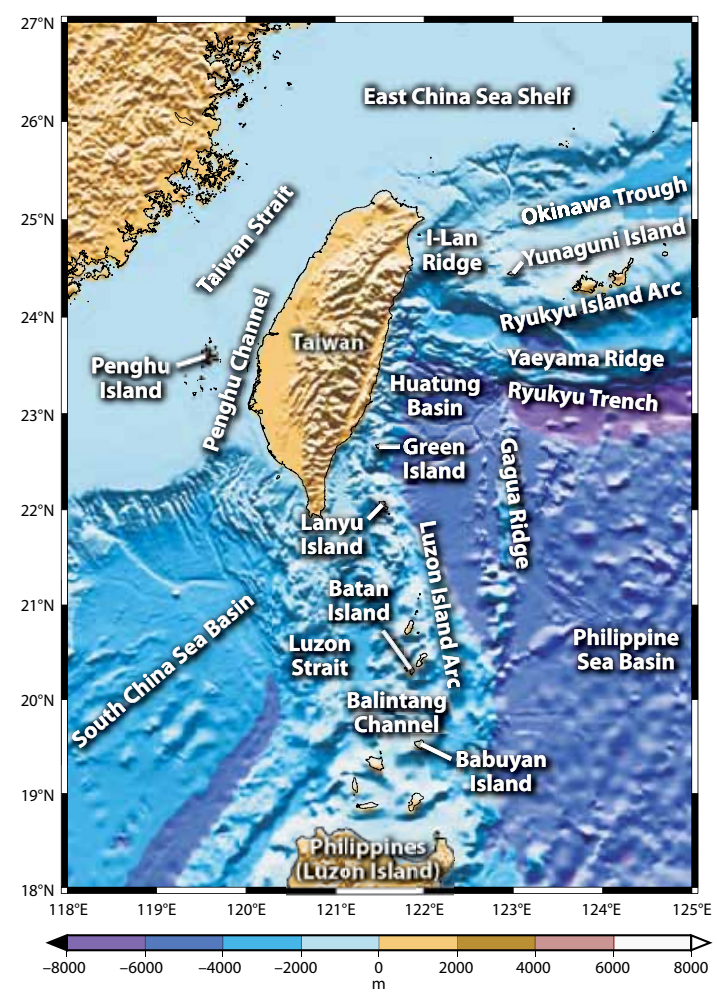

Figure 2-1: Bathymetric chart and topography in the seas surrounding Taiwan. (Rudnick et al., 2011)

\subsubsection{Taiwan Oceans and Topography}

The oceans surrounding Taiwan have a highly complex underwater topography. The island was formed when the Philippine Sea Plate subducted under the Eurasia Plate, (Jan et al., 2011) along the Ryukyu Trench (Rudnick et al., 2011). To the west of Taiwan is the continental shelf, and to the east is a steep continental slope, ending in the Huatung Basin, 6,200 $\mathrm{m}$ deep at its lowest point (Rudnick et al., 2011). A series of canyons (the Keelung Valley, the Mien-Hua Canyon, and the North MienHua Canyon) lie to the north of this basin, cutting across the shelf (Jan et al., 2011). To the east is a series of trenches and ridges, including the I-Lon Ridge (Jan et al., 2011). South of the Huatung, the Luzon Island Arc is the top of a series of underwater mountains, extending south to the larger Philippine Islands (Rudnick et al., 2011). See Figure 2-1. 


\subsubsection{Taiwan Ocean Features}

The region's oceanographic features are dominated by the Kuroshio current offshore to the east; an area of intermittent upwelling over the continental slope commonly referred to as the "cold dome" forms off the northeastern tip of the island (Tang et al., 1999).

As presented by Rudnick et al. (2011), the Kuroshio current is a western boundary current of the north Pacific subtropical gyre (see Figure 2-2). The Kuroshio, along with the westerly North Equatorial Current (NEC) and the southerly Mindanao current, forms the major circulation pattern in the northwest Pacific. The Kuroshio and the Mindanao split from the western edge of the NEC at the Philippine Islands as shown in Figure 2-3. The water masses making up the NEC are the North Pacific Tropical Water (NPTW), located by a salinity maximum at $200 \mathrm{~m}$, and the North Pacific Intermediate Water (NPIW), with a salinity minimum at $500 \mathrm{~m}$. Strong eddies form off the western boundary, near the coast of Taiwan.

The Kuroshio, like other north-south currents, is relatively narrow and swift, ranging between $80-100 \mathrm{~km}$, and having maximum speeds between 1.5-5 knots (Talley et al., 2011). The current, measured just northeast of Taiwan, has a mean transport of $21 \mathrm{~Sv}$ (Rudnick et al., 2011).

In the region surrounding Taiwan, specific seasonal changes in the current's path occur, shown in Figure 2-4. During winter, the Kuroshio is affected by the seasonal northeasterly monsoon and some Kuroshio water flows over the continental shelf. In summer, the monsoon shifts and the Kuroshio moves northeastward off the continental shelf. Local oceanographic properties are substantially impacted by this seasonal shift (Jan et al., 2011).

During the summer months, the Kuroshio is no longer opposed by the winter monsoon and turns away from the northeast corner of Taiwan. This allows the ocean north of Taiwan to be dominated by Taiwan Strait waters, which are fresher and

warmer than the surrounding waters. The passage of typhoons can disrupt this pattern, allowing cold, salty Kuroshio water to be brought to the surface via upwelling 


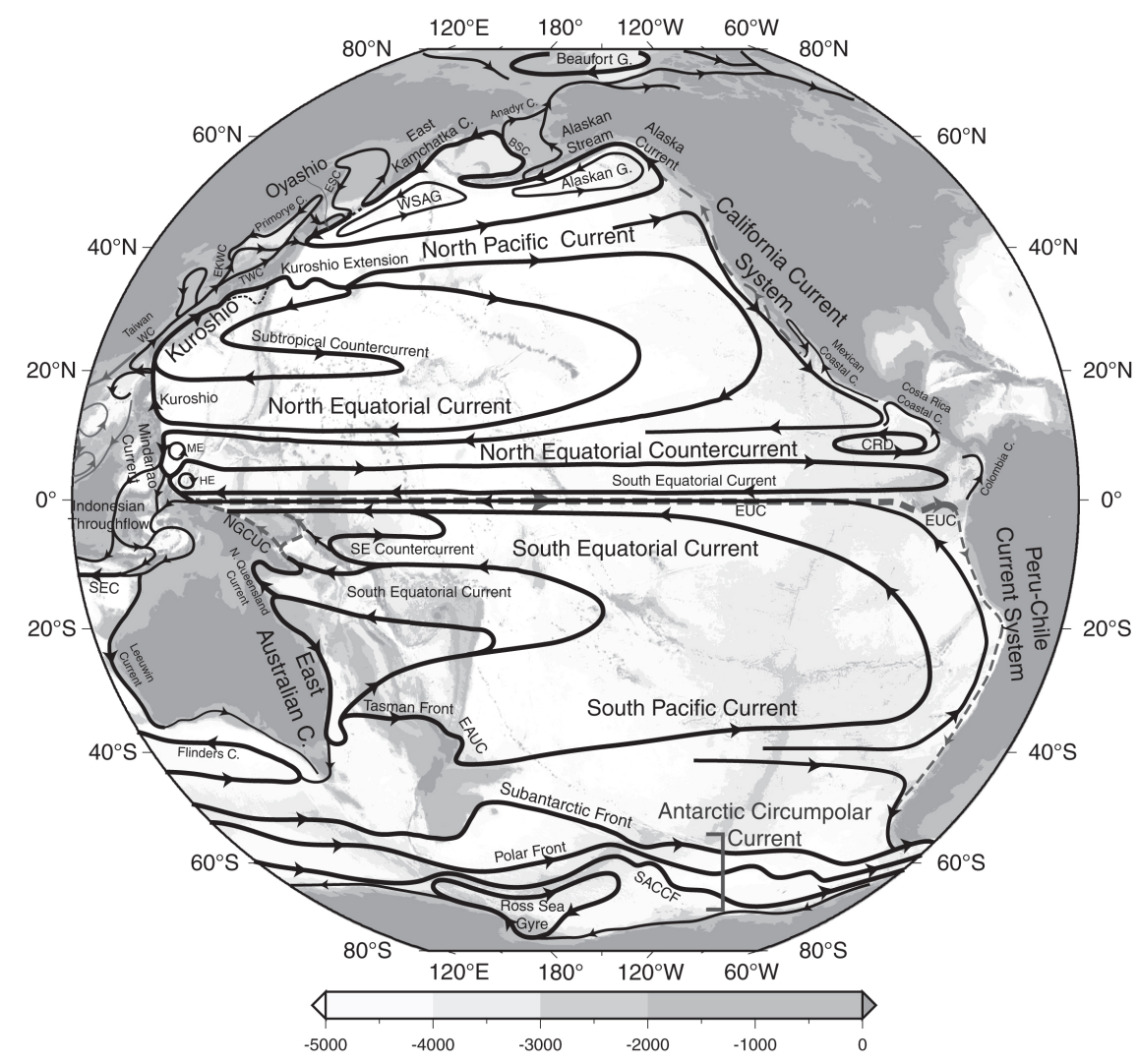

Figure 2-2: Surface currents of the Pacific Ocean, shown during winter monsoon season. (Talley et al., 2011)

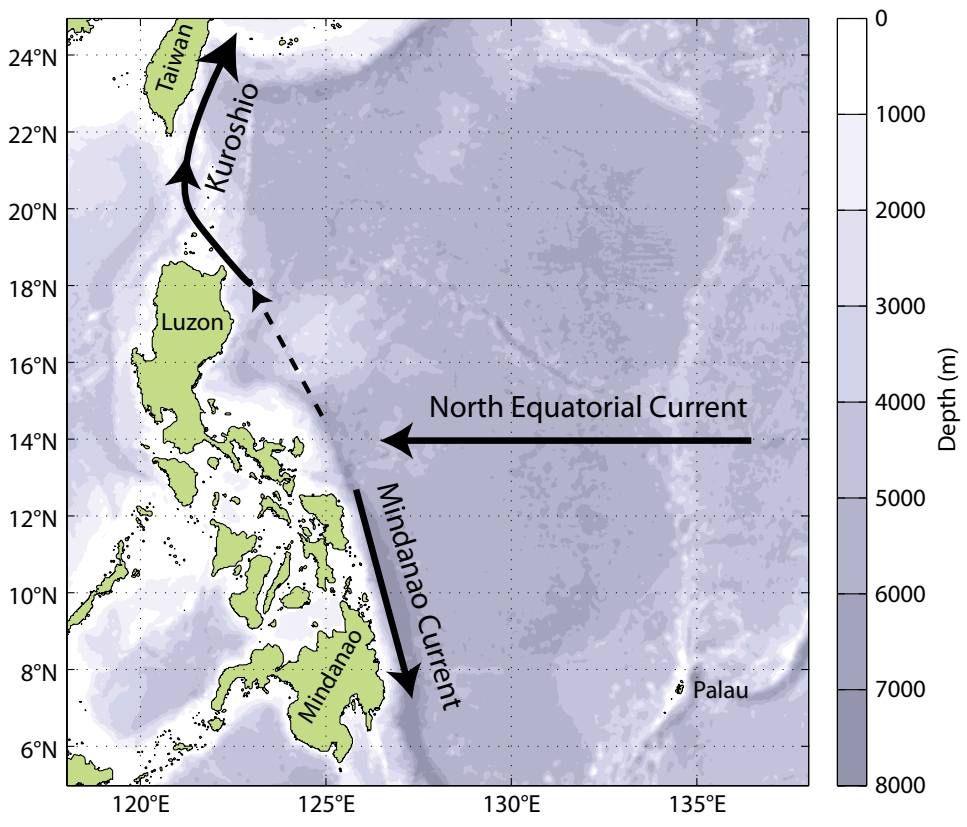

Figure 2-3: Origins of the Kuroshio current. (Rudnick et al., 2011) 
(a) Summer

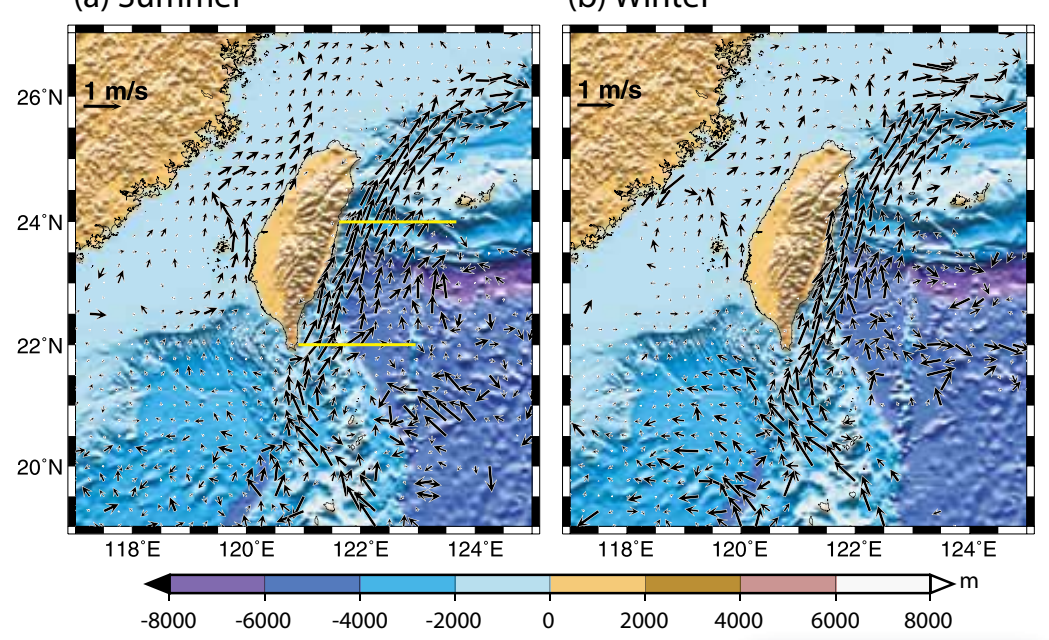

Figure 2-4: Seasonal variations in the Kuroshio near Taiwan. (Rudnick et al., 2011)

over the shelf. This water mixes with the shelf water, creating a relatively shortlived effect known as the "cold dome." During the winter, the cold dome structure is masked by intrusions from the Kuroshio and the lack of horizontal temperature variations caused by seasonal atmospheric cooling. (Jan et al., 2011)

We now summarize the work of Jan et al. (2011). The cold dome is centered at $25.625^{\circ} \mathrm{N}, 122.125^{\circ} \mathrm{E}$, with a diameter of $100 \mathrm{~km}$. The average temperature at the center is $21^{\circ} \mathrm{C}$. In the region, the temperature standard deviation at $50 \mathrm{~m}$ is $2.5^{\circ} \mathrm{C}$, while in the cold dome the standard deviation is only $2^{\circ} \mathrm{C}$. At $100 \mathrm{~m}$, the cold dome has a standard deviation of $<1^{\circ} \mathrm{C}$. These small standard deviations indicate that the cold dome waters are sourced by upwelling from below $100 \mathrm{~m}$. ADCP data indicate a weak cyclonic flow at $50 \mathrm{~m}$, another sign of upwelling within the dome structure.

The oceanographic features of the region are impacted by many forcings, including atmospheric forcings (especially typhoons and monsoons), buoyancy forcing from freshwater river discharge, eddies, and water mass formation. The presence of smaller currents, wave propagation, and internal tides all contribute to a highly complex ocean environment that is challenging to predict (Gawarkiewicz et al., 2011). 


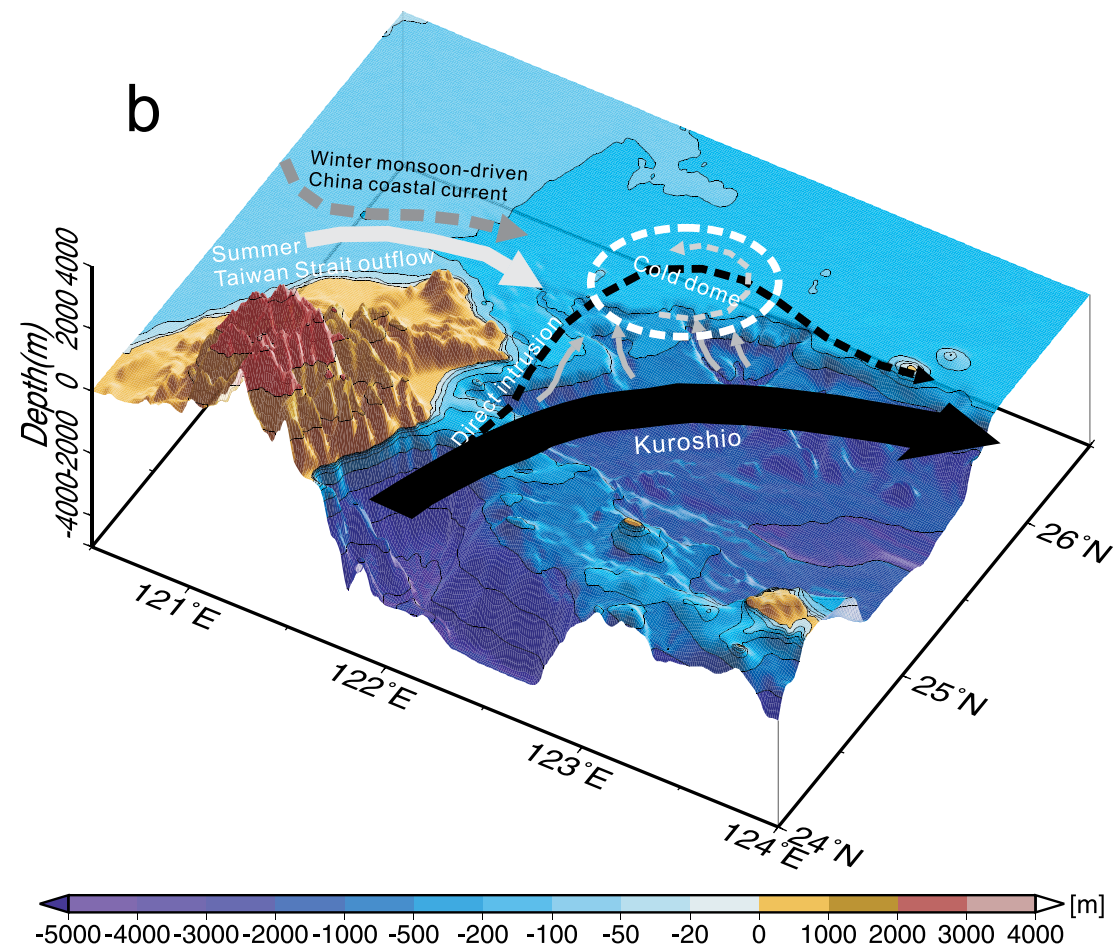

Figure 2-5: Three-dimensional rendering of cold dome formation. (Jan et al., 2011)

\subsection{Quantifying, Predicting, and Exploiting Uncer- tainty Department Research Initiative}

The Quantifying, Predicting, and Exploiting Uncertainty Department Research Initiative (QPE DRI) was undertaken in order to study the "wide variety of physical processes ocurring on a broad range of spatial and temporal scales" in the region surrounding Taiwan (Gawarkiewicz et al., 2011).

\subsubsection{Motivation for and Goals of the QPE DRI}

Model forecasts are crucial to the exploration and understanding of the ocean. However, model forecasts will inherently have some uncertainty, and being able to measure uncertainty is important to the users of model forecasts. This is especially important in a complex environment such as the ocean surrounding Taiwan.

The QPE DRI was a joint US-Taiwan program aimed at exploring uncertainty 
and forecasting in the highly dynamical and challenging environment around Taiwan. Led by Glen Gawarkiewicz of the Woods Hole Oceanographic Institution and Jan Sen

of the National Taiwan University, the program included participants from multiple organizations within the US and Taiwan, and was partially sponsored by the Office of Naval Research.

One of the goals of the QPE project was to better understand the complex dynamics of the region by combining model forecasts with in-situ observations and by performing sensitivity studies on existing models. By collecting data and carefully

processing it, we can gain an increased understanding of the ocean processes, as well as improved model forecasts. Uncertainty within model forecasts must be quantified in order for the model forecasts to be useful.

Other program goals, though not neccessarily discussed in this thesis, are to couple acoustic and environmental models with tides and nesting, research more effective ways to link small-scale and large-scale models, and use adaptive sampling techniques (Lermusiaux et al., 2010).

The late summer was chosen as the timeframe because the unique combination of the summer monsoon, typhoon frequency and cold dome formation provide ample opportunities to study the dynamic oceanography within the region (Gawarkiewicz et al., 2011).

\subsubsection{IOP Observation Plan}

The Intense Observation Period lasted from 18 August to 10 Septemeber 2009. Gliders were released into the Kuroshio in May 2009 by the US research vessel $R / V$ Roger Reville, and near surface drifters were released weekly in the leadup to the IOP. This method obtained observations for model initialization and later comparison.

From 13 - 17 August, eighty-eight Surface Velocity Program (SVP) drifters were deployed; the Taiwanese research vessels $R / V$ Ocean Researcher 2 (OR2) and $R / V$ Ocean Researcher 3 (OR3) launched half of these into the waters northeast of Taiwan in early August, and the $R / V$ Roger Reville launched the other half during the IOP (Gawarkiewicz et al., 2011). 


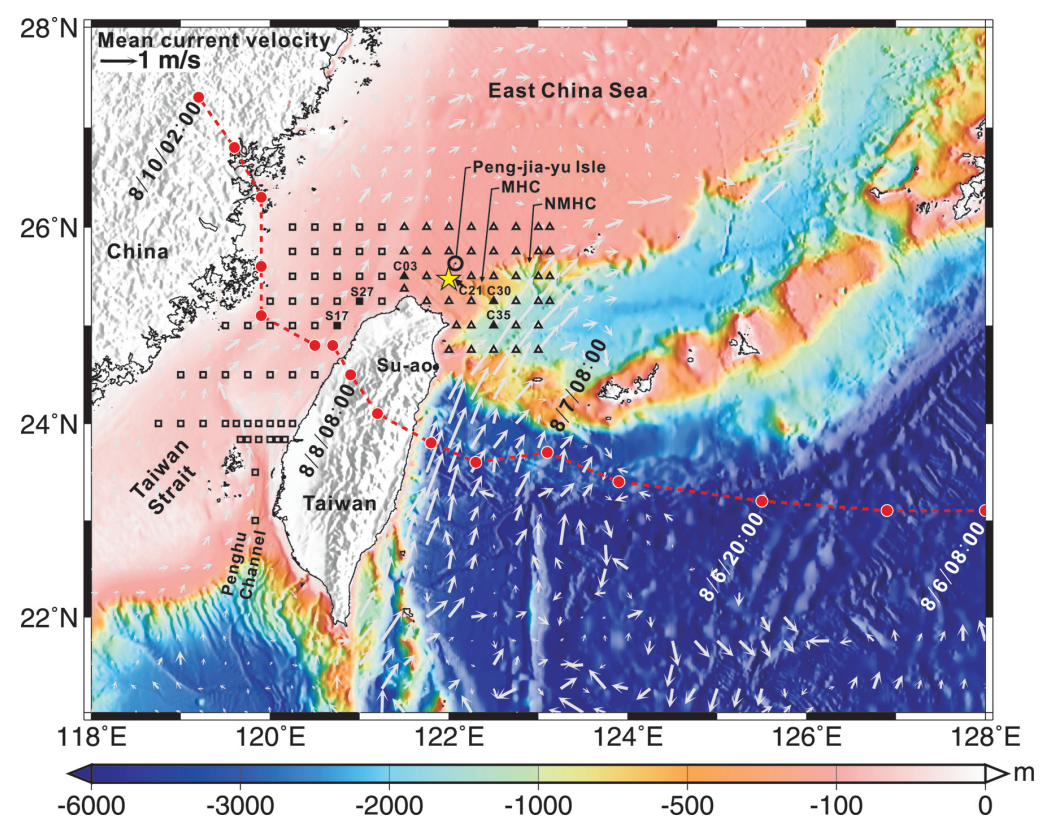

Figure 2-6: Map of observing plan for QPE IOP. Triangles indicate CTD drops of $R / V$ Ocean Researcher 2 (OR2) and squares indicate CTD drops of $R / V$ Ocean Researcher 3 (OR3). Yellow star is a biogeochemcial sampling station, and gray arrows show mean current velocity, taken from historical ADCP data. Red dashed line shows the track of Typhoon Morakot. (Jan et al., 2013)

The OR2 and OR3 also took measurments via Conductivity-Temperature-Depth sensors (CTD) and Acoustic Doppler Current Profilers (ADCP) during this period, and again from 21 - 27 August and 27 August - 2 September (Jan et al., 2013). The locations for these profiles are shown in Figure 2-6.

Two SeaSoar surveys near mooring arrays to the east of Taiwan and profiler floats over the continental shelf provided high-resolution measurements. SeaSoar is a towed vehicle that can undulate, allowing an oceanographic profile to be measured approximately every $3 \mathrm{~km}$ (Woods Hole Oceanographic Institution, 2014).

Bottom-mounted ADCPs and CTDs were also used in the continental shelf region and the North Mien-Hua Canyon (labeled NMHC in Figure 2-6) (Gawarkiewicz et al., 2011).

During the IOP, the Multidisciplinary Simulation, Estimation and Assimilation Systems (MSEAS) model simulations were run 10 - 30 times daily, incorporating new data into the model almost as soon as it was collected (Haley et al., 2014). The 
real-time updates allowed adaptive sampling plans to be utilized for both physical and acoustic sampling. This meant the sampling plan could be guided by the model forecasts, and allowed the model forecast uncertainties to be improved by utilizing the best possible sampling plan.

\subsection{MSEAS Primitive-Equation Ocean Model}

The goal of the MSEAS primitive-equation ocean model is to produce accurate and timely regional ocean forecasts, accounting for tidal-to-mesoscale oceanic processes. The model specializes in regions with complex and varied topography. It is capable of implicit two-way nesting, resolving multiscale hydrostatic primitive equations with a nonlinear free surface, or high-order finite element code on unstructured grids for non-hydrostatic processes (Haley et al., 2014).

The MSEAS family of models includes initialization schemes, nested data-assimilative tidal prediction and inversion; fast-marching coastal objective analysis; stochastic subgrid-scale models; generalized adaptable biogeochemical modeling system; Lagrangian Coherent Structures; non-Gaussian data assimilation and adaptive sampling; dynamically-orthogonal equations for uncertainty predictions; and machine learning of model formulations (Haley et al., 2014).

We summarize, from Haley and Lermusiaux (2010), the primitive equations used in the MSEAS ocean model. These are derived from the Navier-Stokes equations and assume hydrostatic and Boussinesq approximations.

$$
\begin{aligned}
\text { Cons. Mass } & \nabla \cdot \vec{u}+\frac{\partial w}{\partial z}=0 \\
\text { Cons. Horiz. Mom. } & \frac{D \vec{u}}{D t}+f \hat{k} \times \vec{u}=-\frac{1}{\rho_{0}} \nabla p+\vec{F}, \\
\text { Cons. Vert. Mom. } & \frac{\partial p}{\partial z}=-\rho g, \\
\text { Cons. Heat } & \frac{D T}{D t}=F^{T}, \\
\text { Cons. Salt } & \frac{D S}{D t}=F^{S}, \\
\text { Eq. of State } & \rho=\rho(z, T, S),
\end{aligned}
$$




$$
\text { Eq. FreeSurface } \quad \frac{\partial \eta}{\partial t}+\nabla \cdot\left(\int_{-H}^{\eta} \vec{u} d z\right)=0
$$

As noted in Haley and Lermusiaux (2010), the state variables are the horizontal and vertical components of velocity $(\vec{u}, w)$, the temperature, $T$, and the salinity $S$. The $\frac{D}{D t}$ is the $3 \mathrm{D}$ material derivative, $p$ is the pressure, $f$ is the Coriolis parameter, $\rho$ is the density, $\rho_{0}$ is the (constant) density from a reference state, $g$ is the acceleration due to gravity and $\hat{k}$ is the unit direction vector in the vertical direction. The gradient operators, $\nabla$, in Equations 2.1 and 2.2 are two dimensional (horizontal) operators. The turbulent sub-gridscale processes are represented by $\vec{F}, F^{T}$ and $F^{S}$. Finally, the surface elevation is $\eta$ and $H=H(x, y)$ is the local water depth in the undisturbed ocean.

For the equations governing the numerical methods, as well as the numerical discretizations utilized in the model, see Haley and Lermusiaux (2010, Sect. 2.1 and $2.2)$.

\subsection{Typhoon Morakot}

Typhoon Morakot was a Category I typhoon that affected Taiwan and the surrounding region in early August, 2009.

\subsubsection{Typhoon Morakot Overview}

Typhoon Morakot developed over the Philippine Sea on 04 August 2009 and intensified into a typhoon by the next day as it tracked westward. Morakot had maximum sustained winds of $80 \mathrm{kts}$, making it a Category I typhoon (Joint Typhoon Warning Center, 2009) as it approached Taiwan at a speed of about $11 \mathrm{kts}$ (20 km/hr) (Jan et al., 2013). The storm spread for a diameter of more than 1,000 miles $(1700 \mathrm{~km})$ (Gutro, 2009). The size of the storm is shown in Figure 2-7. The storm eye moved over Taiwan just before 1800Z on 07 August 2009 (Joint Typhoon Warning Center, 2009) and interaction with Taiwan's rugged topography caused its speed to decrease by half (Jan et al., 2013). The storm eye moved offshore towards China before 0600Z 


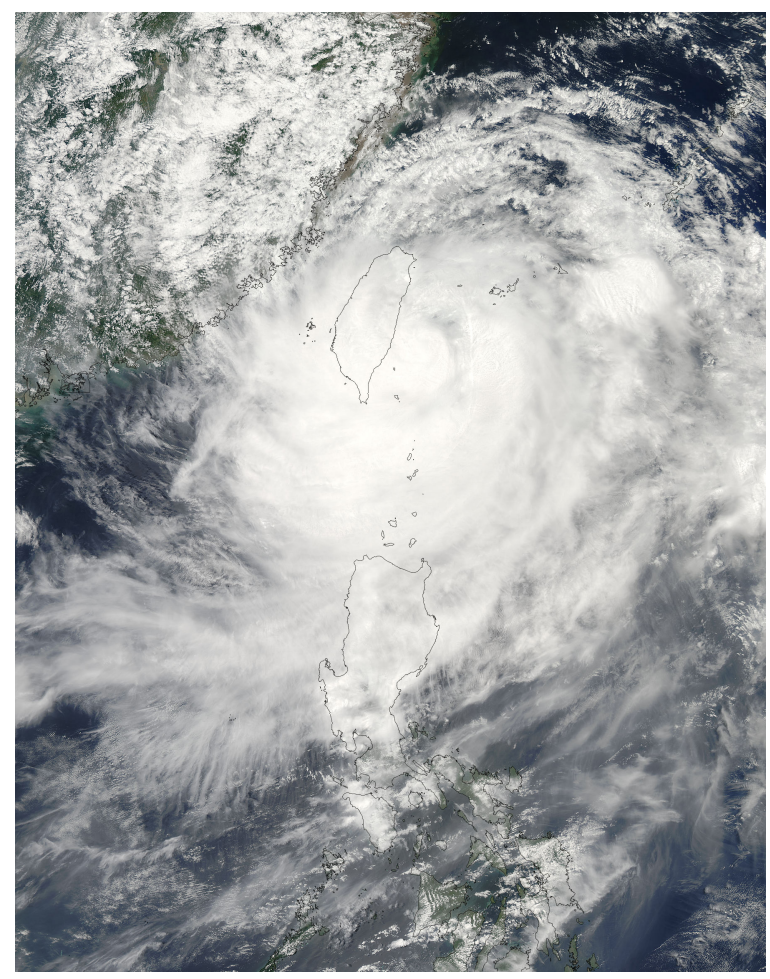

Figure 2-7: Satellite image of Typhoon Morakot on 06 August 2009 at 0525Z, taken by Moderate Resolution Imaging Spectroradiometer (MODIS) aboard the NASA Aqua satellite. (NASA/MODIS Rapid Response, 2009)

on 08 August.

\subsubsection{Precipitation from Typhoon Morakot}

The storm center passed over the island in less than twelve hours; however, the slow speed, immense span, and intake of moisture combined for the highest rainfall totals in Taiwan in 50 years. NASA's Tropical Rainfall Measuring Mission satellites showed nearly half the island received more than $600 \mathrm{~mm}$ during 03 - 10 August 2009, and some areas showed rainfall totals of greater than $1000 \mathrm{~mm}$ (40 inches) (Lang, 2009). These estimates are lower than those of the Taiwan Central Geological Survey, which had high-precision instruments with in-situ measurements throughout the period. Their measurements show a large portion of southern Taiwan received in excess of $2.0 \mathrm{~m}$ of rainfall, with some areas receiving $2.6 \mathrm{~m}$ over the period of the storm. See Figure 2-8. 


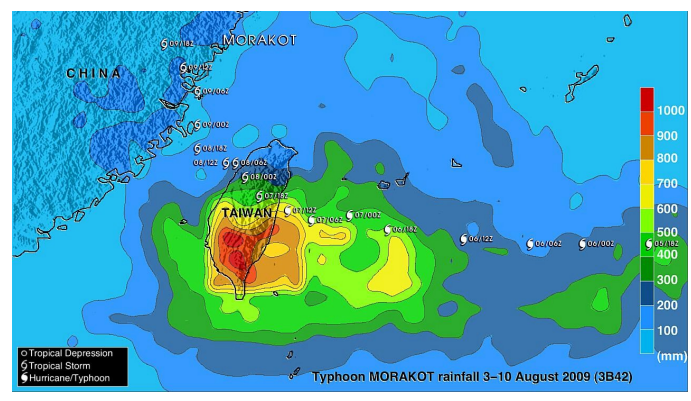

(a)

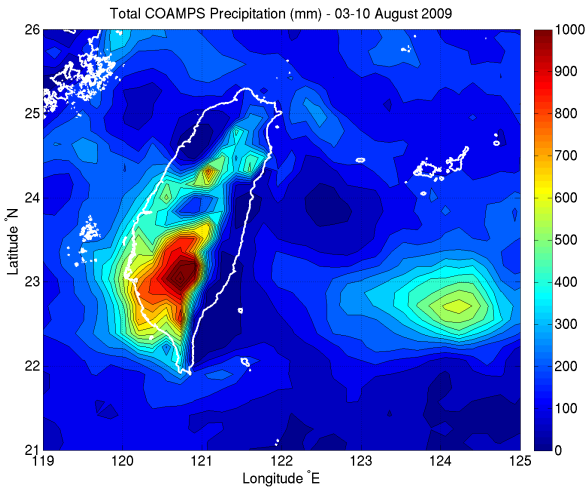

(b)

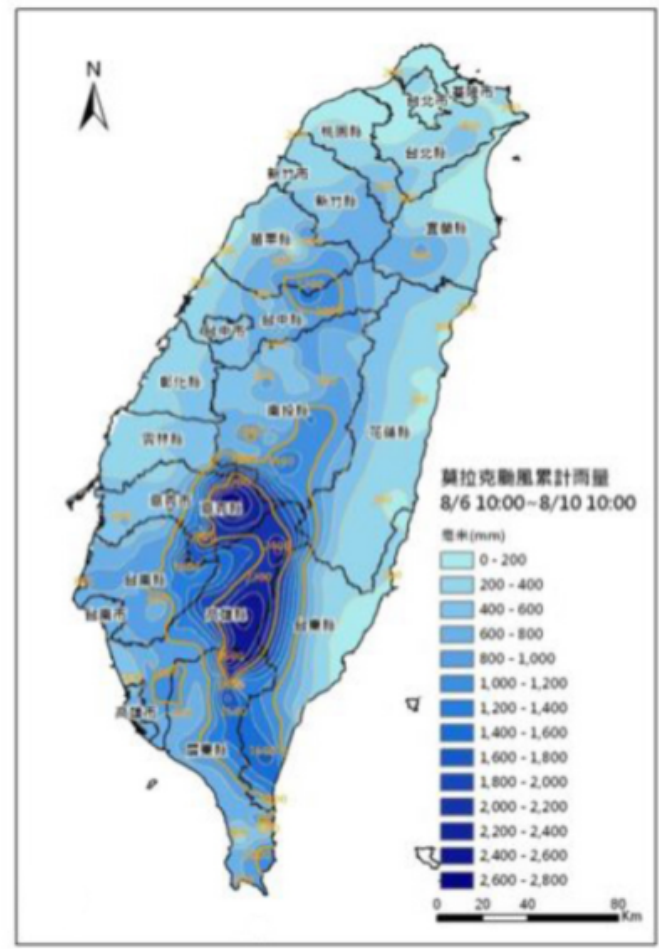

(c)

Figure 2-8: Precipitation estimates for rainfall associated with Typhoon Morakot obtained from (a) NASA's Tropical Rainfall Measuring Mission satellites (SSAI/NASA, Hal Pierce, 2009), (b) nowcast from the NRL's Coupled Ocean/Atmosphere Mesoscale Prediction System (COAMPS) (Naval Research Laboratory, 2012), and (c) the Taiwan Central Geologial Survey in-situ measurements (Liu, 2010). 
The abnormally high rainfall contributed to mudslides and severe flooding (Lang, 2009). Taiwan's rivers, unable to absorb the excess precipitation, showed record discharge rates, peaking 6 - 10 August.

The typhoon had devastating consequences to the island of Taiwan, as well as mainland China. For oceanographic research, the timing of the storm allowed for a rare opportunity to compare oceanographic data before and after the passage of a typhoon.

\subsection{River Discharge Model}

The unprecedented amount of precipitation was unable to be absorbed by the terrain. Due to lack of time and personnel during the DRI, the river runoff from the flooded rivers was not incorporated into the real-time MSEAS ocean model. However, the freshwater river discharge must be accounted for in ocean models to accurately forecast oceanographic variables, including salinity. Ocean models use forecasts from atmopsheric models, but in this case, precipitation was underforecast, so the direct impact on the ocean's properties could not be accurately represented. Nonetheless, the majority of the freshwater input was later found to come from the river discharges, in part because of the higher level clouds encountering the mountain range (see Section 2.1). To properly input the river component of this additional freshwater source, a river discharge model was created (Mirabito et al., 2012). The following is a summary of the development of the river discharge model; for the more detailed explanation of the model, we refer to the original description by Mirabito et al. (2012).

\subsubsection{River Discharge Model Concept}

A control volume is defined such that precipitation enters the grid box through the top boundary. Some loss due to soil absorption and collection in reservoirs occurs at the bottom boundary. All other precipitation leaves via lateral boundaries as freshwater river discharge (see Figure 2-9). Defining the control volume as $\Omega$ with a boundary $\partial \Omega$, and using the traditional notation of $\rho$ for rainwater density in $\mathrm{kg} / \mathrm{m}^{3}$ and $\vec{u}$ for 


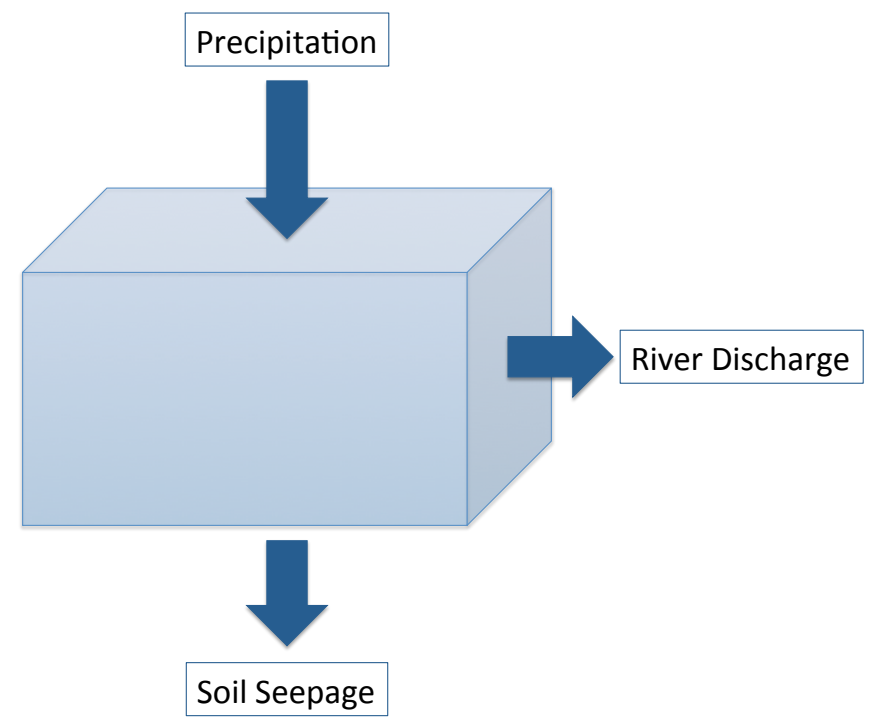

Figure 2-9: Schematic of river discharge model control volume.

flow velocity in $\mathrm{m} / \mathrm{s}$, it is shown that:

$$
\int_{\Omega} \frac{\partial \rho}{\partial t} d \Omega+\int_{\partial \Omega} \rho \vec{u} \cdot \vec{n} d A=0
$$

Assuming incompressible rainwater with constant temperature and salinity allows the first term in Equation 2.8 to become 0. The second term is expanded to each side of the control volume.

$$
\int_{\partial \Omega} \rho \vec{u} \cdot \vec{n} d A=-\dot{Q}_{p}+\sum_{i} \dot{Q}_{i}+\dot{Q}_{s}=0
$$

where $\dot{Q}_{p}$ is the precipitation rate $\left(\mathrm{m}^{3} / \mathrm{s}\right), \dot{Q}_{i}$ is the total discharge rate $\left(\mathrm{m}^{3} / \mathrm{s}\right)$ at river mouth $i$, and $\dot{Q}_{s}$ is the total seepage rate $\left(\mathrm{m}^{3} / \mathrm{s}\right)$. Evaporation is neglected in Equation 2.9. The river discharge model assumes that some of the rainfall will be absorbed into the soil or collect in lakes and reservoirs. For simplicity, this is assumed to be a constant fraction, neglecting changes in terrain and soil properties. Per estimates from the National Taiwan Normal University, one-third of the rainfall is assumed to be lost to soil seepage, irrigation or collection in natural lakes and reservoirs, such that $\dot{Q}_{s}=\alpha \dot{Q}_{p}$ where $\alpha=\frac{1}{3}$. Using $\dot{Q}_{i}$ to represent the total river 
discharge for one river $i$ during the period:

$$
\sum_{i} \dot{Q}_{i}=(1-\alpha) \dot{Q}_{p}
$$

To apply this concept to the MSEAS ocean model, the freshwater source is modeled as a salinity sink. A low-salinity input is applied to selected gridpoints near the river mouth. The execution is more complicated, due to the complexity of the involved processes and the lack of data.

\subsubsection{Precipitation Estimation and Drainage Basins}

The data for rainfall during the period of heaviest rainfall, 6 - 10 August 2009, provided in Figure 2-8 provides total precipitation amounts, but not precipitation rates. The island was divided into four drainage basins, with boundaries based on information from the Water Resources Management Research Center at the National Taiwan Ocean University. The total precipitation for each basin, denoted $Q_{p, j}$, was estimated from Figure 2-8(c). Applying Equation 2.10 provides a total discharge amount per basin over the period:

$$
Q_{j}=(1-\alpha) Q_{p, j}
$$

where the index $j$ indicates the drainage basin.

Now that Mirabito et al. (2012) have estimated for the discharge per basin, the next step is to compute the discharge associated with each of the major rivers. Taiwan has 129 rivers, and twenty-one major rivers. Only eleven had readily available, reliable annual mean discharge data; these rivers account for $53 \%$ of the total river discharge of Taiwan, and will be used in the model to represent $100 \%$ of the drainage from Morakot. See Figure 2-10. These eleven rivers were each assigned to a drainage basin based on their geography. Using the annual mean discharge rate for each river, a weighting factor $\beta_{i}$ can be computed for each river $i$, which gives an approximation of the distribution of discharge within the basin. This allows the total discharge amount per basin $Q_{j}$ to be divided appropriately among the rivers within Basin $j$. 


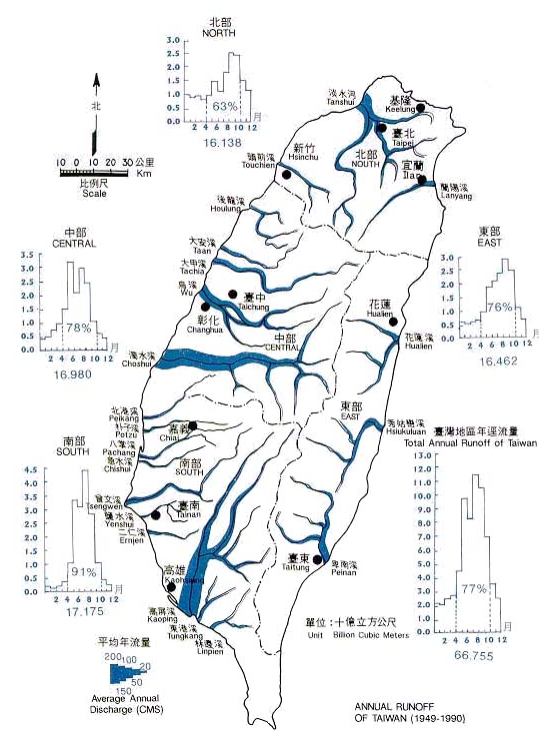

(a)

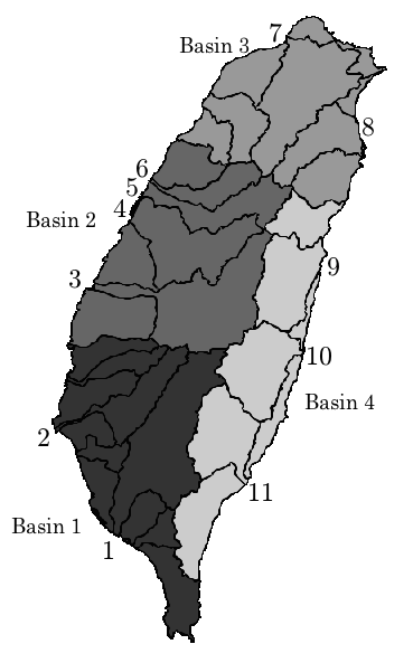

(b)

Figure 2-10: Figures used in estimation of individual river discharge. (a) Map of major rivers of Taiwan. (b) Watersheds in Taiwan and model discharge basin boundaries. Numbers indicate mouths of major rivers, while shading indicates River Discharge Model drainage basins. (Mirabito et al., 2012)

In the following equation, $n_{j}$ represents the total number of rivers assigned to basin $j$.

$$
Q_{j}=\sum_{i=1}^{n_{j}} \beta_{i} Q_{i} \quad \text { or } \quad Q_{i}=\frac{Q_{j}}{\beta} .
$$

\subsubsection{Time Dependency of River Discharge}

As discussed above, the data lends itself to computations of discharge amounts, but it would be physically unrealistic to input the full discharge amount into the ocean model over a single time instant. Rather, a discharge rate must be computed in order to realistically simulate the addition of the freshwater discharge into the ocean. Thus, an average discharge rate, denoted $\bar{Q}_{j}$, can be computed for each basin by taking the integral over the time period, with $t_{0}$ representing the start of our data at $0000 \mathrm{Z}$ on 6 August and $T$ representing the 96 hours over which the heaviest rainfall occurred: 


\begin{tabular}{|c|c|c|c|c|}
\hline $\begin{array}{l}\text { Basin } \\
\text { Index }(\mathrm{j})\end{array}$ & $\begin{array}{l}\text { River } \\
\text { Index (i) }\end{array}$ & $\begin{array}{l}\text { River Name } \\
\text { Discharge }\left(\mathrm{m}^{3} / \mathrm{s}\right)\end{array}$ & Annual Mean & $\beta_{i}$ \\
\hline \multirow[t]{2}{*}{1} & 1 & Gāopíng (高屏) & 220 & 0.81 \\
\hline & 2 & Zēngwén (曾文) & 50 & 0.19 \\
\hline \multirow[t]{4}{*}{2} & 3 & Zhuóshuǐ (濁水) & 210 & 0.51 \\
\hline & 4 & Wū (鳥) & 120 & 0.29 \\
\hline & 5 & Dàjiă (大甲) & 50 & 0.12 \\
\hline & 6 & Dàān (大安) & 35 & 0.08 \\
\hline \multirow[t]{2}{*}{3} & 7 & Dànshuǐ (淡水) & 200 & 0.80 \\
\hline & 8 & Lányáng (蘭陽) & 50 & 0.20 \\
\hline \multirow[t]{3}{*}{4} & 9 & Huālián (花蓮) & 60 & 0.31 \\
\hline & 10 & Xiùgūluán (秀姑巒) & 55 & 0.28 \\
\hline & 11 & Bēinán (卑南) & 80 & 0.41 \\
\hline
\end{tabular}

Table 2.1: The eleven rivers of Taiwan used in the river discharge model and their assigned drainage basin. The relative strength of the annual mean discharge of each river within its basin determines the discharge weight $\beta_{i}$. (Mirabito et al., 2012)

$$
\begin{array}{ll}
\bar{Q}_{1}=13000 \mathrm{~m}^{3} / \mathrm{s} & \bar{Q}_{3}=3500 \mathrm{~m}^{3} / \mathrm{s} \\
\bar{Q}_{2}=10000 \mathrm{~m}^{3} / \mathrm{s} & \bar{Q}_{4}=6300 \mathrm{~m}^{3} / \mathrm{s}
\end{array}
$$

Table 2.2: Average Discharge Rate by Basin. (Mirabito et al., 2012)

$$
\bar{Q}_{i} \stackrel{\text { def }}{=} \frac{1}{T} \int_{t_{0}}^{t_{0}+T} \bar{Q}_{i} d t, \quad i \in\{1,2, \ldots, 11\}
$$

This results in an average discharge rate per river for the period of heaviest rainfall during Typhoon Morakot. While more reasonable than inputting the entire discharge amount at once, this rate is still not the best physical representation, as the actual discharge rate will fluctuate highly during this time period.

In order to best represent the freshwater discharge rate throughout the typhoon, Mirabito et al. (2012) uses a time-dependent scaling factor $\lambda_{i}$ which must be computed for each river $i$ such that the best representation of the discharge rate per river $\dot{Q}_{i}$ can be modeled:

$$
\dot{Q}_{i}=\lambda_{i} \dot{Q}_{r e f} \quad i \in\{1,2, \ldots, 11\} .
$$


In-situ measurements of river discharge were available throughout the period for only two of the above rivers; the Zhuóshuǐ River (index $i=3$ ) had readings taken approximately every 7.5 hours, and the Gāopíng River (index $i=1$ ) had daily readings. These are, in terms of annual mean discharge, the largest two rivers on Taiwan. The data covered the period from 1 August to 15 September 2009. Mirabito et al. (2012) used this data to represent the average normalized discharge rate for each river.

The known discharge rate data, denoted $\dot{Q}_{Z}$ and $\dot{Q}_{G}$, respectively, was extrapolated so each had the same timescale. It was then normalized to account for differences in discharge quantity, and the average of the two series was taken, denoted $\left|\dot{Q}_{r e f}\right|$. This average can then be used to represent the time series for discharge rates for the other nine rivers.

$$
\dot{Q}_{r e f}=\frac{1}{2}\left(\frac{\dot{Q}_{G}}{V_{G}}+\frac{\dot{Q}_{Z}}{V_{Z}}\right),
$$

where

$$
V_{G}=\int_{t_{0}^{*}}^{t_{0}^{*}+T^{*}} \dot{Q}_{G} d t
$$

with $t_{0}^{*}$ representing 0600Z 1 August and $T^{*}$ representing 45 days, the length of the data set for $\dot{Q}_{Z}$ and $\dot{Q}_{G}$.

It can be shown that the period of heaviest rainfall, lasting 96 hours, accounts for $67.34 \%$ of the total rainfall during the 45 -day period represented by $\dot{Q}_{r e f}$ :

$$
\int_{t_{0}}^{t_{0}+T} \dot{Q}_{r e f} d t \approx 0.6734
$$

which allows computation of the scalar quantity $\lambda_{i}$ via

$$
\begin{aligned}
\int_{t_{0}}^{t_{0}+T} \dot{Q}_{r e f} d t & =\frac{0.6734}{T \beta_{i} \bar{Q}_{i}} \int_{t_{0}}^{t_{0}+T} \dot{Q}_{i} d t \\
\lambda_{i} & =\frac{T \beta_{i} \bar{Q}_{j}}{0.6734} .
\end{aligned}
$$

Now the average discharge rate $\bar{Q}_{i}$ can be multiplied by the normalized time series to determine how much freshwater discharge to apply to each timestep in the model. 

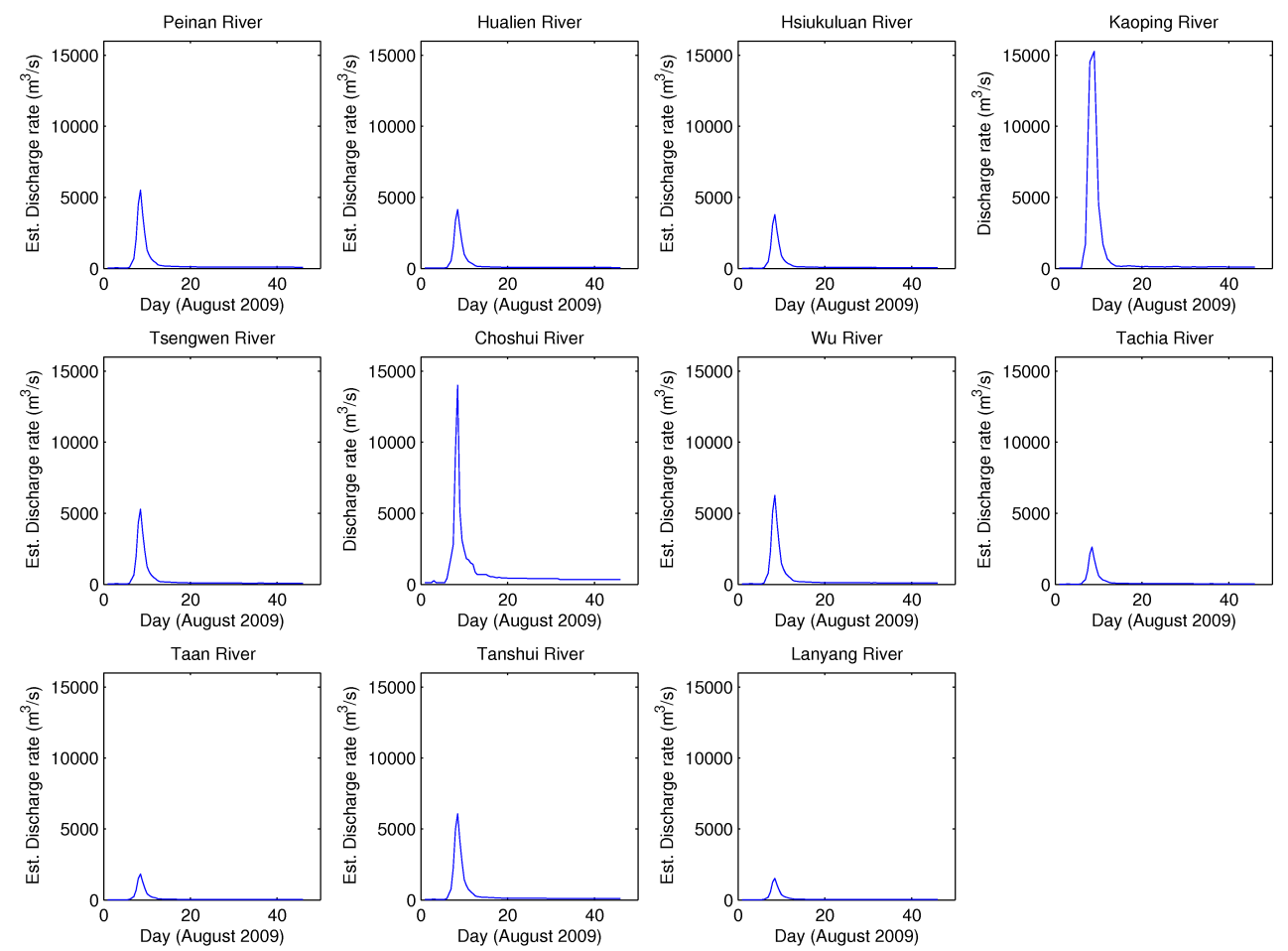

Figure 2-11: Discharge rates for each river as computed by this method, with the actual data replacing the time series for the Zhuóshuř and Gāopíng Rivers. (Mirabito et al., 2012)

The actual time series replaced the averaged time series for the Zhuóshuř and Gāopíng Rivers to increase accuracy. Figure 2-11 shows the discharge rates for each river as computed by this method, with the actual data replacing the time series for the Zhuoshui and Gaoping Rivers.

The river discharge model of Mirabito et al. (2012) is now able to provide a salinity sink of appropriate size and time series to model the freshwater discharge.

\subsubsection{Forcing the MSEAS Ocean Model with the River Dis- charge Model}

In the original work of Mirabito et al. (2012), the modeled river discharge was applied to the ocean model simulations using a salinity relaxation factor in the finite-volume grid boxes nearest to the respective river mouth. For the initial tests, the size of the grid footprint was limited to seven grid cells and the salinity relaxation was applied to 
a depth of $10 \mathrm{~m}$. The river discharge computed by the above methods was distributed evenly throughout these seven gridpoints and throughout the depth.

\subsection{Preliminary Results of the Original River Dis- charge Model}

When applied to the MSEAS ocean model, near-shore salinity was significantly improved during and after typhoon passage, more closely matching the data collected during the QPE experiment. In Figure 2-12, the impact of the river discharge model on forecasted salinity is obvious. Several areas of improvement were identified and will be addressed in Section 3.2. 


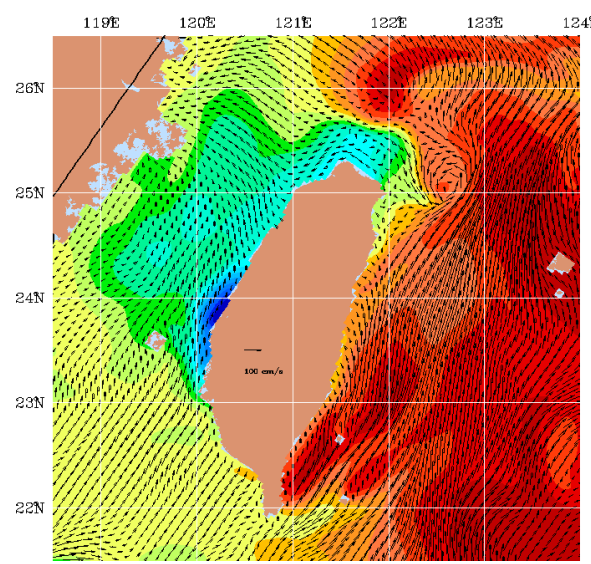

(a) August 09

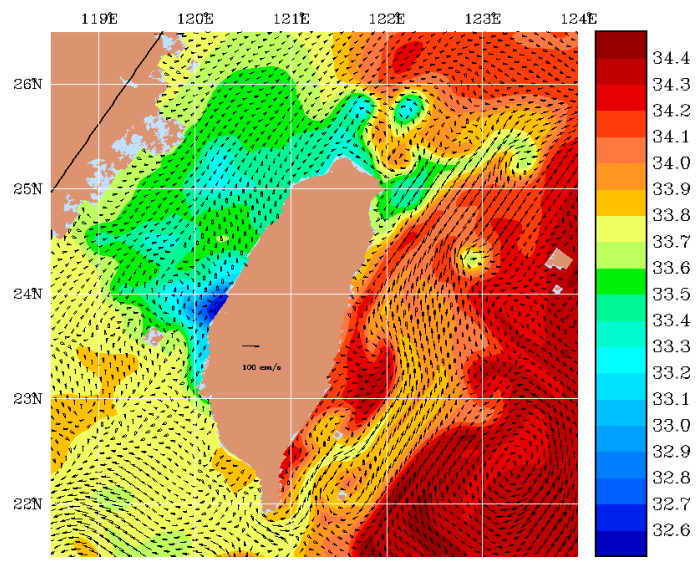

(c) August 17

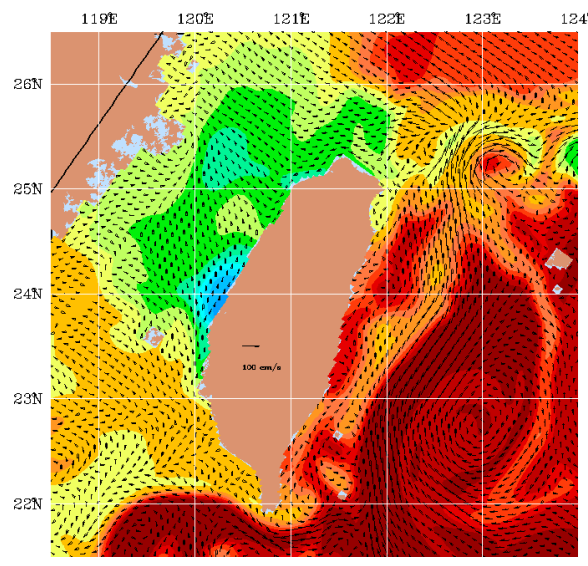

(e) August 19

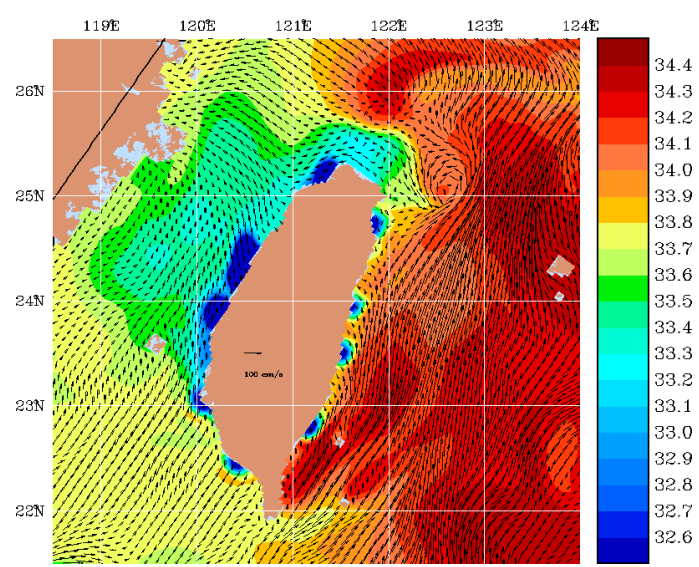

(b) August 09 - with river

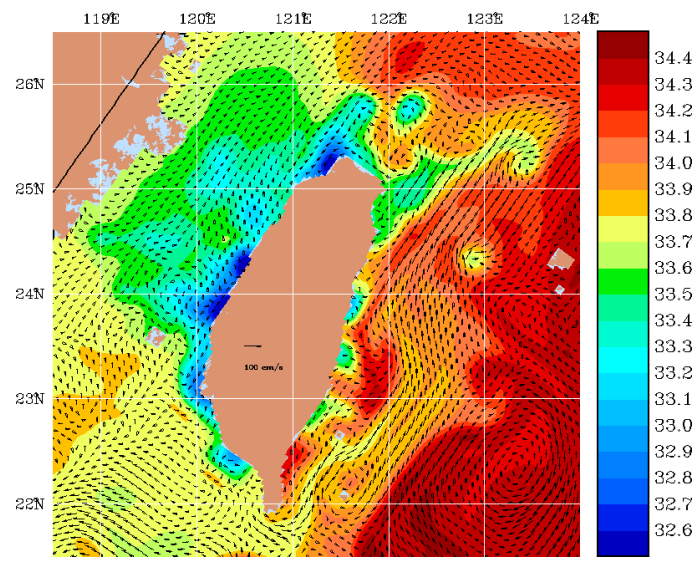

(d) August 17 - with river

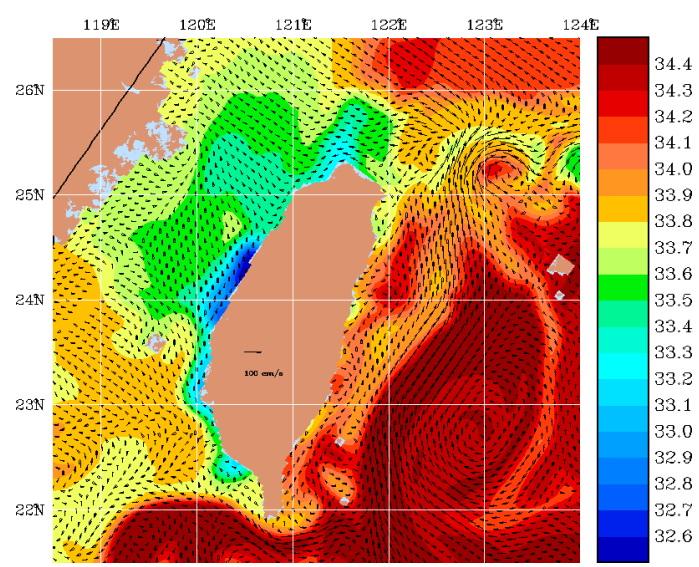

(f) August 25 - with river

Figure 2-12: Surface salinities forecast by the MSEAS ocean model with no river forcing (left column) and with river discharge model (right column). (Mirabito et al., 2012) 
THIS PAGE INTENTIONALLY LEFT BLANK 


\section{Chapter 3}

\section{Methods}

In this chapter, we discuss the different approaches to improving the river discharge model and the bulk mixing model. The chapter begins with a discussion and derivation of the salinity forcing equation, then moves on to specific areas of the models that were explored for possible improvement. These improvements have the benefit of hindsight, but incorporating these changes into future use will enable enhanced forecasting.

\subsection{Bulk Mixing Model of River and Ocean Waters}

The river discharge model and freshwater flow-rate estimates provided in Section 2.5 need to be applied as a forcing to the ocean model. The subsequent mixing of river and ocean waters is discussed in this section where we derive a simple mixing model.

Normally, the river water enter the ocean in river mouths and estuaries, possibly with hydraulic jumps and a river head differential, usually forming small-scale plumes, vertical billows with instabilities such as Kelvin-Helmoltz instabilities and overall turbulent structures in these river mouths and estuaries (Özgökmen and Chassignet, 2002). Subsequently, complex advection pattern and additional eddy and turbulent mixing occur.

In this section, we will represent all of these processes in the vicinity of the river mouths as a bulk volume mixing of input fresh riverwater with the local ocean water, 
provided at a rate proportional to the local river discharge considered. This local mixing is modeled as a source, or forcing, of lower salinity river water that is input to the selected local ocean volume (specified by an ocean area and depth range near the river mouth). That given local ocean volume is itself discretized by the set of finite-volumes in the MSEAS ocean model, and the freshwater river water is provided in each of these finite-volume cells, usually at a rate equally distributed to each of these finite-volume cells.

Next, we provide the derivation of this lower salinity source or forcing function. Then we look at possible areas of improvement in the original model, then explore these potential improvements.

\subsubsection{Derivation of Salinity Forcing Function}

Here we consider a local ocean finite-volume $\mathrm{V}$ selected near the mouth of a given river $\mathrm{R}$. This volume, affected by the fresh water river forcing, is specified by an ocean area and depth range near the coast, in accordance with the expected ocean currents in the region. We assume that a source, or forcing, of lower salinity river water is input to this selected local ocean volume. In Figure 3-1, we sketch such a volume, both without and with the fresh water river discharge. In our notation, we define the mass flow rate of salt to be $\dot{m}_{S}=S \cdot \dot{Q}$ where $S$ is the salinity concentration in $\mathrm{kg} / \mathrm{m}^{3}$ and $\dot{Q}$ is the flow rate of the water in $\mathrm{m}^{3} / \mathrm{s}$.

We begin by applying the conservation of mass of salt to the considered finitevolume $\mathrm{V}$. We obtain, using conservation in the summation form,

$$
\frac{d}{d t} M_{S}=\sum \dot{m}_{S, \text { in }}-\sum \dot{m}_{S, \text { out }} .
$$

We then rewrite the equation in terms of the definitions above to be

$$
\frac{d}{d t} M_{S}=\sum(S \dot{Q})_{i n}-\sum(S \dot{Q})_{o u t} .
$$

Consider a control volume, or grid cell, with no river discharge model. In this case, 
the only salt fluxes are the flux into and the flux out of the cell via normal ocean processes.

$$
\frac{d}{d t}\left(M_{S}\right)=S_{\text {in }} \dot{Q}_{\text {in }}-S_{\text {out }} \dot{Q}_{\text {out }}
$$

If we now consider the conservation of mass of water, assuming incompressibility at first order, i.e. div $u=0$ in a Boussinesq fluid (Cushman-Roisin and Beckers, 2011), and neglecting the volume variations due to the free surface (Haley and Lermusiaux, 2010), we obtain conservation of volume of ocean water, i.e.

$$
\dot{Q}_{\text {in }}+\dot{Q}_{\text {out }}=0
$$

With these two relations in Equations 3.3 and 3.4, we now consider the the "bulk mixing" model of river and ocean waters, adding freshwater discharge from a given river with salinity concentration $S_{R}$ at river discharge rate $\dot{Q}_{R}$ into the into the considered finite-volume cell, which gives an additional salinity flux into the box of $S_{R} \dot{Q}_{R}$, as illustrated in Figure 3-1(b). Next, we re-apply the conservation of water (volume) and of salt to this new situation.

Starting first with conservation of volume (water mass), since the water mass flow rate into and out of the cell must still be equal (the incompressibility and neglected free-surface principle utilized to obtain Equation 3.4 still apply), we have $\dot{Q}_{R}$ of additional water entering and also leaving the finite-volume $\mathrm{V}$.

However, considering the salt conservation, we also have a new salinity flux out of the cell, denoted $S \dot{Q}_{R}$. This $S$ is defined as the average salinity concentration of the entire finite-volume $\mathrm{V}$ and is different from $S_{\text {in }}$ and $S_{\text {out }}$. This $S$ represents the fully mixed salinity concentration within the cell. If the control volume becomes infinitesimally small, then the salinity concentrations become equal such that $S_{i n}=$ $S_{\text {out }}=S$. Using the average salinity concentration $S$ models the exit of well-mixed salinity in the control volume.

We now further define the mass of salt in the numerical finite-volume $\mathrm{V}$ as $M_{S}=$ $S \cdot V$. We can then simplify the left-hand side for a constant numerical finite-volume 


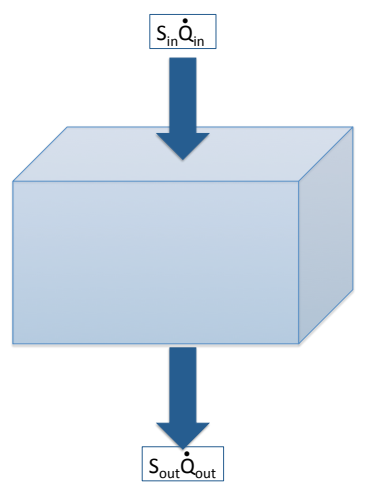

(a)

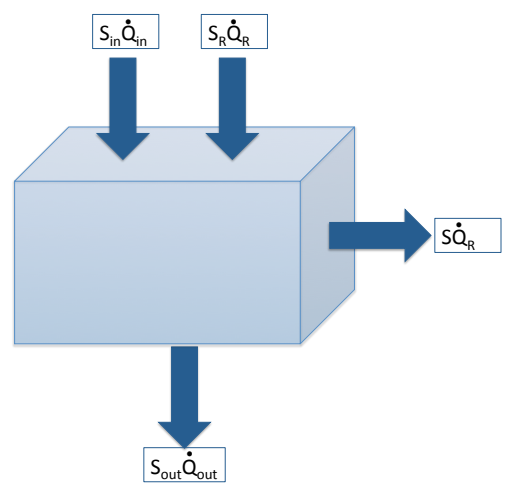

(b)

Figure 3-1: Diagram of salinity fluxes into and out of the control volume for (a) a model without freshwater discharge and (b) a model with freshwater discharge added.

$\mathrm{V}:$

$$
\frac{d}{d t}\left(M_{S}\right)=\frac{d}{d t}(S V)=V \cdot \frac{d S}{d t}
$$

and expand Equation 3.1 to include all four salt fluxes, to get

$$
V \frac{d S}{d t}=S_{i n} \dot{Q}_{i n}+S_{R} \dot{Q}_{R}-S_{\text {out }} \dot{Q}_{\text {out }}-S \dot{Q}_{R}
$$

Now we can group terms with the same flow rate, recalling Equation 3.4

$$
\frac{d S}{d t}=\left(S_{R}-S\right) \frac{\dot{Q}_{R}}{V}+\left(S_{\text {in }}-S_{\text {out }}\right) \frac{\dot{Q}_{\text {out }}}{V}
$$

The first term in that final equation $\left(S_{R}-S\right) \frac{\dot{Q}_{R}}{V}$ provides the additional rate of change in salinity that locally forces each finite-volume that is part of the coastal volume over which the bulk river mixing is applied. The left hand-side $\frac{d S}{d t}$ represents the timerate-of-change processes that affect salinity in that finite-volume and the last term $\left(S_{\text {in }}-S_{\text {out }}\right) \frac{\dot{Q}_{\text {out }}}{V}$ represents the sum of all in and out fluxes that were here modeled as bulk terms. When the control volume becomes infinitesimal, this last term becomes the sum of advective and diffusive salinity fluxes; the first term, $\frac{d S}{d t}$, becomes a partial derivative with respect to time; and the additional river forcing term remains as is, i.e. $\left(S_{R}-S\right) \frac{\dot{Q}_{R}}{V}$ excepted that $\frac{\dot{Q}_{R}}{V}$ becomes the local mass flux of river water (at a 
point in the coastal ocean).

From the above Equation 3.7, one then needs to distribute a priori where the river water is discharged in the coastal volume over which the bulk river mixing is applied; essentially, how to assign $\frac{\dot{Q}_{R}}{V}$ in space. To do so, if we assume, for now, that each finite-volume in that coastal volume receives the same amount of river water (the river water is equally distributed to each finite-volume), and that all finite-volumes have the same volume, then that total coastal volume over which the bulk river mixing is applied is Volume $=N V$ where $\mathrm{N}$ is the number of finite-volume cells used (per river), and $\mathrm{V}$ is still the volume of each finite-volume cell. The mass of salt in that total volume is then $M_{S}=S \cdot$ Volume. In that case, the above equation becomes

$$
\frac{d S}{d t}=\left(S_{R}-S\right) \frac{\dot{Q}_{R}}{N V}+\left(S_{\text {in }}-S_{\text {out }}\right) \frac{\dot{Q}_{\text {out }}}{N V}
$$

where $\dot{Q}_{R}$ is now the total river discharge and $\dot{Q}_{\text {out }}$ is the total advection flux. Of course, each finite-volume cell does not have the same volume. In our actual discrete model, the river water is distributed according to the horizontal footprint of these finite-volumes, which are all the same in the present MSEAS configuration (Haley and Lermusiaux, 2010).

If we ignore, for now, this "surface-based distribution of river waters" and work with the global Equation 3.8, we can utilize the Mirabito et al. (2012) definition for $\tau$ :

$$
\tau=\frac{N V}{\dot{Q}}
$$

we can rewrite the total fresh-water river forcing $\left(S_{R}-S\right) \frac{\dot{Q}_{R}}{N V}$ (to be applied locally on each finite-volume if that forcing is equally distributed in horizontal space) as

$$
\frac{\left(S_{R}-S\right)}{\tau_{R}} .
$$

We now expand the salinity forcing function above to account for all the rivers in our model. Then the salinity forcing functions are inserted into the MSEAS primitiveequation ocean model. Specifically, they are applied as a second term on the right 
hand side of Equation 2.5:

$$
\frac{D S}{D t}=F^{S}+\sum_{i=1}^{N_{R i v e r}} \alpha_{i}(x, y, z) \frac{\left(S_{R, i}-S\right)}{\tau_{R, i}}
$$

where $N_{\text {River }}=11$ in the current iteration of our model, and $\alpha_{i}(x, y, z)=1$ defines the coastal volume over which the bulk mixing model for river $i$ is applied $\left(\alpha_{i}(x, y, z)=0\right.$ outside this volume). The time constants $\tau_{R, i}$ are provided as inputs to the MSEAS primitive-equation model. However, as mentioned above, the total river discharge is distributed based on the horizontal footprint of $\alpha_{i}(x, y, z)$, and the vertical dependence will be discussed in Section 3.2.2.

\subsubsection{A Note on Indexing}

In Mirabito et al., the index for tau is $(j, k)$. This corresponds to river $k$ in basin $j$ and each unique $(j, k)$ corresponds to a unique index $i$ such that each river is assigned a unique index $i$. In Section 3.1.1, the generic subscript $R$ is used to indicate that the terms are specific to any selected river and should be adjusted for each river $i$. In addition, Mirabito's notation uses $Q$ for discharge flow rate with units of $\mathrm{m}^{3} / \mathrm{s}$. This thesis uses the symbol $\dot{Q}$ to indicate the same quantity using $Q$ to denote discharge (or precipitation) amounts, as seen in Section 2.5.

\subsection{Potential Improvements to the River Discharge Model and Bulk Mixing Model}

The original river discharge model (Section 2.5) and bulk mixing model of river and ocean waters (Section 3.1.1) indicated improved forecasting of ocean parameters over the ocean model without the salinity relaxation, based on comparisons with data collected during the QPE experiment. Potential areas for future improvement were also identified: time series estimation, depth of salinity relaxation, and number and shape of selected grid (finite-volume) cells were specifically sources of potential error 
and future improvement (Mirabito et al., 2012). The following section reports research completed to address some of these areas.

\subsubsection{Time Series Estimation for River Discharge}

The river discharge model uses actual river discharge data for two of Taiwan's major rivers, the Zhuóshuǐi and the Gāopíng. The data was collected at hydrological stations near the mouth of each river that remained active during the period of 06 -10 August 2009, when Typhoon Morakot passed over the island (Mirabito et al., 2012). The discharge rates of the two rivers are averaged together, then normalized and distributed among the major rivers in each basin using relative annual mean discharge values. See Section 2.5.2 for a more thorough description. Therefore, the river discharge model assumes that all rivers will reach their peak discharge at the same time. The only exceptions are the Zhuóshuǐi and the Gāopíng Rivers; the time series for these rivers use their actual discharge data in order to improve accuracy.

One possible method of improving the accuracy of this river discharge model is to use a different time series for each basin or even each river, based on the geographical position of the river and the path of the typhoon. In other words, the discharge time series would peak earlier for rivers on the east side of the island, which would have been the first to encounter the torrential rains of Morakot (see Figures 2-10(a) and $3-2)$.

Using a best track position graphic from Joint Typhoon Warning Center, shown in Figure 3-2, we know that the eye of the storm made landfall just before $1800 \mathrm{Z}$ on 07 August 2009, and the eye moved offshore just before 0600Z on 08 August 2009 (Cooper and Falvey, 2009, p. 23). The storm center took approximately twelve hours to pass over the width of Taiwan. It can be assumed that the time difference between the peak rainfall rates on the eastern and western sides of the island is approximately twelve hours, and therefore the time difference between the maximum river discharge rate on the two sides could be on the order of twelve hours.

The raw discharge rate data for the Zhuóshuǐi and the Gāopíng Rivers is shown in Figure 3-3. From this data, it is shown that the time difference between peak 


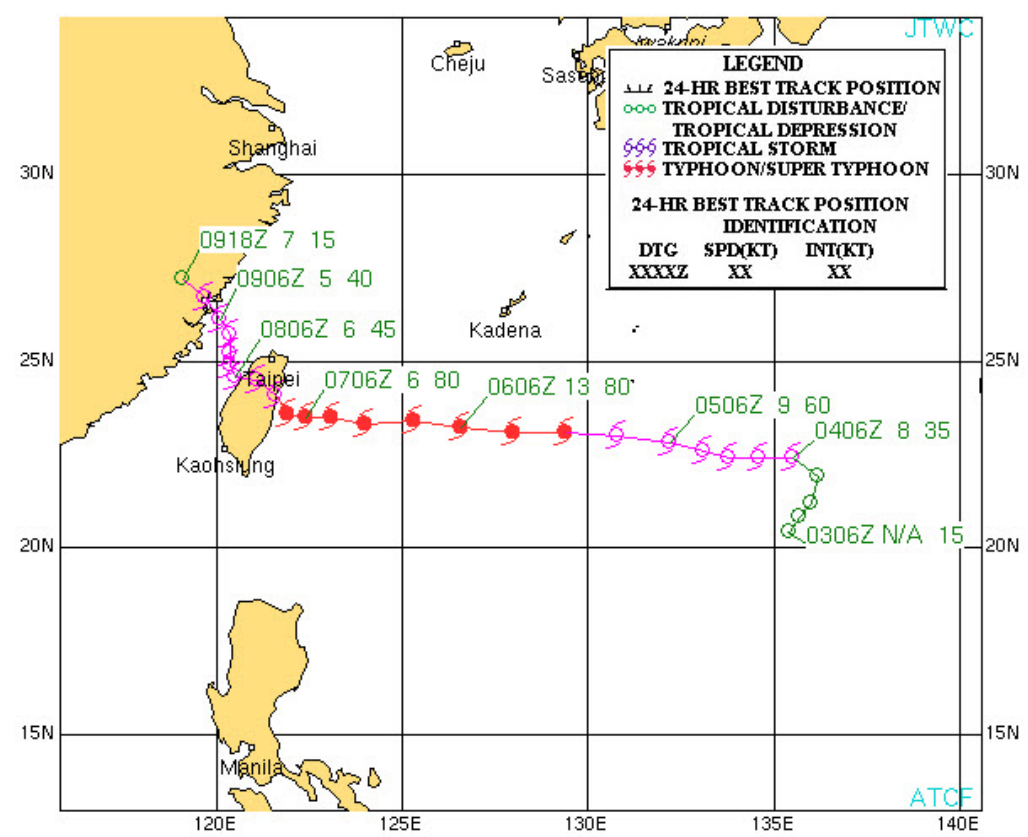

Figure 3-2: Historical Best Track for Typhoon Morakot. (Cooper and Falvey, 2009, p. 23)

discharge rates of the two rivers is on the order of hours. The Zhuóshuǐi River is located on the west-central coast of Taiwan, and in drainage basin $j=2$; the Gāopíng River is located on the southwest coast and in drainage basin $j=1$. See Figure 2-10(a). The distance between the two rivers is approximately $154 \mathrm{~km}$, or 96 miles (National Hurricane Center, 2014). Importantly, the duration of the large discharge is of the order of four days for both rivers. This duration is much larger than the few hours offset of the two peak river discharges.

For our purposes, the time difference between peak discharges is also relatively small when compared to the timeframe of our ocean primitive-equation model, which forecasts for days and even weeks. Within the context of these mid-range forecasts, twelve hours' difference is likely not sufficient to have an appreciable improvement in model accuracy. If the desired forecast period was very short-range, then the increase in model complexity may be compensated by the slight increase in accuracy. For this work, it was determined that forecast improvements from varying time series would be negligible.

Improvements to the time series accuracy could be made by incorporating addi- 


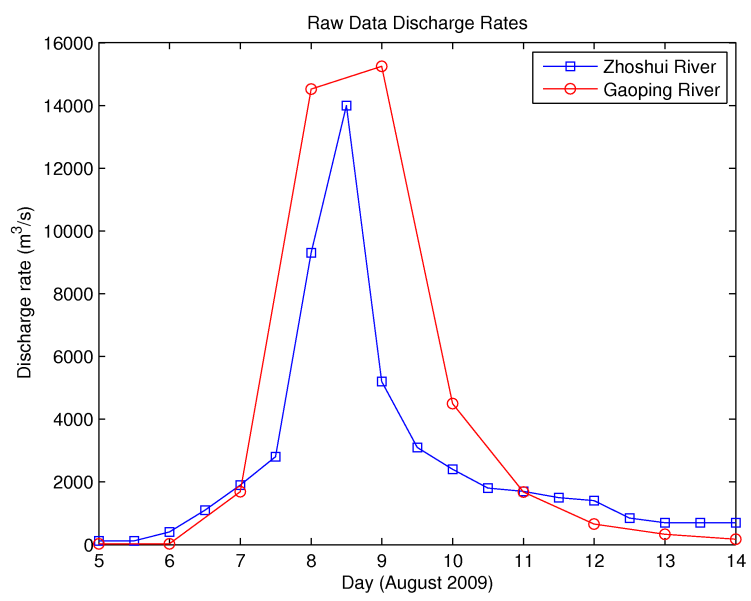

Figure 3-3: Discharge Data for the Zhuóshuǔi and Gāopíng Rivers from 5 - 14 August. (Mirabito et al., 2012)

tional discharge data into the river discharge model. This is discussed in Chapter 5.

\subsubsection{Depth of Selected Finite-Volume Grid Cells in the Bulk Mixing Model}

In the original bulk mixing model of river and ocean water, the salinity was relaxed to a uniform depth of $5 \mathrm{~m}$ (Mirabito et al., 2012). This depth was chosen to represent the depth of the river discharge. Since the relaxation salinity models a well-mixed average salinity within a selected grid cell, there is no constraint on applying the salinity relaxation only near the surface of the selected grid cells. Applying the salinity to a lower depth would model vertical mixing. During the passage of a large typhoon such as Morakot, it can be expected that vertical mixing in the upper layers of the ocean would occur. Subsequent improvements to the original model used a depth of $10 \mathrm{~m}$, which was the starting point for this study.

In order to determine if $10 \mathrm{~m}$ is the appropriate depth for the salinity relaxation, we studied the data collected soon after the passage of the typhoon by the QPE experiment.

The OR2 data, shown in Figure 3-4, was taken off the northeast coast and near the mouth of the Lányáng River (index $i=8$ ). We look at coastal station 39, as well 


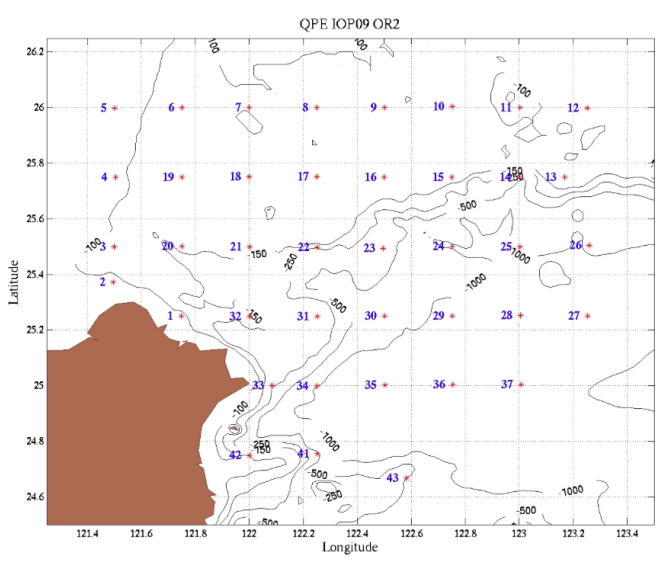

(a)

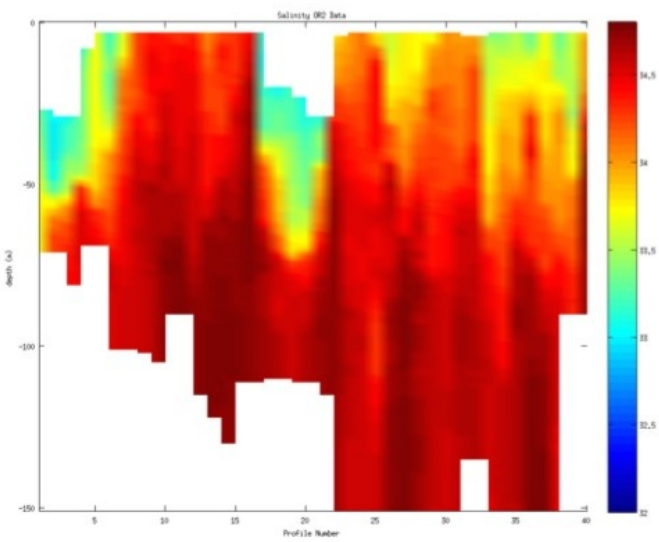

(b)

Figure 3-4: (a) Map of CTD drop locations northeast of Taiwan, taken by the $R / V$ Ocean Researcher 2 (OR2) during the period 13 - 17 August, 2009. (b) Salinity profiles from these CTD casts. (Leslie, 2012)

as stations 33, 34 and 38. To see indications of freshwater transport away from the coast, we use stations 1, 31, 32, 35 and 40. At station 39, we see low salinity, less than $33.8 \mathrm{psu}$, to a depth of approximately $50 \mathrm{~m}$. The low salinity, less than 33.6 psu, is present to a depth of approximately $20 \mathrm{~m}$. Stations 32 - 36 also have very low salinities, less than $33.6 \mathrm{psu}$, to a depth of approximately $10-15 \mathrm{~m}$.

In the OR3 data, shown in Figure 3-5(b), we have data just offshore for rivers with indices $3-6$. Stations 1 - 3, 7 - 10, 23 - 25, and $34-37$ are all close to shore and could reflect lower salinities from freshwater discharge. In addition, stations 12 , 26, 33 and 38 may indicate the transport of this freshwater from near-shore waters. Upon examination of the data, we see stations 1 - 3 have very low (less than 33.6 psu) salinities to a depth of approximately $15 \mathrm{~m}$. Stations 7 - 10 show lowest values to the ocean bottom, which is approximately $15 \mathrm{~m}$. Stations 23 - 25 show salinities below 33.6 psu to a depth of about $25 \mathrm{~m}$, and stations 34 - 37 indicate lowest salinities only to about $15 \mathrm{~m}$.

In general, the salinities are much lower on the western side of the island than on the northeast side, typically below 33.9 psu while the northeast casts show salinities above 34.4 psu. Per Newhall et al. (2010), the water mass northeast of Taiwan has typical salinity ranges of 33 - 34.8 psu. After the passage of Typhoon Morakot, 


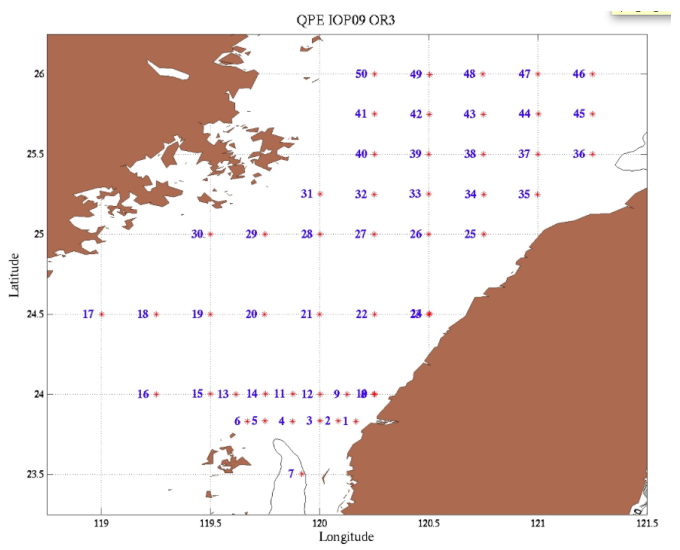

(a)

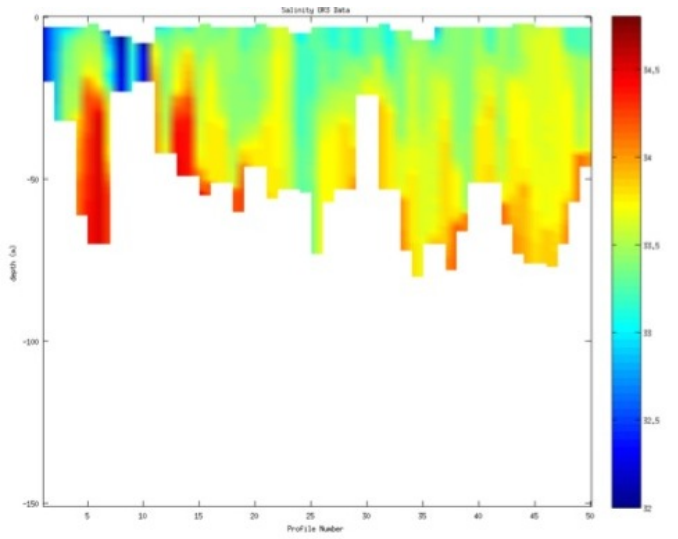

(b)

Figure 3-5: (a) Map of CTD drop locations northeast of Taiwan, taken by the $R / V$ Ocean Researcher 3 (OR3) during the period 13 - 17 August, 2009. (b) Salinity profiles from these CTD casts. (Leslie, 2012)

"typhoon-induced brackish warm water was found off the northen tip of Taiwan. The salinity was as low as 32 around the northwestern tip of Taiwan. Since the runoff was modest for the rivers in the northern Taiwan, this freshwater source must have originated from the southwest coast of Taiwan." The oceans west of Taiwan are over the shelf, shallower and fresher than the slope waters to the northeast, where salty Kuroshio water mixes with the shelf waters flowing down the slope. Specific profiles were identified by Newhall et al. (2010) as being impacted by freshwater river discharge. These salinity profiles and their locations are shown in Figure 3-6.

From the above analysis, several new test depths were selected. Depths of 20, 35 and $50 \mathrm{~m}$ were selected to test the extremes and to allow a bracketing of the best mixing depth. Recall from Equation 3.9 that the relaxation time-scale $\tau(t)$, where $t$ is time, in the salinity forcing Equation 3.10 depends on the volume of the selected finite-volume cells, which is determined by the number of cells and the depth to which the salinity relaxation factor is applied, i.e.

$$
\tau=\frac{N V}{\dot{Q}}
$$

The time series of $\tau$ depends on the volume over which the salinity relaxation is applied, and was therefore re-computed for each of the new test depths 20, 35 and 50 


\section{$T(z)$ and $S(z)$ are plotted for the stations outlined in blue. $\mathrm{S}<33$ is found in green regions. $\mathrm{S}<32.5$ is found in red area.}
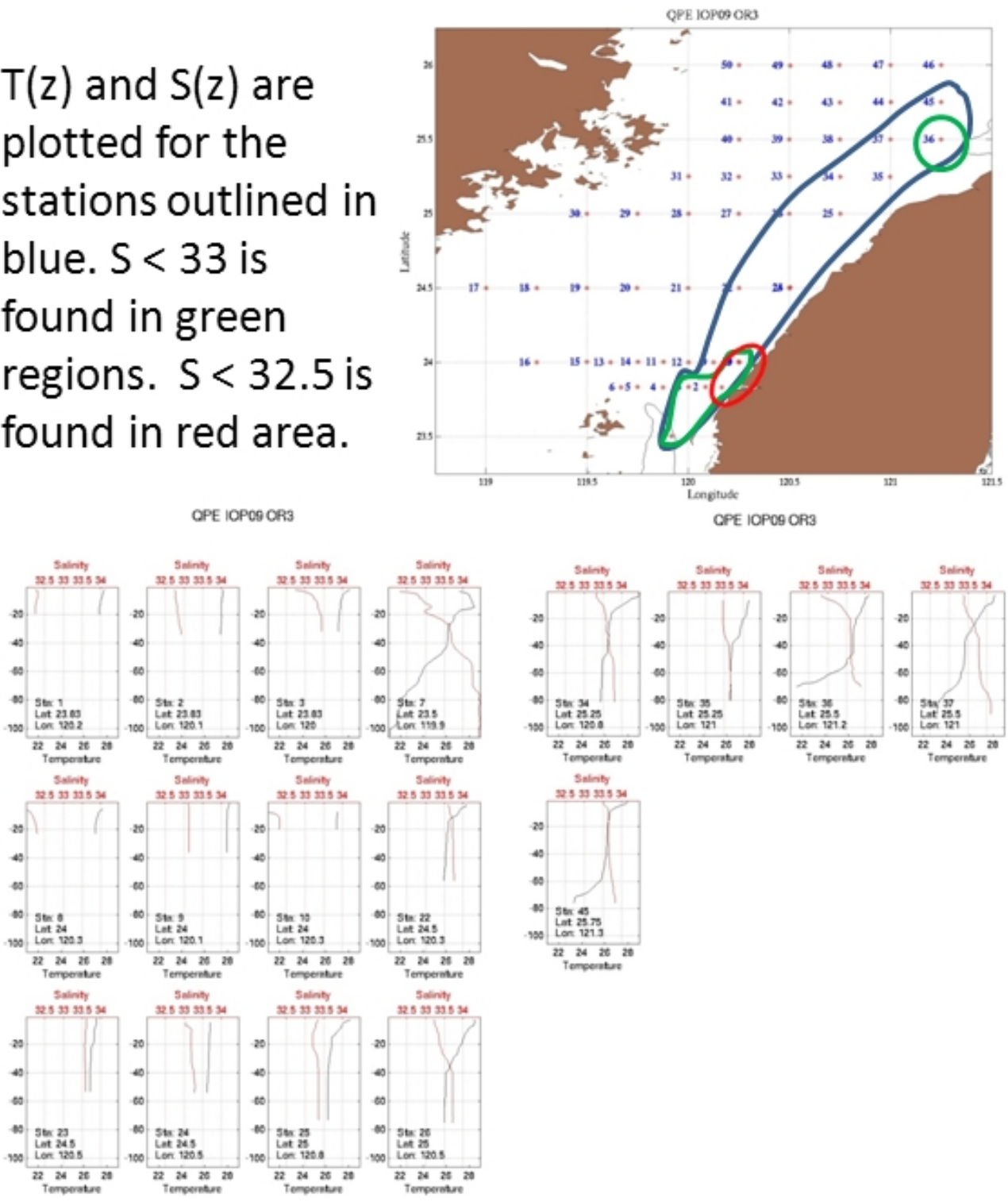

Figure 3-6: Salinity profiles and locations of low salinity observations in the wake of Typhoon Morakot. (Leslie, 2012) 
$m$ and applied to the existing river model. After these initial tests and our analysis of their results, as well as updates to the area over which we apply the bulk mixing, i.e. the finite-volume grid cell configuration, and changes to the grid cell configuration discussed in Section 3.2.4, new model runs to depth of 10, 15, 20 and $35 \mathrm{~m}$ were completed. See Chapter 4 for a more detailed explanation.

\subsubsection{Salinity Relaxation Values}

The original river discharge model tested multiple values of river salinity $S_{R} ; 10,15$ and 20 psu were tested. The best choice was selected by comparison with observations, and $S_{R}=10$ psu was deemed the most accurate (Mirabito et al., 2012). Subsequently, data was obtained to indicate that $S_{R}=18 \mathrm{psu}$ gave more accurate results when compared with QPE data, and with other minor changes to the model. For this study, $S_{R}=18 \mathrm{psu}$ was used.

If the model output salinity approaches the river, or relaxation, salinity $\left(S\right.$ and $S_{R}$, respectively, in Equation 3.10), then the river discharge model is no longer approximating an input of relatively fresh water as compared to the surrounding seawater. The model output is confirmed to maintain minimum salinities well above the relaxation salinity of 18 psu.

\subsubsection{Number and Shape of Selected Grid Cells}

The number and configuration of grid cells for salinity relaxation was another possible area for significant improvement of the bulk mixing model. The original model was tested with $n=4$ and $n=7$ grid cells per river (Mirabito et al., 2012). However, simulations with this bulk model indicate a too small foot print for the rivers and too low salinities when compared to observed values near the river mouths. Hence, hindcast simulations using a larger footprint were determined to more closely match the available data.

Hence, six new configurations, or shapes, were created and tested. All used the original $n=7$ grid cells per river and therefore used the original time series. The shape 
of the configurations was based off surface salinity model forecasts from the original river discharge model; the grid cells selected for salinity relaxation were chosen to mirror the shape of the low salinity areas near the mouths of the rivers. A sampling of new configurations is shown in Figure 3-7.

After evaluating these results, it was found that even $n=7$ may not be a large enough footprint to accurately capture the bulk mixing occuring from the freshwater discharge input. Three more configurations, consisting of $\mathrm{n}=10, \mathrm{n}=14$, and $\mathrm{n}=25$ finite-volume grid cells per river mouth were created and tested. The large number of cells and the close proximity of the river mouths, especially for rivers $i=4-6$ (the Wū, Dàjiă and Dàān Rivers, respectively) resulted in one large combined footprint on the western side of the island. These configurations are shown in Figure 3-7.

\subsection{Sensitivity Studies of the MSEAS Ocean Model}

Section 3.2 discusses many updates that could potentially improve the accuracy of the river discharge model and bulk mixing model. Since the river discharge model is used as an input into the MSEAS primitive-equation ocean model, it would be remiss to ignore sensitivity studies of this larger model. One such study done during the scope of this project was a "restart" study. This method was used to examine the effects of tidal forcings and atmospheric forcings on oceanographic properties.

The concept is to run the model for a pre-determined time, then remove a forcing and let the model continue to run. A "control" run is also done, keeping the forcings in place throughout the run. Then, a comparison can be made between the restart and the control to determine the effects of the forcing.

This study included an analysis of the impacts of the atmospheric forcings and the tidal forcings. Two sets of restarts were run, with each one removing one of the forcings. The forcings were removed after 7, 14, 21 and 28 days; the total timeframe for this study was 37 days. Each restart run was completed with and without data assimilation; the assimilation scheme was adapted to compensate for the new timeframes. 


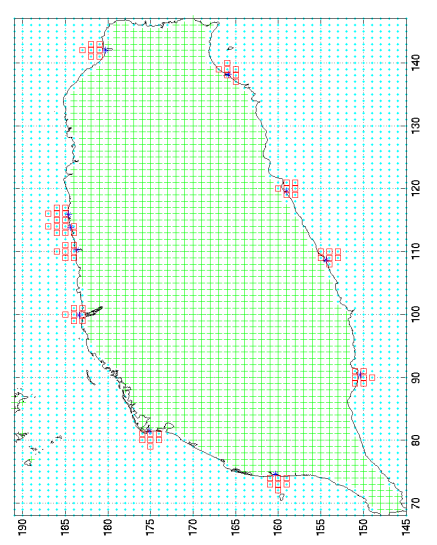

(a)

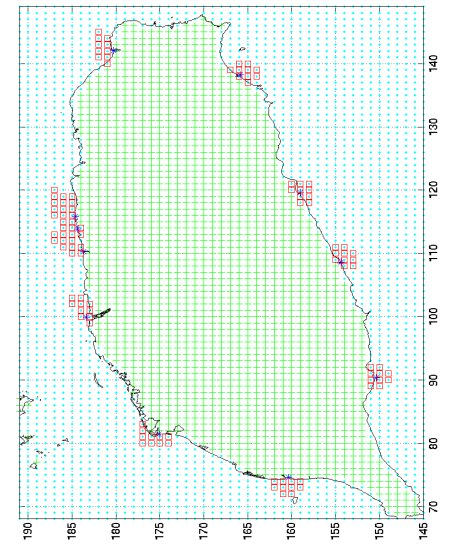

(d)

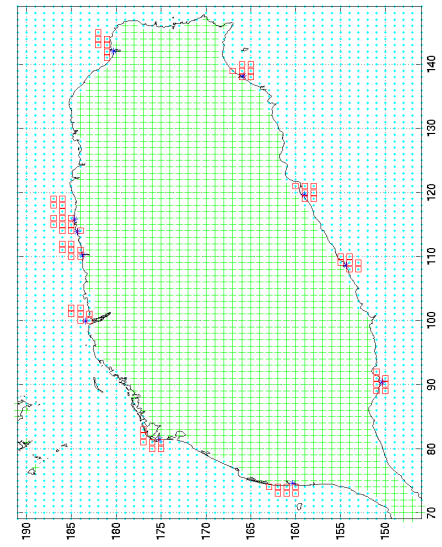

(b)

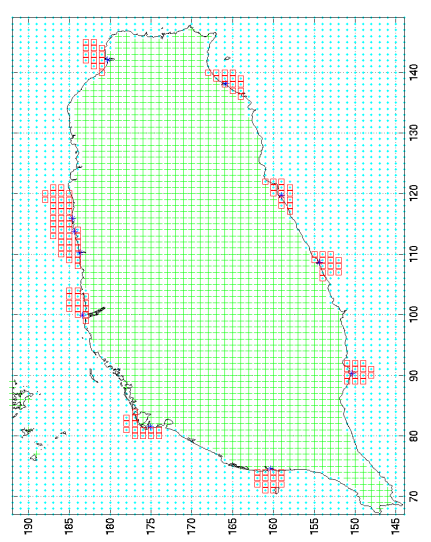

(e)

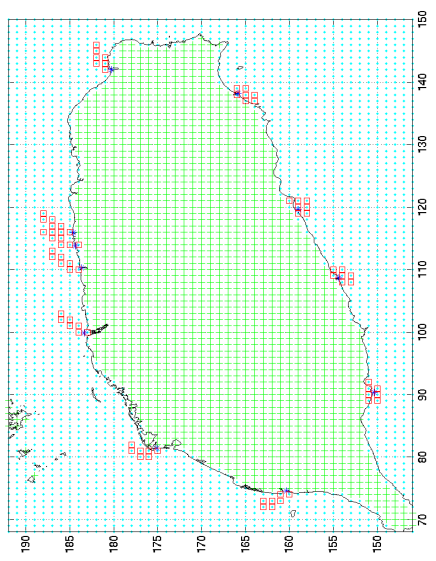

(c)

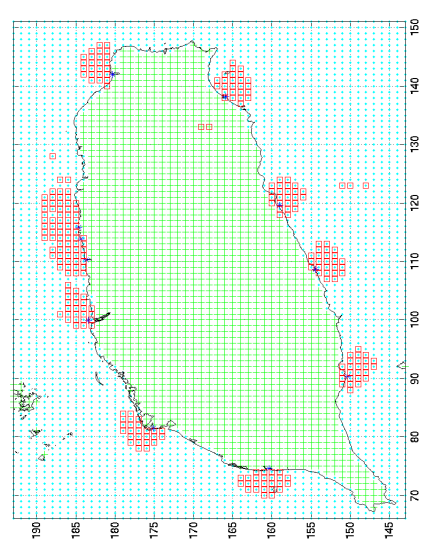

(f)

Figure 3-7: Comparison of grid cell configurations. Salinity relaxation grid cells are marked with red boxes.(a) Original configuration. (b) A new configuration, called Test 5, maintaining original $n=7$ grid cells per river. (c) Another new configuration, called Test 6 , with $\mathrm{n}=7$ grid cells per river. (d) A configuration, called Test 7, increasing to $\mathrm{n}=10$ grid cells per river. (e) A configuration, called Test 8 , increasing to $\mathrm{n}=14$ grid cells per river. (f) A configuration, called Test 9 , increasing to $\mathrm{n}=25$ grid cells per river. 
THIS PAGE INTENTIONALLY LEFT BLANK 


\section{Chapter 4}

\section{Results}

We study the results of the different runs to determine the best combination of parameters for accurate salinity forecasting. All Figures in this section show model runs with no data assimilation, unless otherwise noted.

\subsection{Effects of Footprint Shape on the Bulk Mixing Model}

We begin by examining the results of MSEAS primitive-equation ocean model runs with no river forcing and with the original river forcing from Mirabito et al. (2012). We then compare these to new runs done with different overall shapes in the grid cell footprint. All of these first runs did not utilize any changes in the total volume over which the salinity relaxation was applied; that is, the volume was $n=7$ and 10 $m$ depth for these initial tests.

We note that a large number of simulations were completed. Here, we only report on a subset of these simulations, selected to illustrate the results.

Comparing the surface salinity forecasts from the the MSEAS model run without river forcing (Figure 4-3) to the salinity forecasts utilizing the original river discharge model (Figure 4-4) shows the marked difference made by the use of the river discharge model. The lower salinities in the coastal waters off Taiwan, especially on the western 


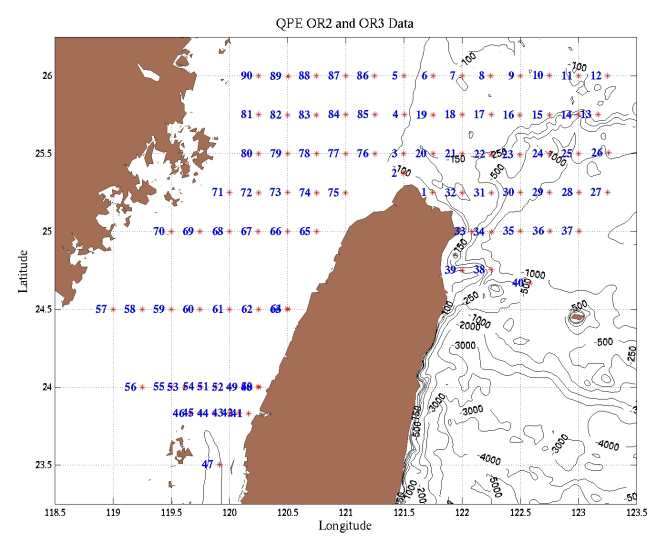

Figure 4-1: Map of CTD drop locations taken by the $R / V$ Ocean Researcher 2 (OR2) during the period 13 - 17 August, 2009. This is a combination of the data profiles shown in Figures 3-5(a) and 3-4(a). (Leslie, 2012)

side of the island, more closely match the data obtained during the QPE DRI. Figures 4-5 and 4-6 show the surface salinity forecast for our Tests 5 and 6, respectively. Each keeps the original $n=7$ grid cells, but in a different geographical configuration than the original model (see Figure 3-7(a)-(c)). The different shapes were created with the overall ocean flow in mind; the shapes were drawn to show strong advection into surrounding currents, spread along the coast, or discharge directly away from the coast, ignoring ocean flows. Despite the different shapes, the surface salinity forecasts appear similar to the original river model.

In Figure 4-7(a), (b), and (c), we show the differences between these forecasts and the data. Any differences are very subtle. These plots include a profile for all available data, over 100 profiles, corresponding to CTD cast locations shown in Figure 4-1. Our data is for 13 - 17 August 2009, which is only a few days after the passage of Typhoon Morakot. Thus, we do not expect to see significant salinity impacts at large distances from the coast. Having too much irrelevant data can disguise our results; hence, we choose to focus only on the profiles that would be affected by freshwater river discharge. In particular, six profiles have been identified as being impacted by river discharge (Newhall et al., 2010). We now generate plots comparing the model forecast salinities to the salinity data for only these plots. Using this approach, subtle but significant differences between model runs become more obvious. 


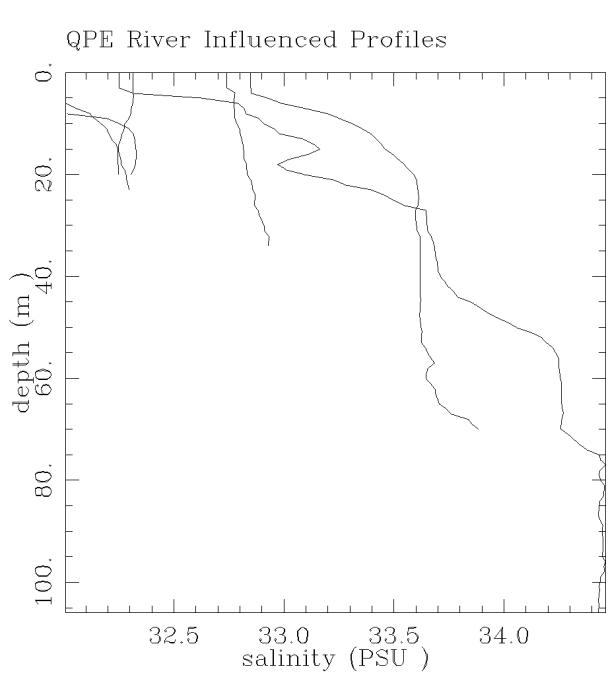

(a)

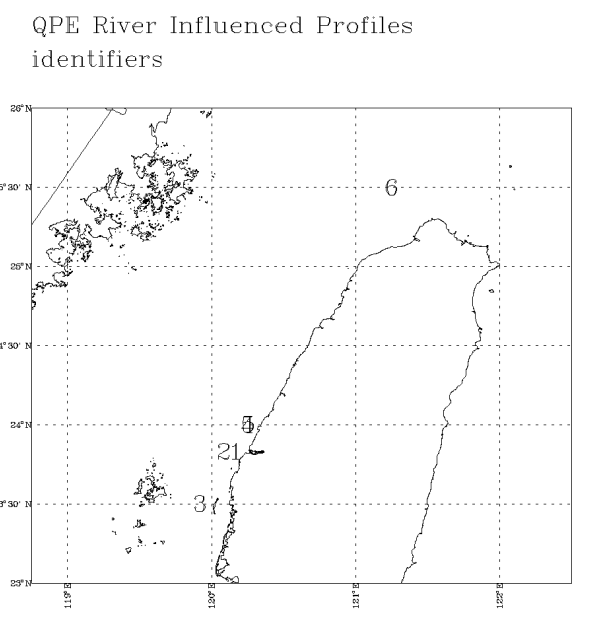

(b)

Figure 4-2: Salinity profiles taken 13 - 17 August 2009 for the six locations that have been identified as being impacted by freshwater river discharge by Newhall et al. (2010). (a) shows salinity variations with depth in these six profiles, while (b) shows the locations of these profiles.

We now study Figure 4-8, which compares the river-impacted profiles for the original model, as well as our new Tests 5 and 6 . This Figure shows that the impact on salinity in river-impacted profiles is still very similar for the three forecasts. There is very little difference evident between plots of different cell configurations when the configurations have the same number of cells; however, Test 6 is slightly better than the other two options.

\subsection{Effects of the Horizontal Extent of the Bulk Mix- ing Model}

We design two new configurations, increasing the the size of the fresh-water footprint from a number of cells $n=7$ to $n=10$ and $n=14$. We also generated a very large footprint model, Test 9 , with $\mathrm{n}=25$ grid cells. These shapes are diagrammed in Figure 3-7(d)-(f)). As before, the various shapes were carefully created to account for ocean currents, studied from runs without salinity forcing, as well as to mirror 
salinity mixing patterns seen in previous runs. We chose not to investigate a smaller footprint, as this was previously studied by Mirabito et al. (2012) and determined less accurate than the original $n=7$ configuration.

The comparisons of these tests are shown in Figure 4-7(d)-(f). Again, the full profile plots obscure the desired data, so we analyze the plots with selected riverimpacted profiles in Figure 4-9.

Here, we see a clear improvement using the $n=25$ configuration. There is a reduction in salinity differences from the data in all profiles.

\subsection{Effects of the Depth of the Bulk Mixing Model}

A separate study was done to determine the effect of the salinity relaxation depth on the model salinity forecasts. The original model, as well as the new configurations, were run with different bulk mixing model depths and the results compared in Figure 4-10. Again, the differences from the data were plotted for all the profiles, as well as for the river-impacted profiles.

As seen in the the previous results, Test 6 was slightly better than the original and Test 5 configurations (Figure 4-11). Comparing Test 6 with the forecasts for larger footprints (Figure 4-12) again shows that Test 9, with $n=25$ cells, is slightly better than the other tests, although the improvement is less marked at $20 \mathrm{~m}$ than at 10 m. The configurations were also run using a salinity relaxation depth of $35 \mathrm{~m}$, which showed less improvement than the $20 \mathrm{~m}$ and is not included here.

As the $\mathrm{n}=25$ configuration was the best choice at both 10 and $20 \mathrm{~m}$, this new configuration was run with another, new salinity relaxation depth of $15 \mathrm{~m}$. Then these three runs were compared to the data; the comparison of results is shown in Figure 4-13. The combination of the largest footprint and the original depth most closely matches the data from 13 - 17 August. 


\subsection{Final Results}

Figure 4-14 shows the surface salinity hindcast for the MSEAS primitive-equation ocean model run using the $n=25$ configuration with salinity relaxation to a depth of $10 \mathrm{~m}$. Figure 4-15 shows the same model run, using data assimilation techniques (Haley and Lermusiaux, 2010) (Haley et al., 2014).

On August 7, the current pattern shifts on both the western and eastern side of the island, following the northwestward track of Typhoon Morakot (refer to Figure 3-2). Beginning on August 9, the effects of the river discharge become obvious with the low salinities concentrated in the coastal waters around Taiwan. This is most noticeable on the western shore, where 4 large rivers flow into the sea relatively close together. These salinity lows are evident throughout the forecast period, although they are strongest on August 9, in the middle of the period of heaviest rainfall. 


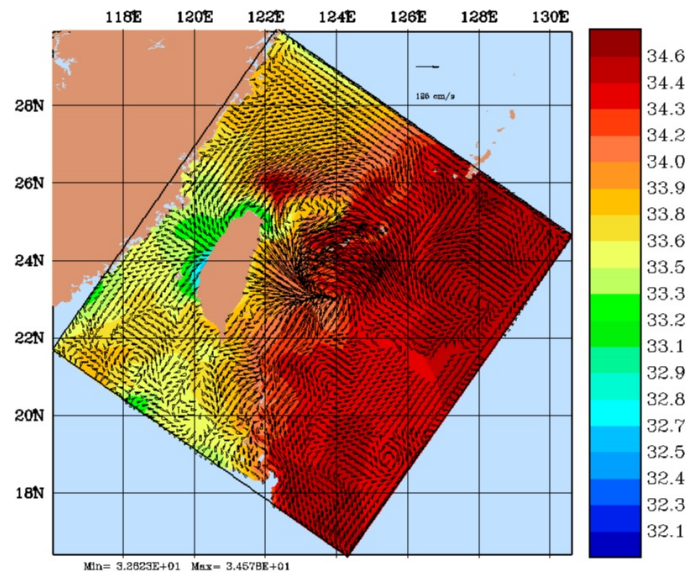

(a) August 07

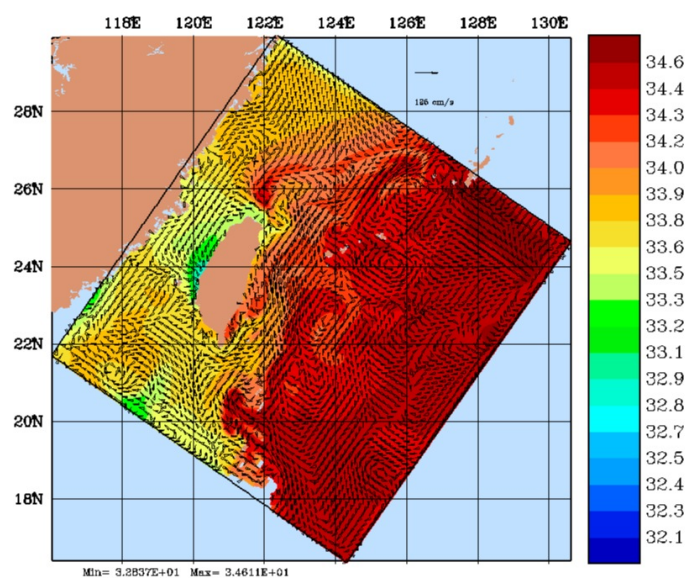

(c) August 13

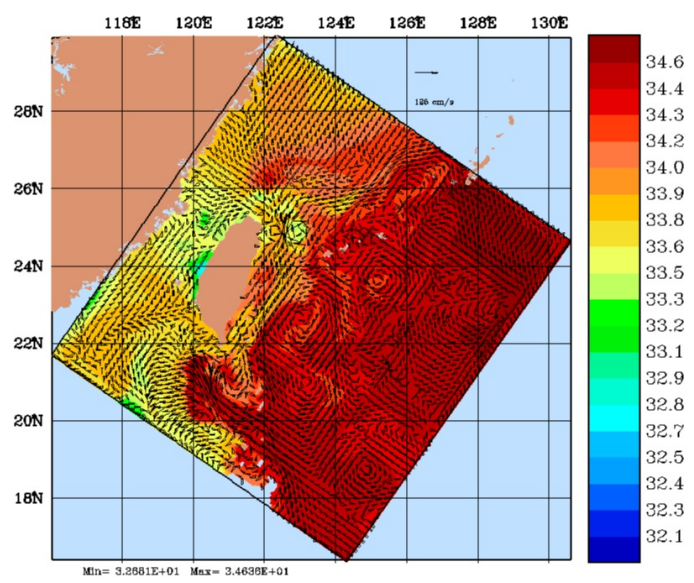

(e) August 19

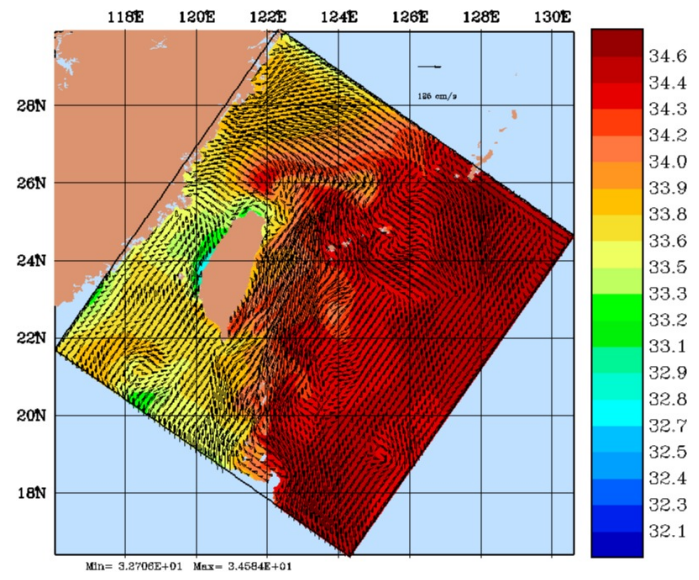

(b) August 09

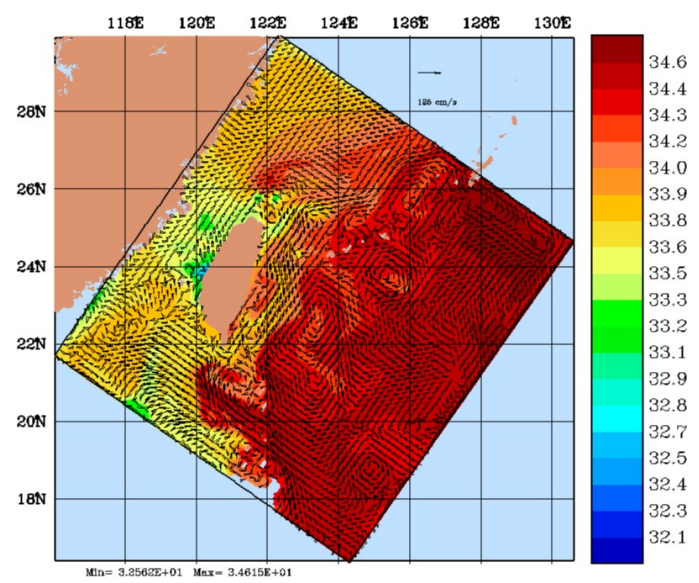

(d) August 17

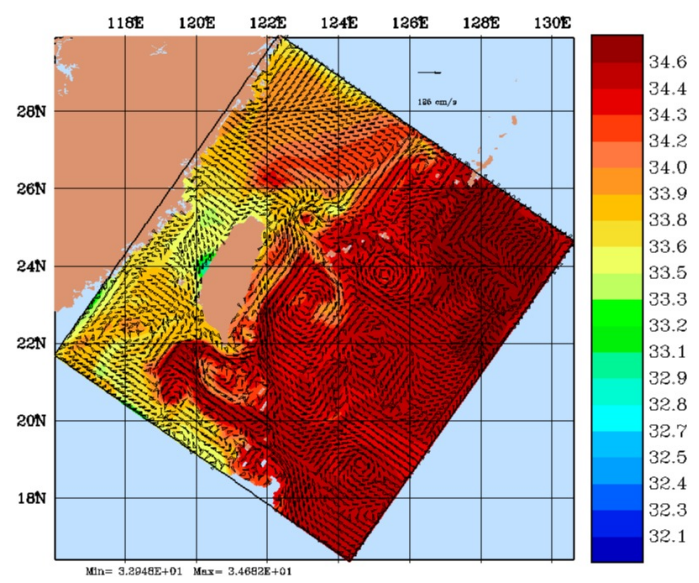

(f) August 25

Figure 4-3: Surface salinities forecast by the MSEAS ocean model with no river forcing. This run was completed for comparison purposes. 


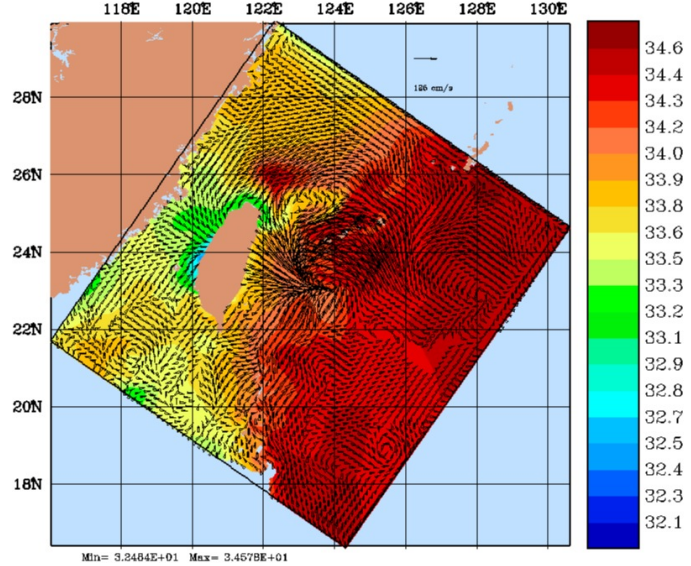

(a) August 07

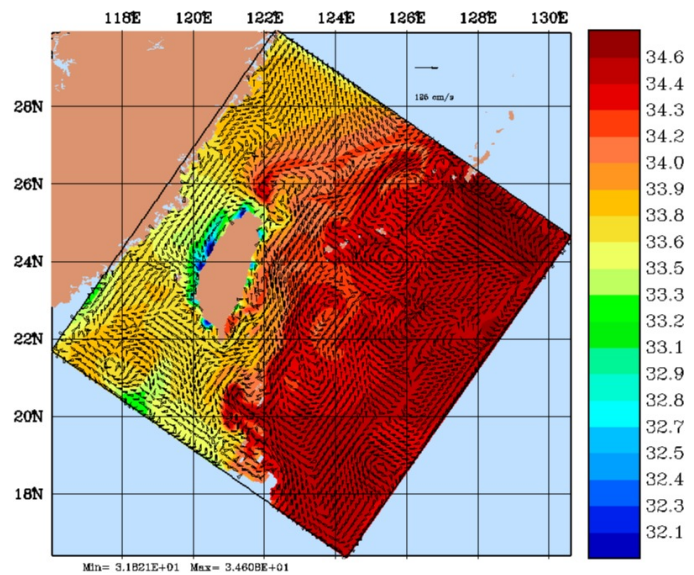

(c) August 13

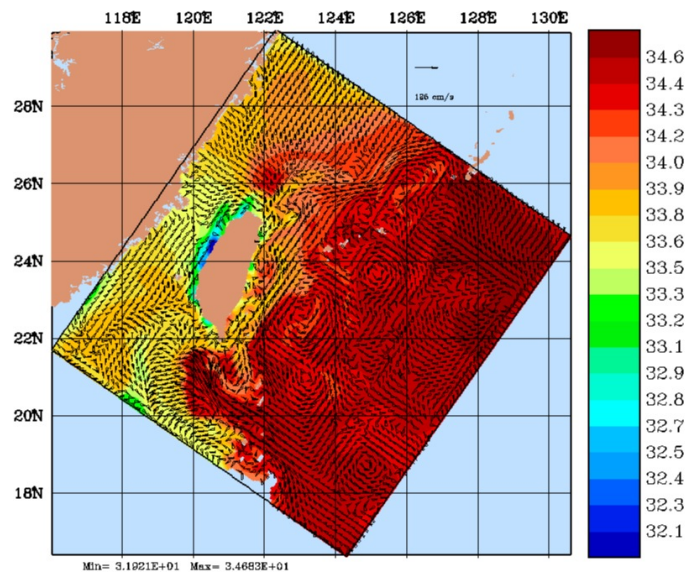

(e) August 19

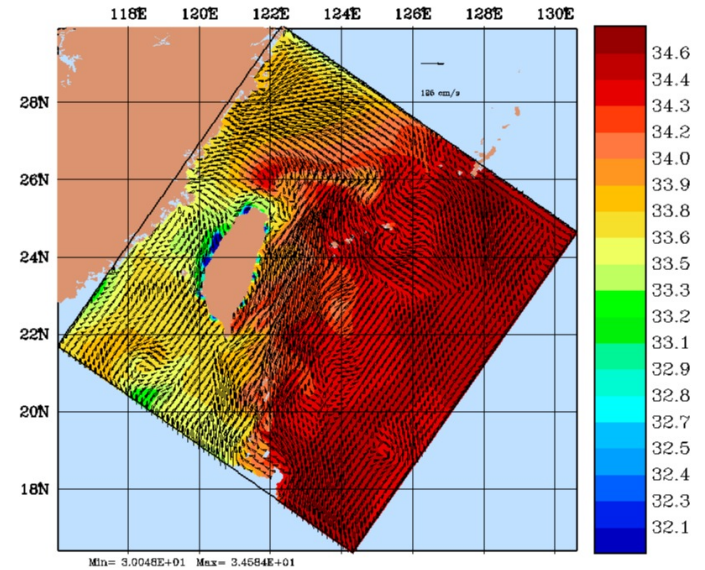

(b) August 09

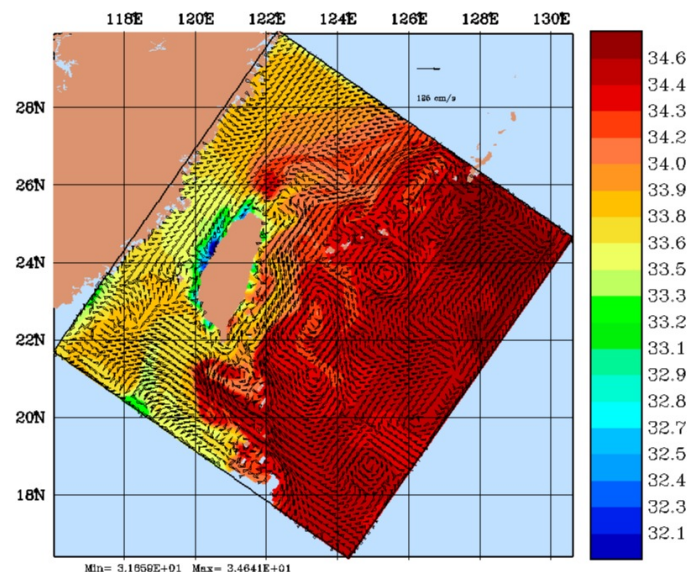

(d) August 17

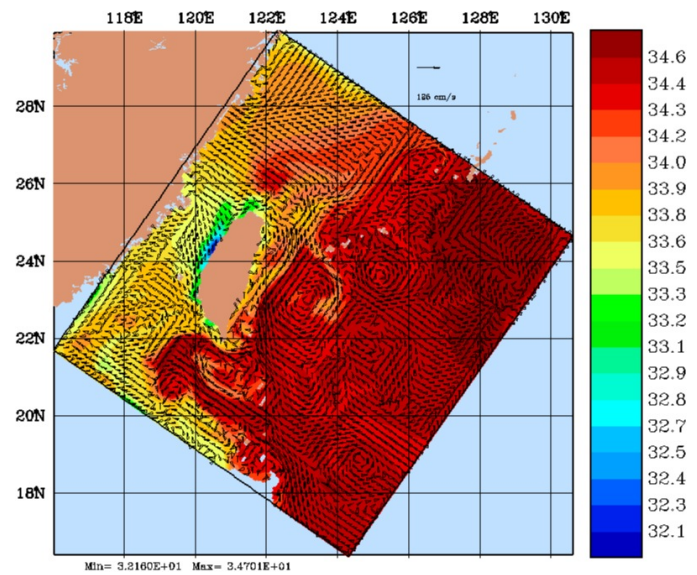

(f) August 25

Figure 4-4: Surface salinities forecast by the MSEAS ocean model with the original river forcing, using $\mathrm{n}=7$ finite-volume cells, with salinity relaxation applied to a depth of $10 \mathrm{~m}$. The configuration is shown in Figure 3-7(a). This run was completed for comparison purposes. 


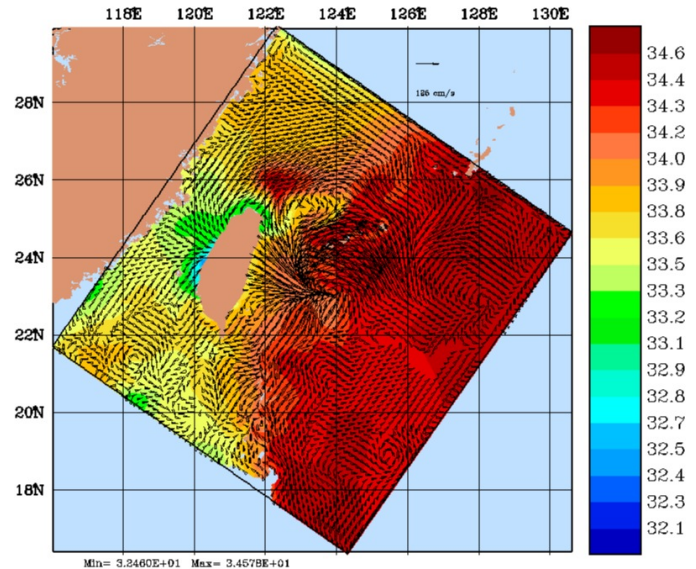

(a) August 07

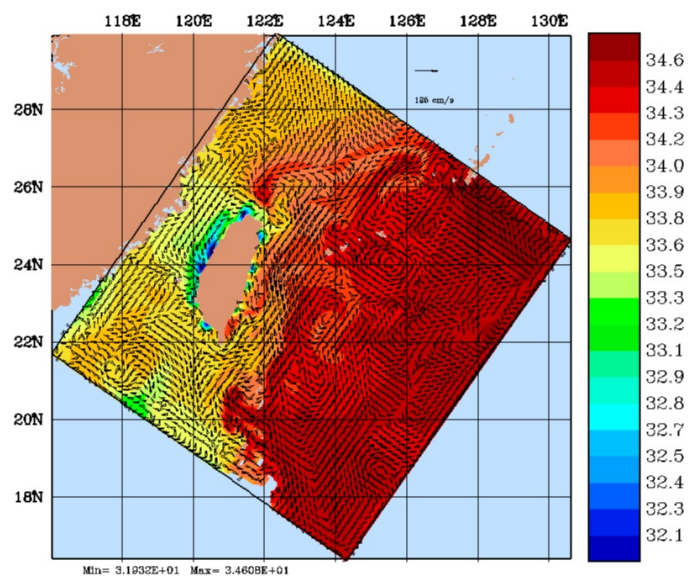

(c) August 13

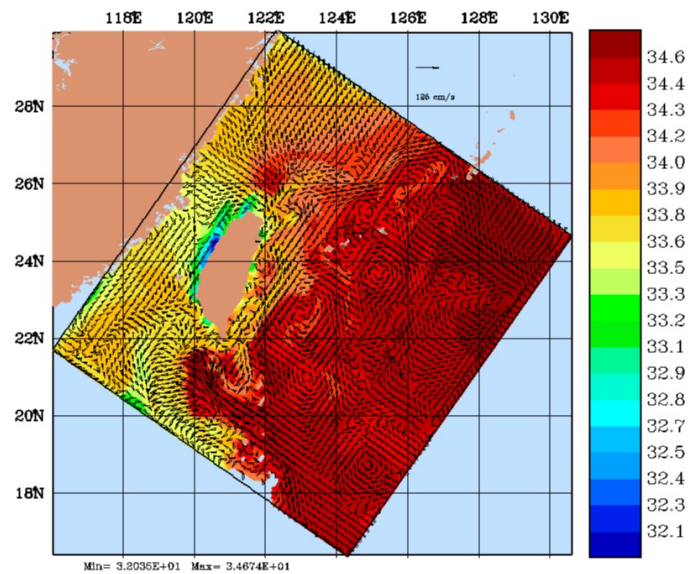

(e) August 19

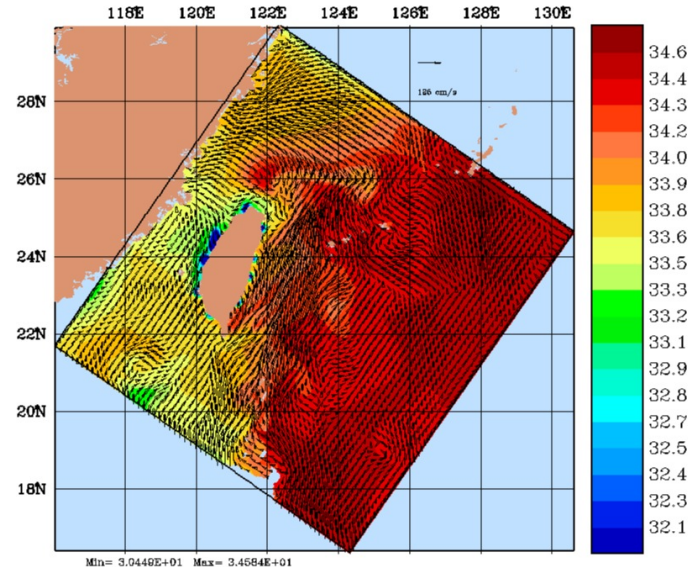

(b) August 09

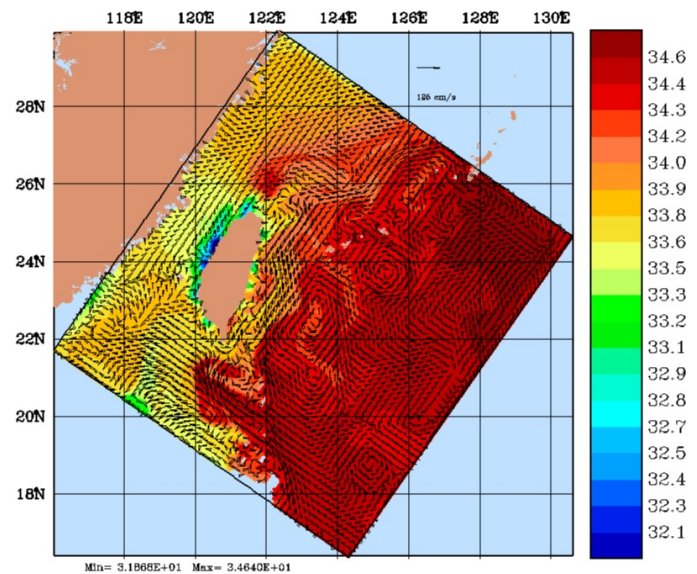

(d) August 17

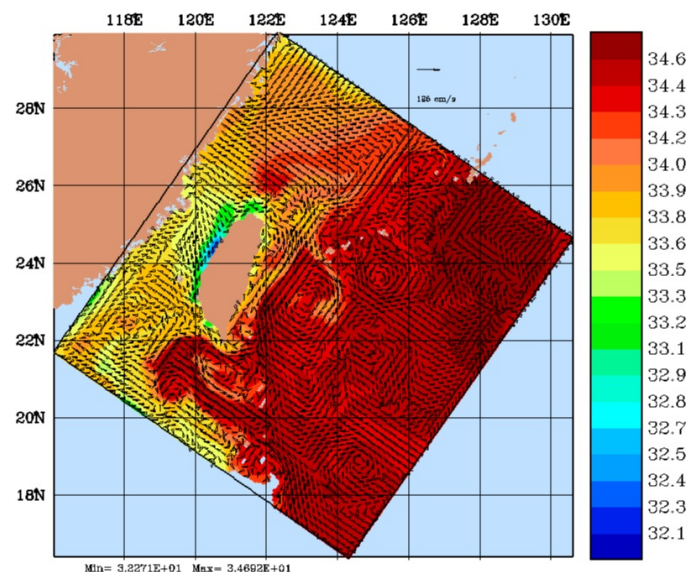

(f) August 25

Figure 4-5: Surface salinities forecast by the MSEAS ocean model with configuration Test 5 , using $\mathrm{n}=7$ finite-volume cells, with salinity relaxation applied to a depth of $10 \mathrm{~m}$. The configuration is shown in Figure 3-7(b). 


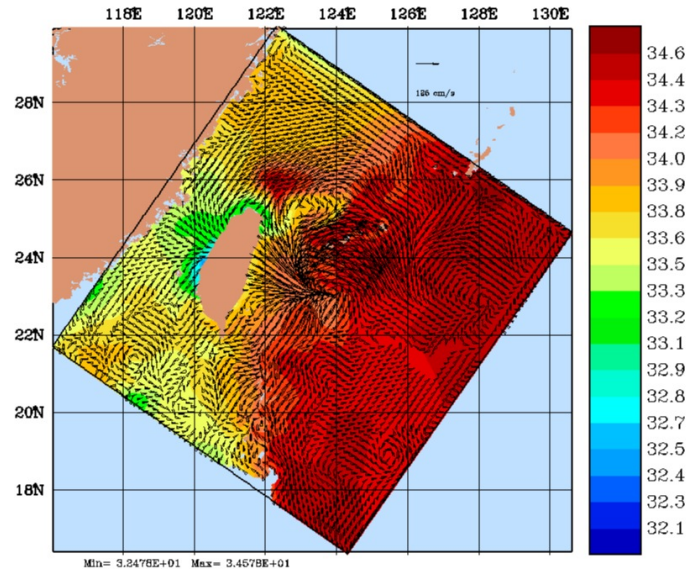

(a) August 07

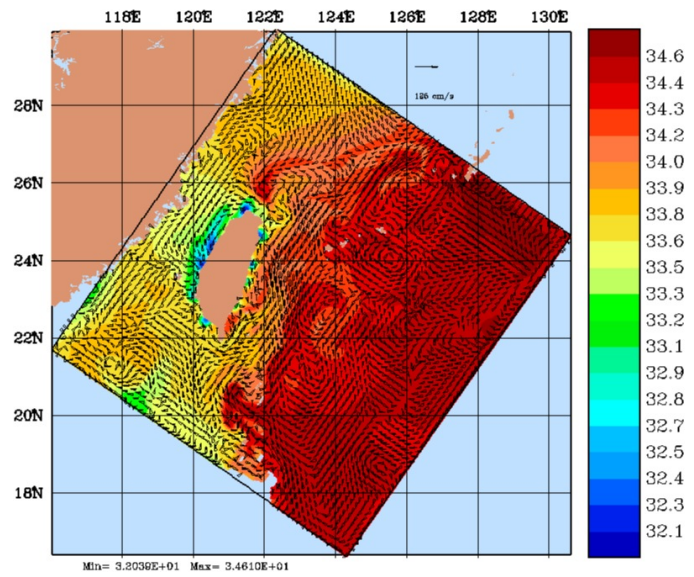

(c) August 13

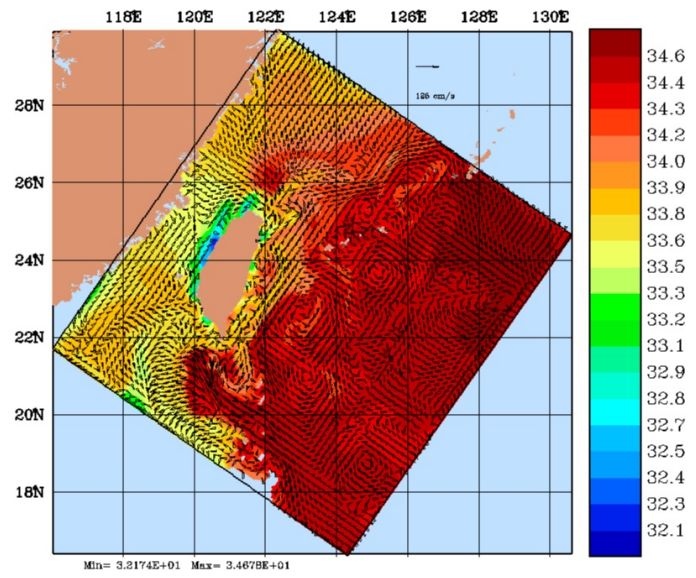

(e) August 19

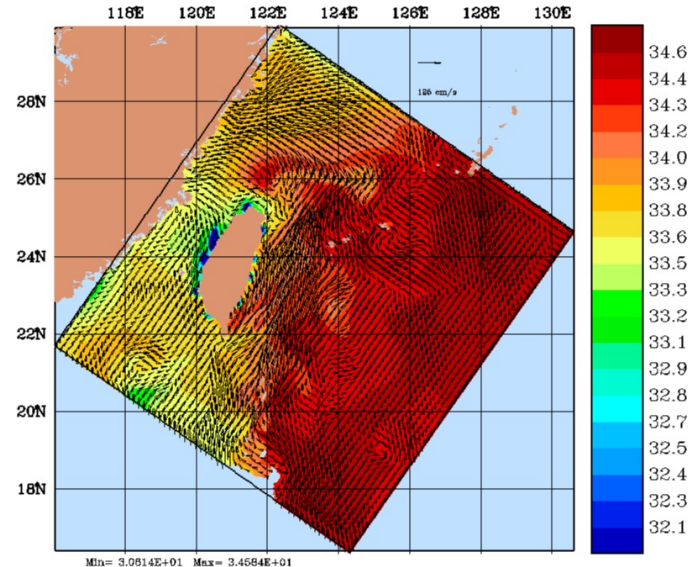

(b) August 09

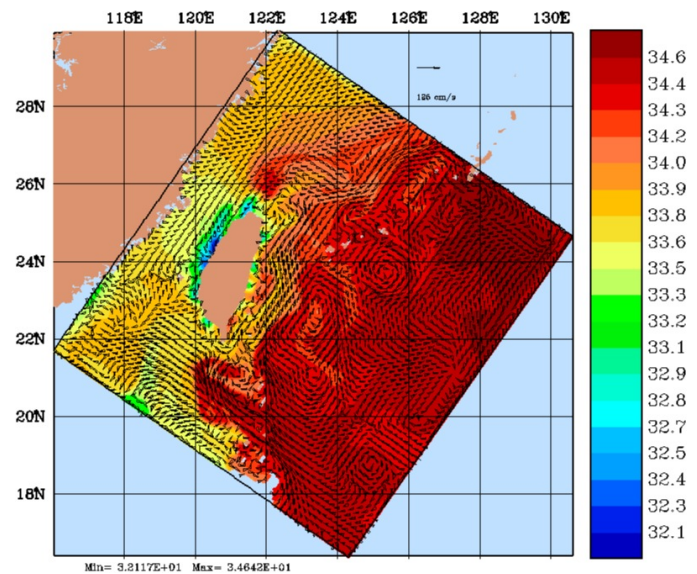

(d) August 17

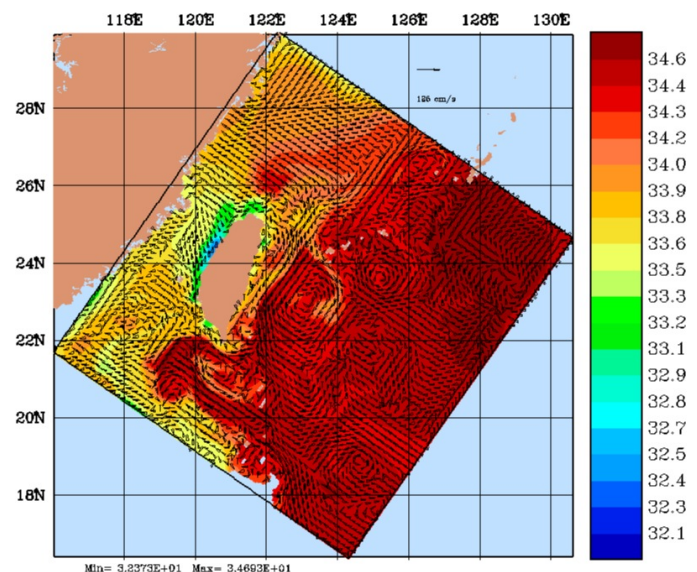

(f) August 25

Figure 4-6: Surface salinities forecast by the MSEAS ocean model with configuration Test 6 , using $\mathrm{n}=7$ finite-volume cells, with salinity relaxation applied to a depth of $10 \mathrm{~m}$. The configuration is shown in Figure 3-7(c). 


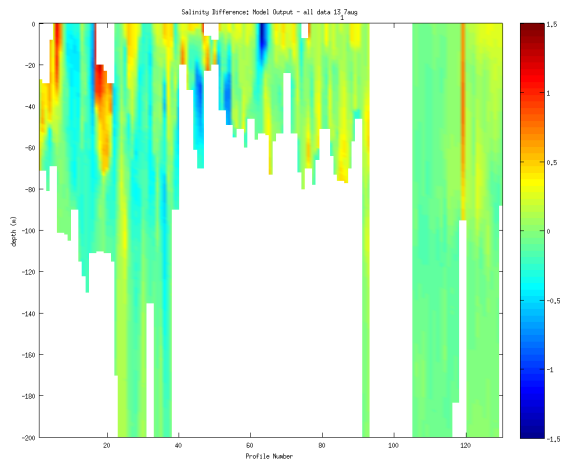

(a) Original (7 cells) @ $10 \mathrm{~m}$

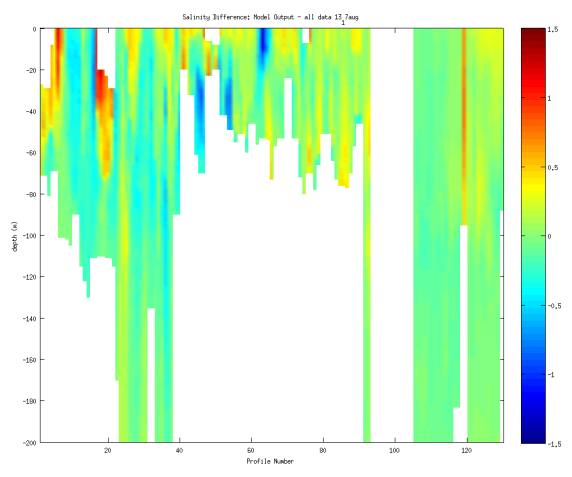

(c) Test 6 (7 cells) @ $10 \mathrm{~m}$

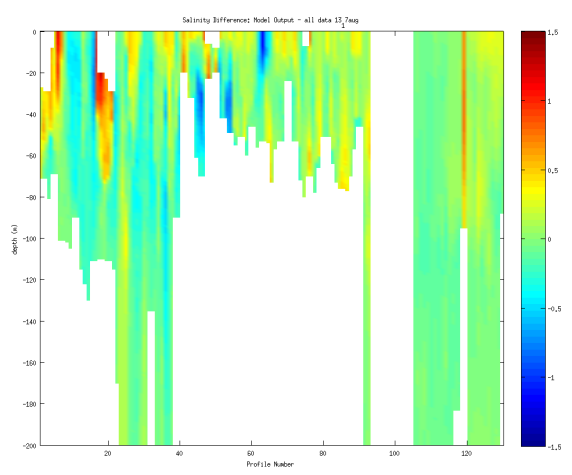

(e) Test 8 (14 cells) @ $10 \mathrm{~m}$

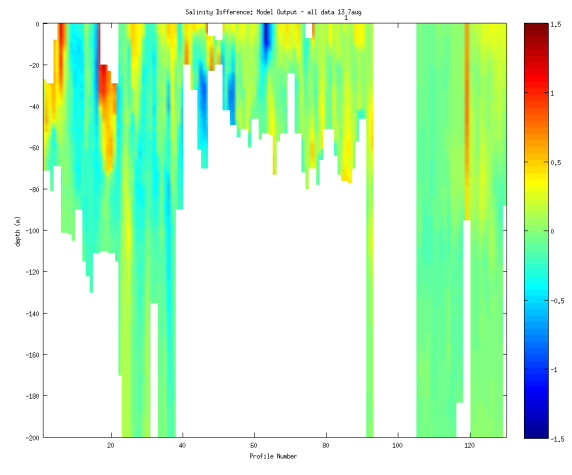

(b) Test 5 (7 cells) @ $10 \mathrm{~m}$

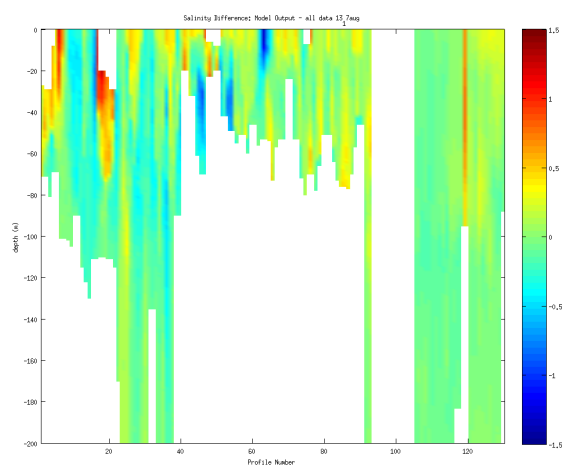

(d) Test 7 (10 cells) @ $10 \mathrm{~m}$

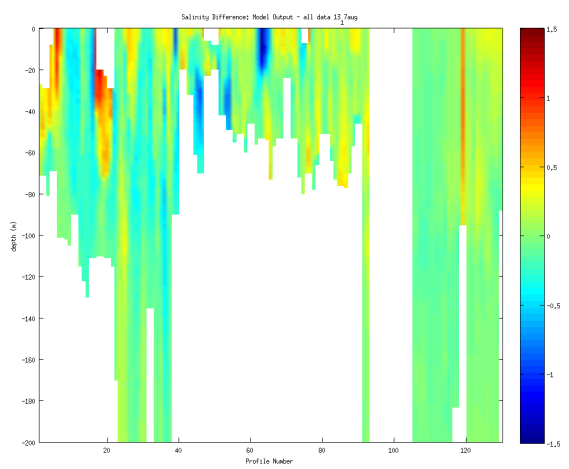

(f) Test 9 (25 cells) @ $10 \mathrm{~m}$

Figure 4-7: Comparisons of salinity data with MSEAS salinity forecasts using different configurations of the bulk mixing model, with salinity relaxation to a depth of $10 \mathrm{~m}$. Plots show the data subtracted from the specified model output. The profile locations are shown in Figure 4-1. 


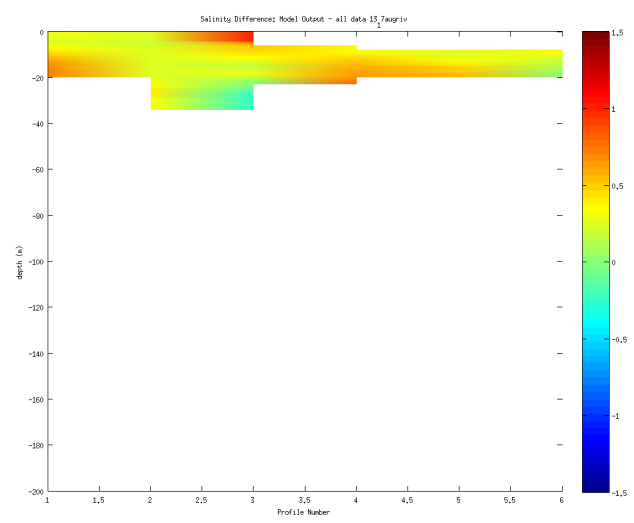

(a) Original (7 cells) @ $10 \mathrm{~m}$

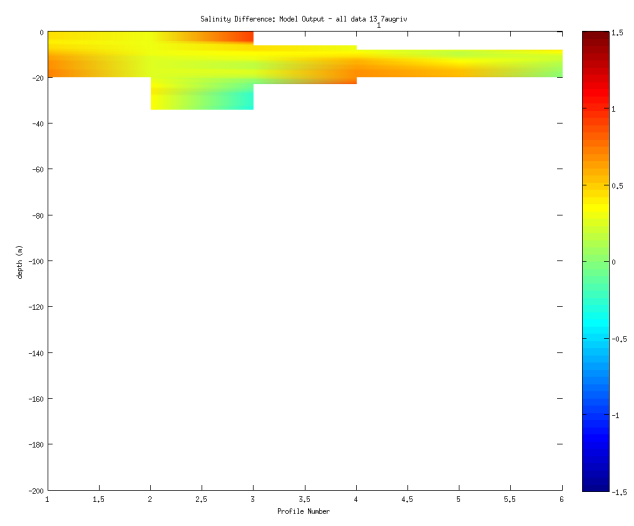

(b) Test 5 (7 cells) @ $10 \mathrm{~m}$

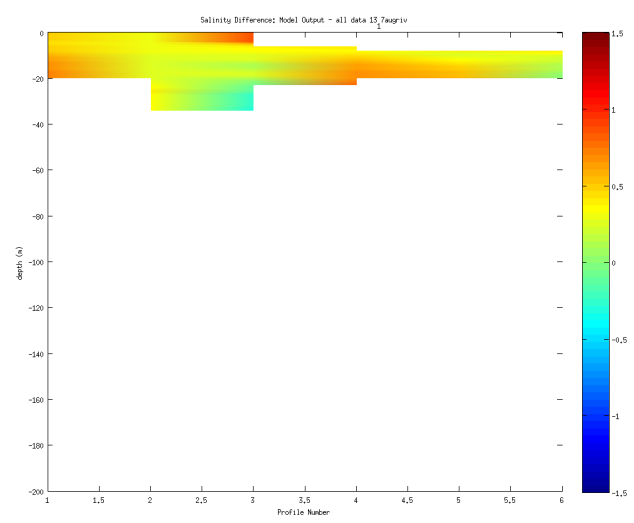

(c) Test 6 (7 cells) @ $10 \mathrm{~m}$

Figure 4-8: Comparisons of salinity data (in profiles with known river discharge influence (Newhall et al., 2010)) with MSEAS salinity forecasts using different configurations of the bulk mixing model, with salinity relaxation to a depth of $10 \mathrm{~m}$. Plots show the data subtracted from the specified model output. The profile locations and data are shown in Figure 4-2. 


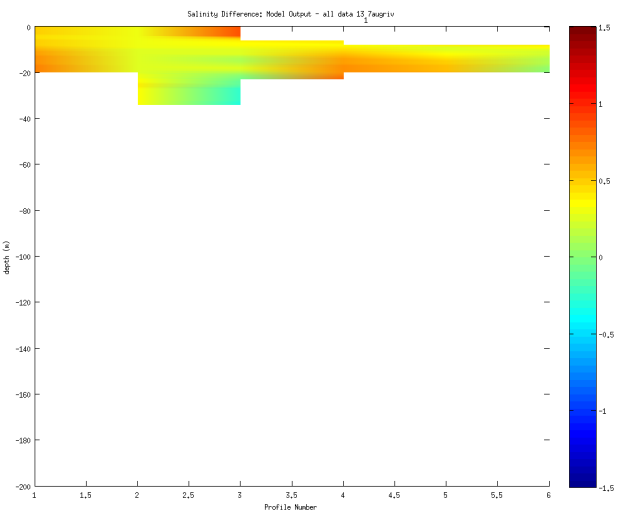

(a) Test $6(7$ cells $) @ 10 \mathrm{~m}$

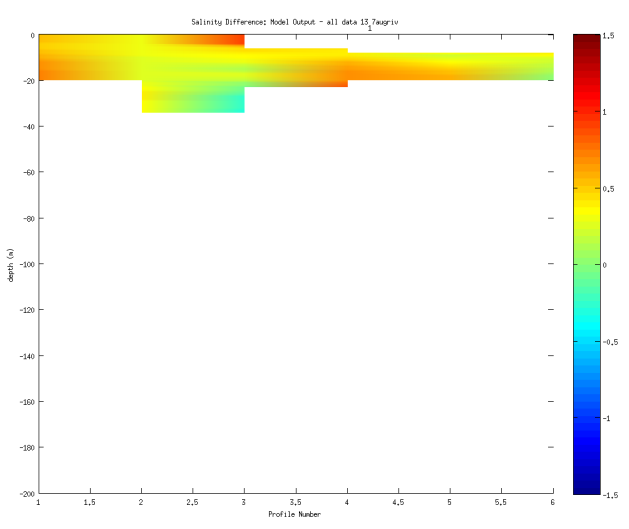

(c) Test 8 (14 cells) @ $10 \mathrm{~m}$

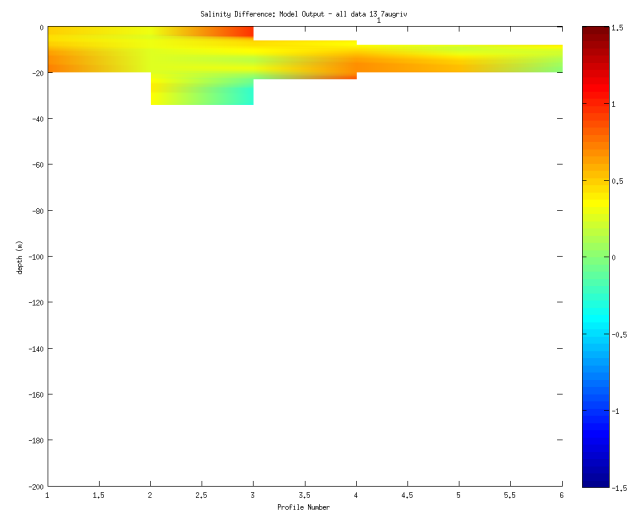

(b) Test 7 (10 cells) @ $10 \mathrm{~m}$

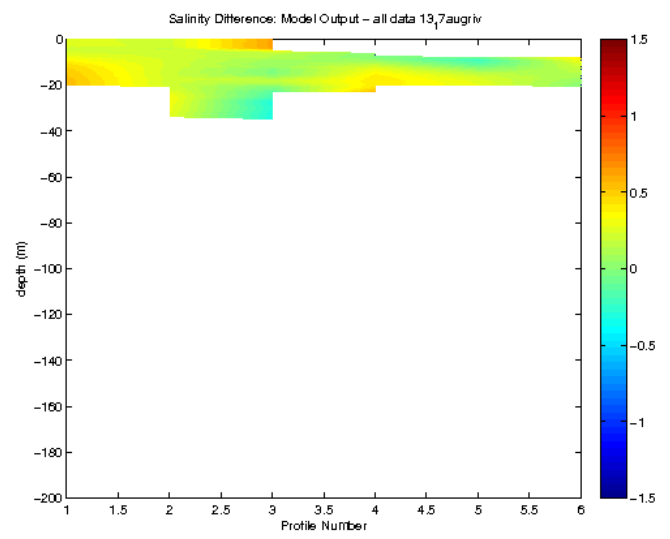

(d) Test 9 (25 cells) @ $10 \mathrm{~m}$

Figure 4-9: Comparisons of salinity data (in profiles with known river discharge influence (Newhall et al., 2010)) with MSEAS salinity forecasts using different configurations of the bulk mixing model, with salinity relaxation to a depth of $10 \mathrm{~m}$. Plots show the data subtracted from the specified model output.The profile locations and data are shown in Figure 4-2. 


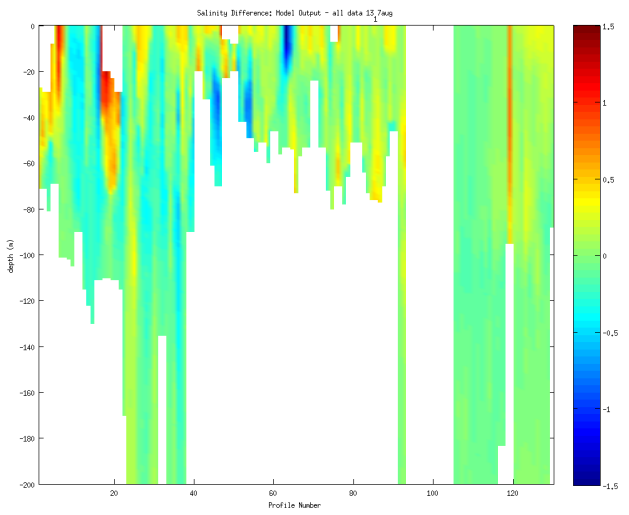

(a) Original (7 cells) @ $20 \mathrm{~m}$

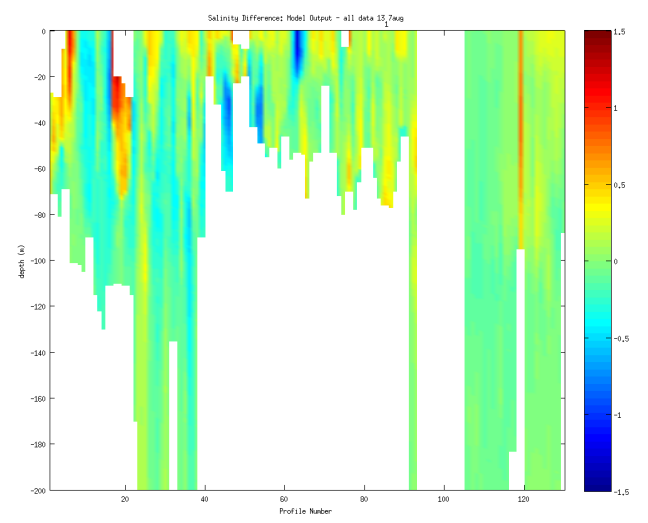

(c) Test 6 (7 cells) @ $20 \mathrm{~m}$

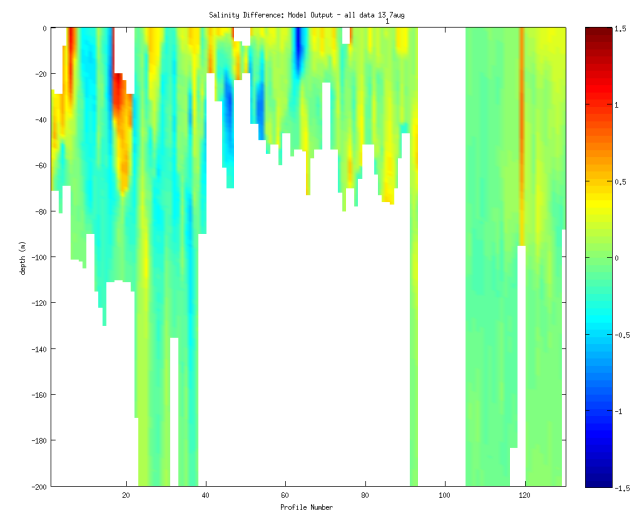

(e) Test 8 (14 cells) @ 20 m

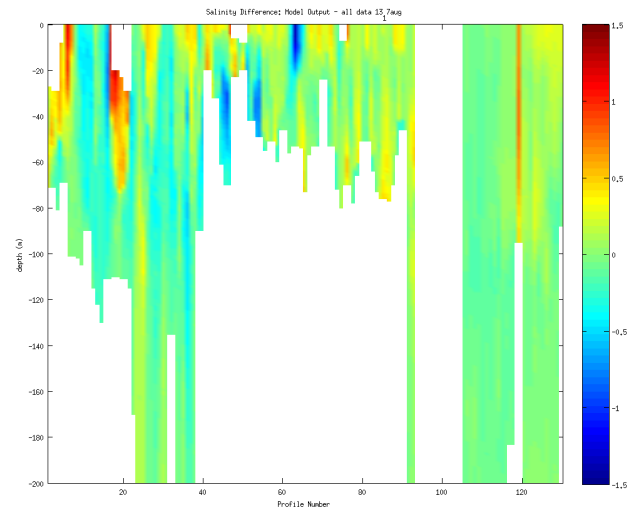

(b) Test 5 (7 cells) @ $20 \mathrm{~m}$

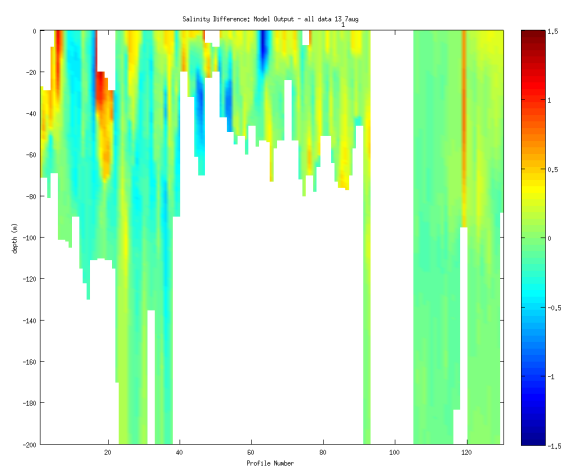

(d) Test 7 (10 cells) @ $20 \mathrm{~m}$

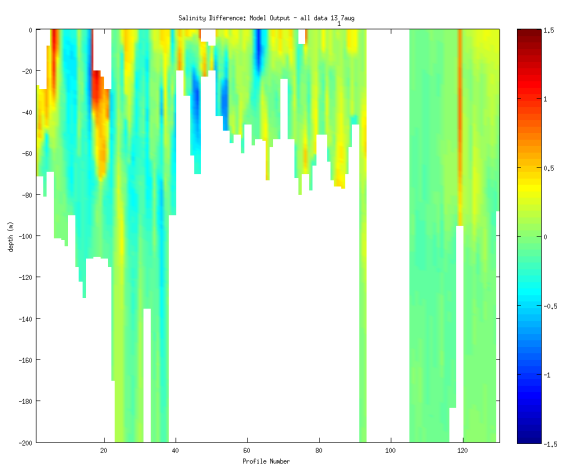

(f) Test 9 (25 cells) @ $20 \mathrm{~m}$

Figure 4-10: Comparisons of salinity data with MSEAS salinity forecasts using different configurations of the bulk mixing model, with salinity relaxation to a depth of $20 \mathrm{~m}$. Plots show the data subtracted from the specified model output. The profile locations are shown in Figure 4-1. 


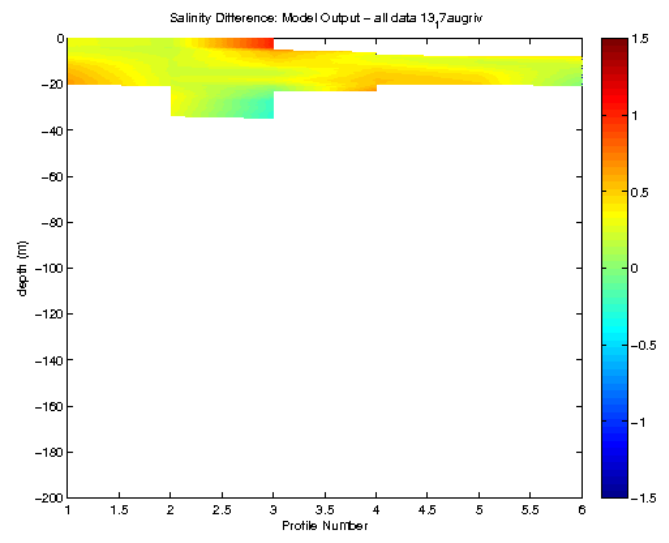

(a) Original (7 cells) @ $20 \mathrm{~m}$

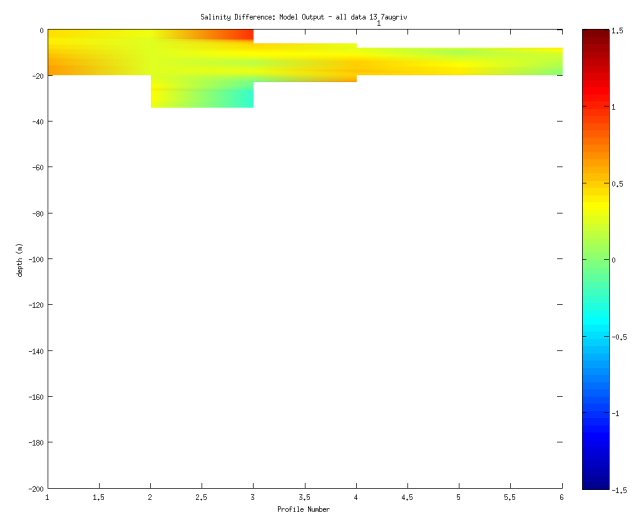

(b) Test 5 (7 cells) @ $20 \mathrm{~m}$

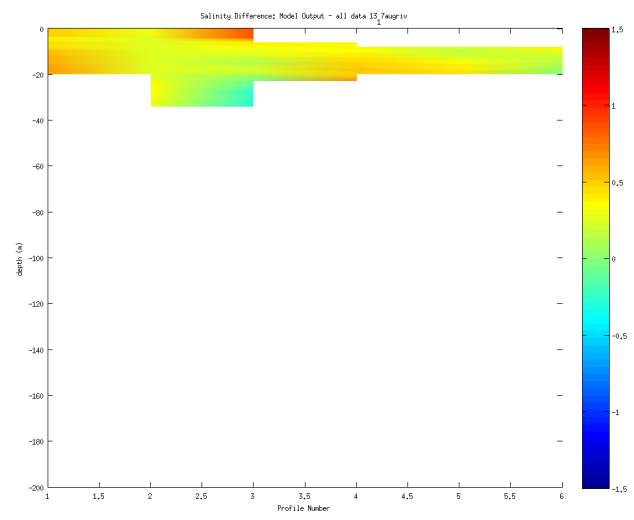

(c) Test 6 (7 cells) @ $20 \mathrm{~m}$

Figure 4-11: Comparisons of salinity data (in profiles with known river discharge influence (Newhall et al., 2010)) with MSEAS salinity forecasts using different configurations of the bulk mixing model, with salinity relaxation to a depth of $20 \mathrm{~m}$. Plots show the data subtracted from the specified model output. The profile locations and data are shown in Figure 4-2. 


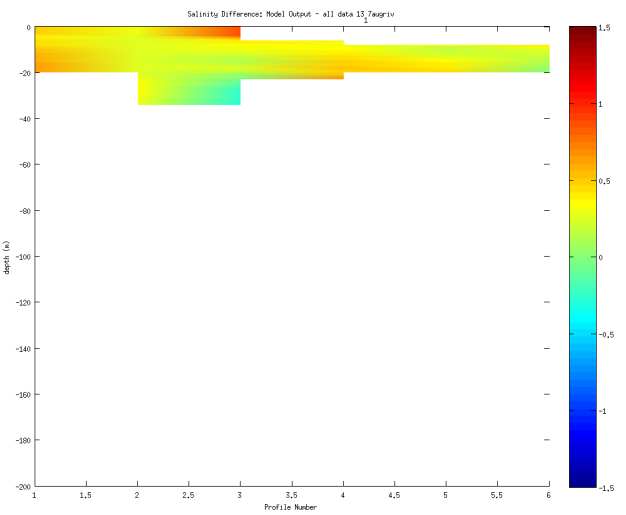

(a) Test 6 (7 cells) @ $20 \mathrm{~m}$

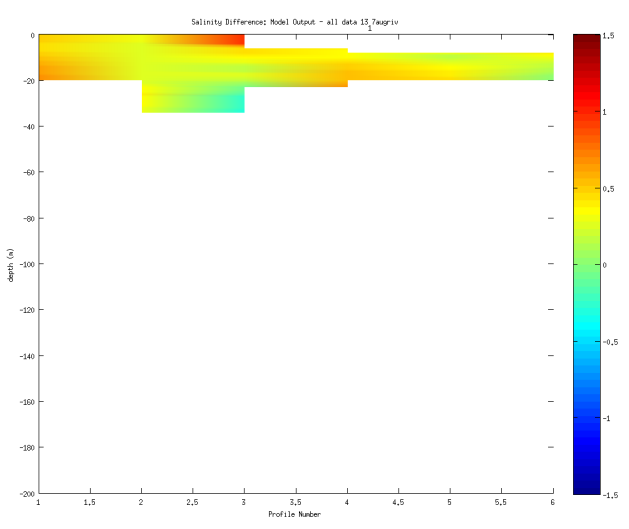

(c) Test 8 (14 cells) @ $20 \mathrm{~m}$

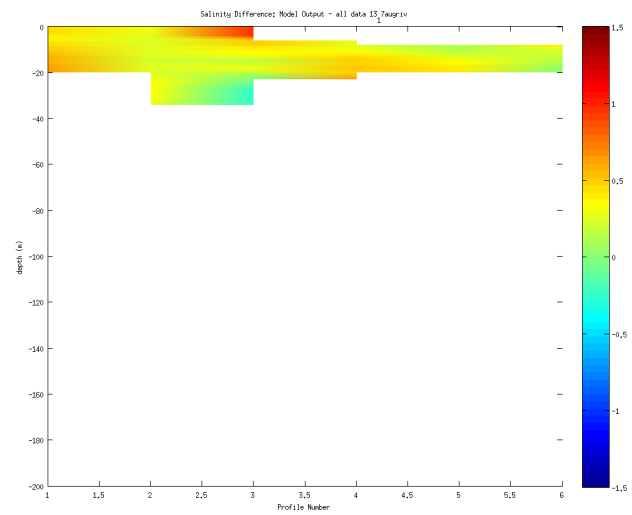

(b) Test 7 (10 cells) @ $20 \mathrm{~m}$

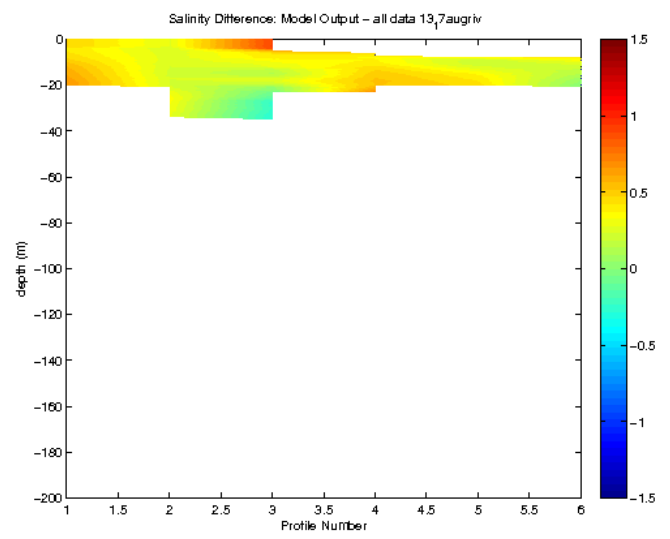

(d) Test 9 (25 cells) @ $20 \mathrm{~m}$

Figure 4-12: Comparisons of salinity data (in profiles with known river discharge influence (Newhall et al., 2010)) with MSEAS salinity forecasts using different configurations of the bulk mixing model, with salinity relaxation to a depth of $20 \mathrm{~m}$. Plots show the data subtracted from the specified model output. The profile locations and data are shown in Figure 4-2. 


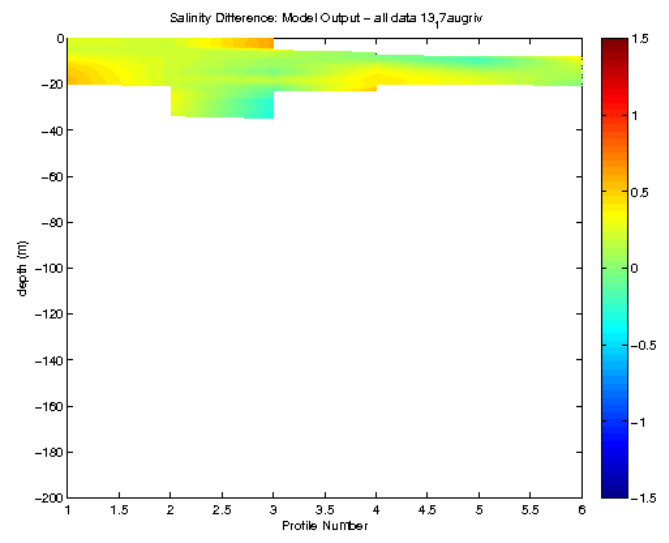

(a) Test 9 (25 cells) @ $10 \mathrm{~m}$

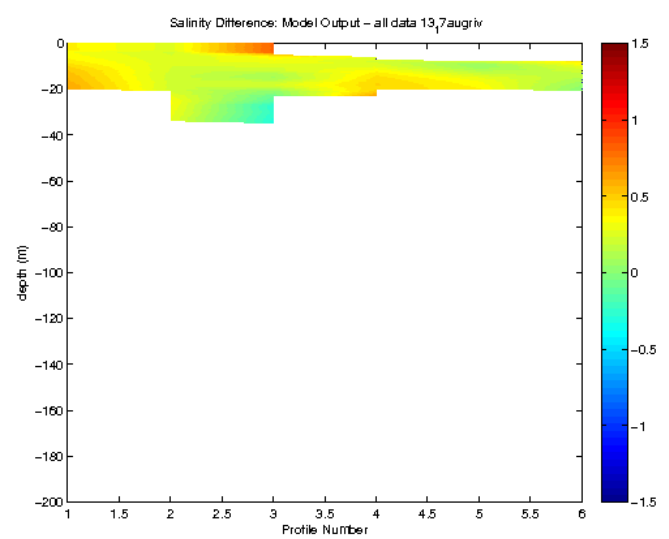

(b) Test 9 (25 cells) @ $15 \mathrm{~m}$

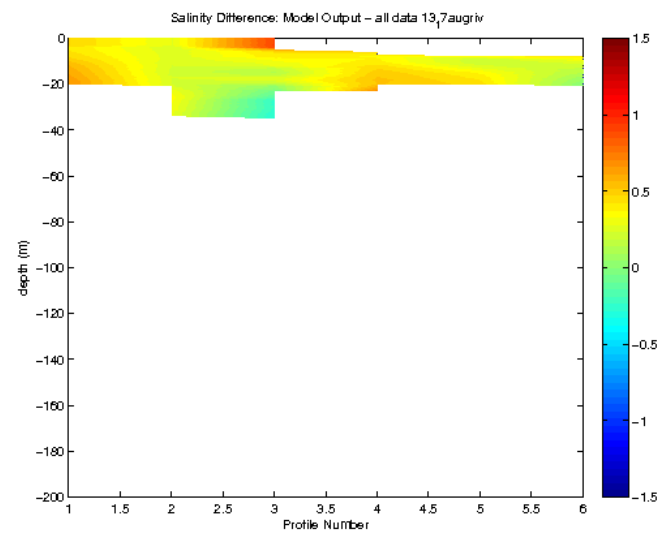

(c) Test 9 (25 cells) @ $20 \mathrm{~m}$

Figure 4-13: Comparisons of salinity data (in profiles with known river discharge influence (Newhall et al., 2010)) with MSEAS salinity forecasts using the same 25 cell configuration of the bulk mixing model, with salinity relaxation to a depth of 10 , 15 , and $20 \mathrm{~m}$. Plots show the data subtracted from the specified model output. The profile locations and data are shown in Figure 4-2. 


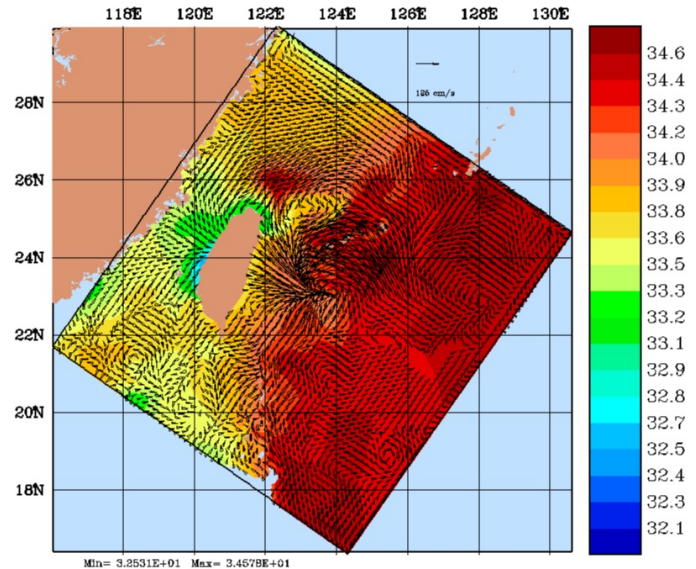

(a) August 07

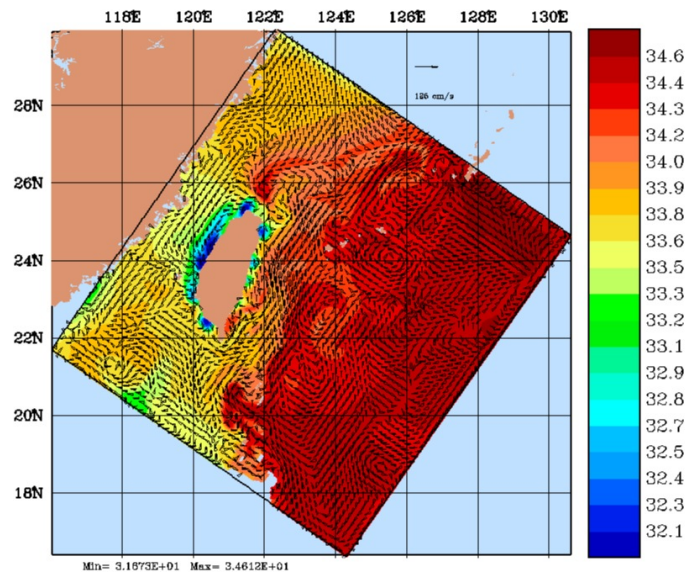

(c) August 13

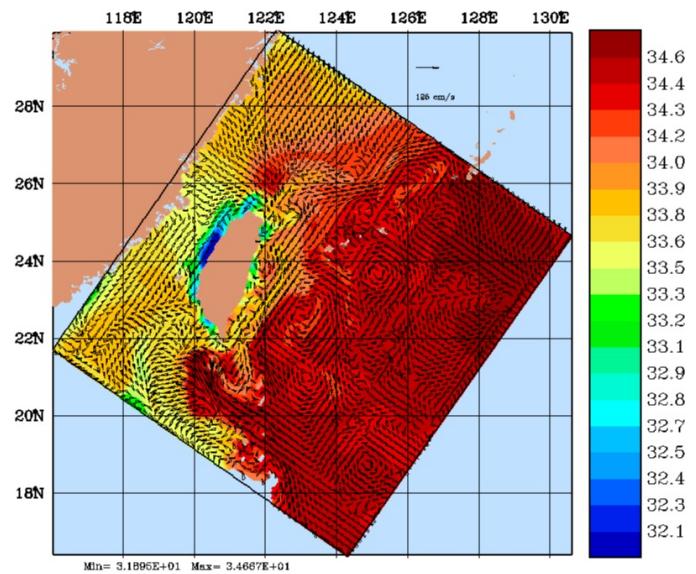

(e) August 19

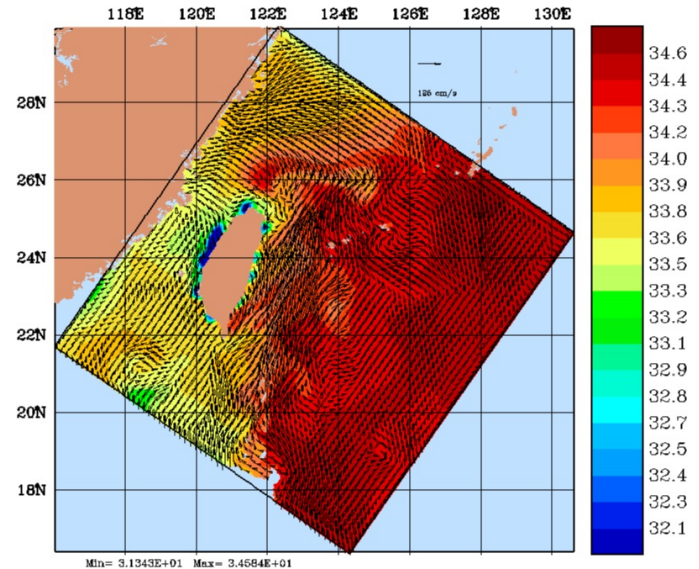

(b) August 09

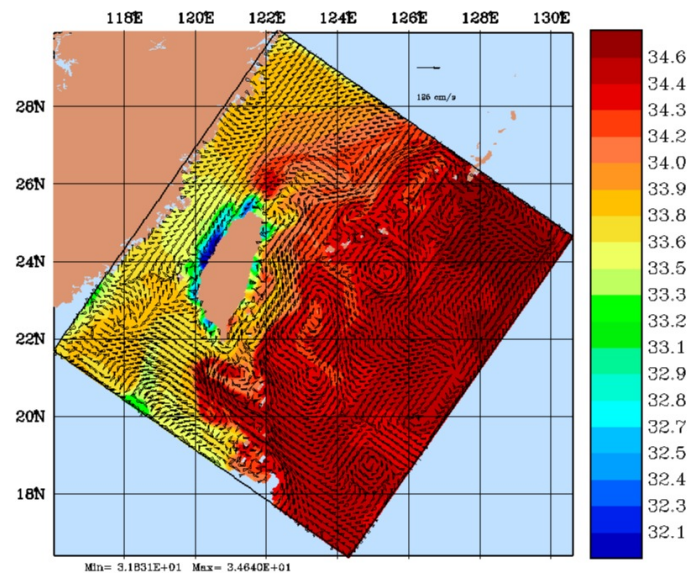

(d) August 17

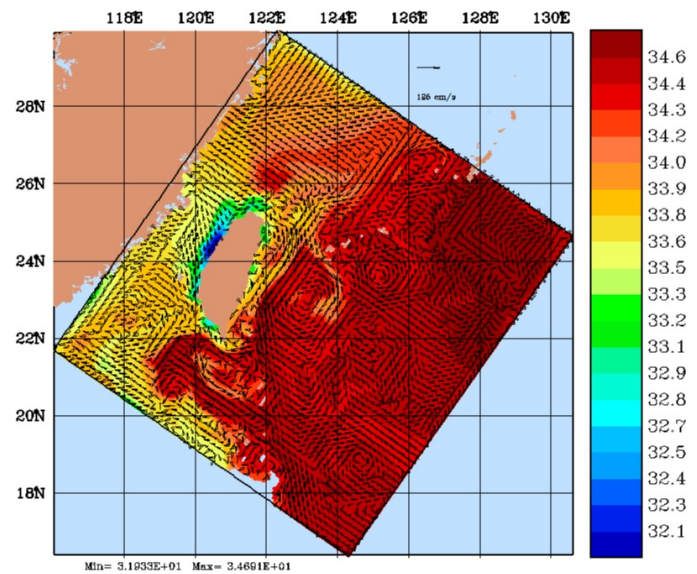

(f) August 25

Figure 4-14: Surface salinities forecast by the MSEAS ocean model with configuration Test 9 , using $\mathrm{n}=25$ finite-volume cells, with salinity relaxation applied to a depth of $10 \mathrm{~m}$. The configuration is shown in Figure 3-7(f). 


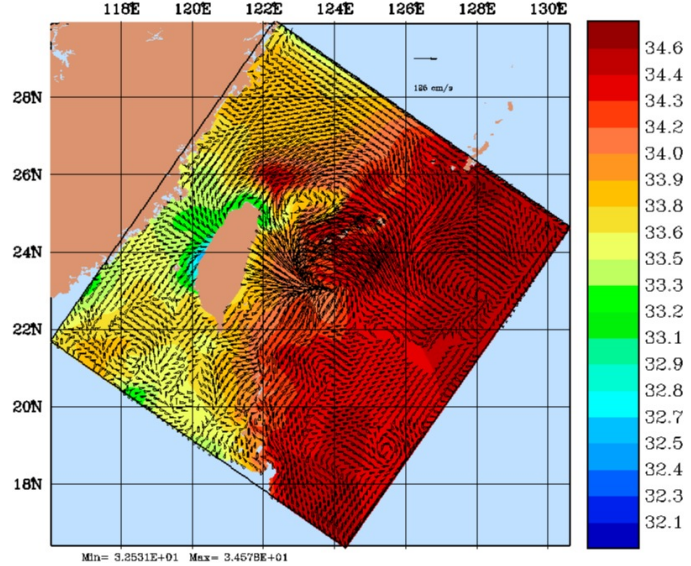

(a) August 07

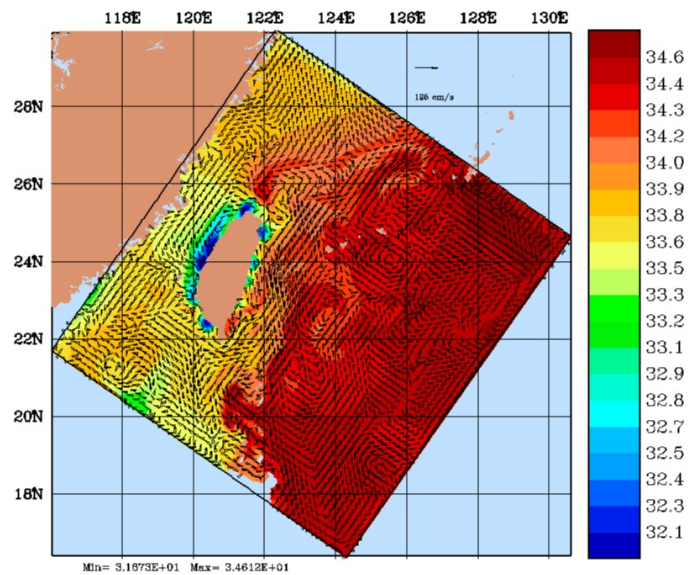

(c) August 13

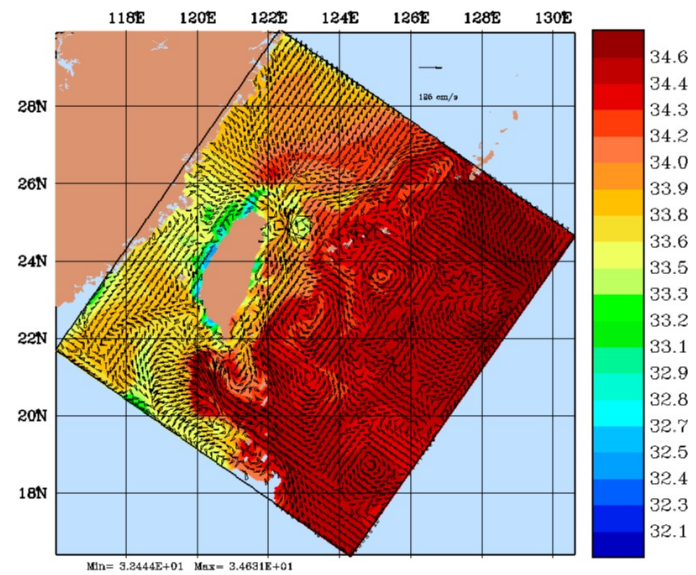

(e) August 19

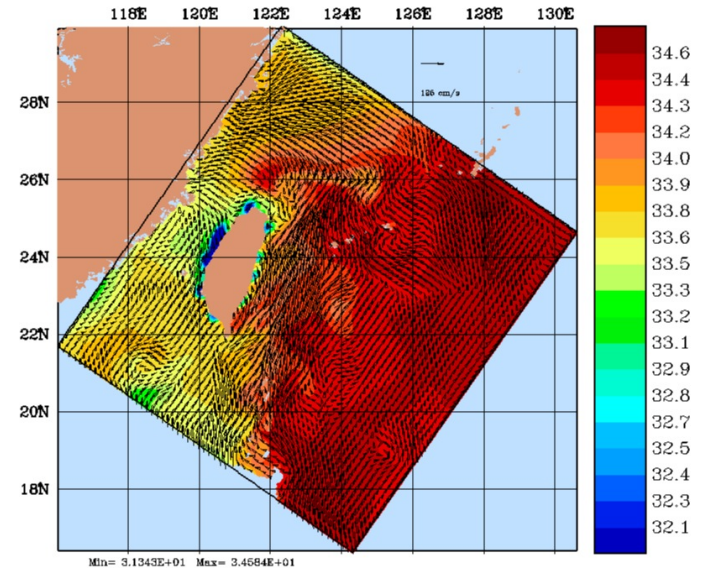

(b) August 09

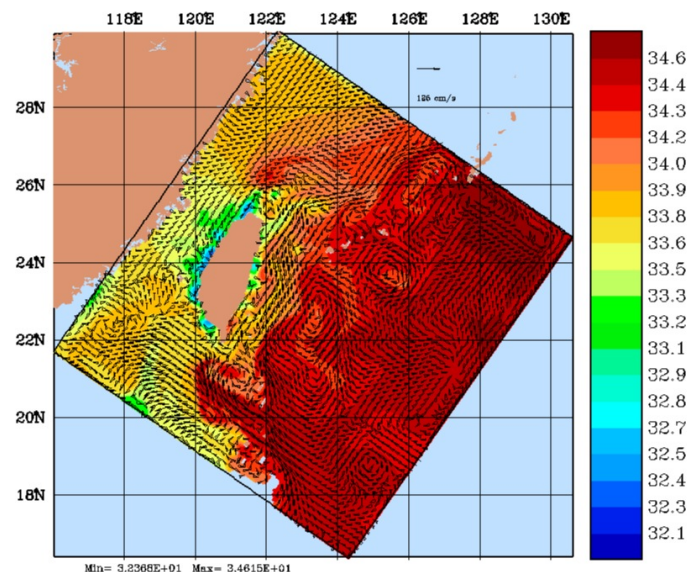

(d) August 17

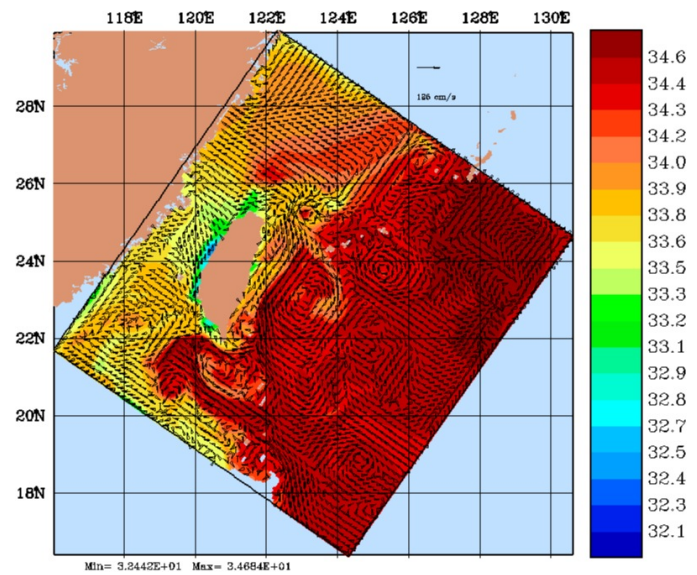

(f) August 25

Figure 4-15: Surface salinities forecast by the MSEAS ocean model with configuration Test 9 , using $\mathrm{n}=25$ finite-volume cells, with salinity relaxation applied to a depth of $10 \mathrm{~m}$. These results include data assimilation. The configuration is shown in Figure 3-7(f). 


\section{Chapter 5}

\section{Conclusion}

This work focused on the improvement of ocean forecasting techniques in the highly dynamic and complex region surrounding Taiwan. We did this by focusing on a period of time immediately following the passage of Typhoon Morakot, which brought an unprecedented amount of rainfall within a very short time period. This freshwater resulted in excessive river discharge, and the work of this thesis was to model this discharge via a bulk mixing and river discharge model to improve the ability of primitive-equation ocean models in forecasting salinity responses to extreme weather events.

By varying the shape and size of the bulk mixing model footprint, as well as the depth, and examining the resulting impacts on ocean salinity forecasts, we were able to determine the optimal combination of salinity relaxation factors for highest accuracy. Utilizing data collected by the Quantifying, Predicting, and Exploiting Uncertainty Department Research Initiative (QPE DRI), the bulk mixing and river discharge model was carefully tuned to optimal performance.

Understanding the impact of extreme weather events on oceanic properties and improving ocean model forecasting allows users to predict the changing environment

more accurately. Enhanced knowledge of the environment gives the advantage to the decision maker: knowledge is power, and in an environment as vast and complex as the ocean, even a small advantage can make a big difference. 


\subsection{Future Work}

Research begets research, and this work is no exception. During the course of this project, many other areas of potential improvement were discovered. Some of these were considered for this work, but constraints of time prohibited a thorough investigation of all possibilites. We include some of these here for others interested in furthering this work.

\subsubsection{Variation of Salinity Relaxation Factors}

The river discharge model and bulk mixing model, in its current form, applies salinity uniformly throughout a set number of finite-volume cells assigned to an individual river per Equation 3.11. In reality, we expect that the impact of the freshwater discharge is felt most strongly in ocean waters closest to the river mouth, with effects dissipating as distance from the river mouth increases. Factors such as annual mean discharge, topography, instantaneous river discharge rates, and riverbed depth create much variation between the individual river impacts on the surrounding ocean waters. Modeling these smaller effects may have significant impact on the river discharge and bulk mixing models' ability to improve ocean forecasts. A trade-off between model complexity and accuracy must be considered.

The number of finite-volume grid cells per river could be adjusted to a variable value, with each river having a different size footprint within the model. The salinity relaxation could also be applied at variable depths within each river's footprint. The salinity value used in the bulk mixing model could be applied non-uniformly throughout the footprint.

\subsubsection{MSEAS Primitive-Equation Model}

This study utilized the MSEAS primitive-equation ocean model. The many different model runs were run over the same domain as standalone runs. A study of the impact of domain size and/or grid resolution would enhance our knowledge of the model's response to the river discharge model. The model is capable of utilizing 
nested runs to increase resolution, and this technique would also contribute to a better understanding of the interactions between the primitive-equation model and the river discharge model.

\subsubsection{New Discharge Data}

Since the development of the original river discharge model, more river discharge data have become available. Jan et al. (2013) has discharge data for two additional rivers, the Zēngwén $(i=2)$ and the Wu1 $(i=4)$ Rivers (Figure 5-1). This data could help to develop a more accurate time series to be used for the river discharge model. An interesting feature of this data is that the Zēngwén River has a peak discharge rate that is approximately equal to the peak discharge rate of the Gāopíng River. Recall from Table 2.1 that the Zēngwén River has an annual mean discharge of $50 \mathrm{~m}^{3} / \mathrm{s}$, while the Gāopíng River has an annual mean discharge rate of $220 \mathrm{~m}^{3} / \mathrm{s}$. The Wū River, with an annual mean discharge of $120 \mathrm{~m}^{3} / \mathrm{s}$, has a peak discharge rate that is an order of magnitude lower than that of the other three rivers. This indicates that dividing the discharge between rivers based on annual mean discharge rates introduces a source of error. However, Figure 2-10(a) shows the geographical location of these four rivers. The Wū River is the furthest north; the other rivers are sourced high in the mountains of the southern part of Taiwan. It is important to note that the heaviest rainfall ocurred on the southern part of the island (see Figure 2-8). Then it would be expected that the Gāopíng, Zēngwén, Zhuóshuǐi Rivers would have higher peak discharge rates from Typhoon Morakot rainfall; this supports the basin-averaged rainfall distribution approach of Mirabito et al. (2012). 


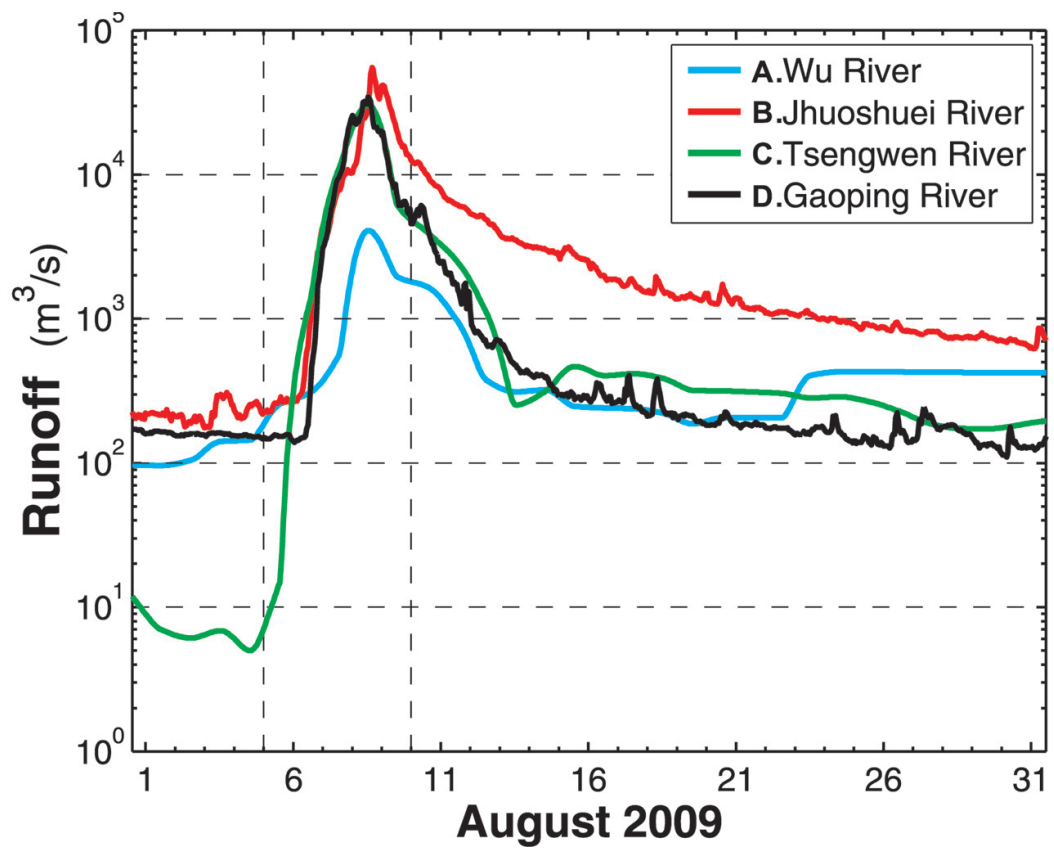

Figure 5-1: Discharge Data for the Gāopíng $(i=1)$, Zēngwén $(i=2)$, Zhuóshuǔi $(i=3)$, and $\mathrm{W} \overline{\mathrm{u}}(i=4)$ Rivers from August 2009. (Jan et al., 2013) 


\section{Bibliography}

Cooper, G. A. and Falvey, R. J. (2009). Annual Tropical Cyclone Report. Technical report, U.S. Naval Maritime Forecast Center/ Joint Typhoon Warning Center Pearl Harbor, Hawaii, Pearl Harbor, HI.

Cushman-Roisin, B. and Beckers, J.-M. (2011). Introduction to geophysical fluid dynamics: physical and numerical aspects, volume 101. Academic Press.

Gawarkiewicz, G., Jan, S., Lermusiaux, P. F. J., McClean, J. L., Centurioni, L., Taylor, K., Cornuelle, B., Duda, T. F., Wang, J., Yang, Y. J., Sanford, T., Lien, R.-C., Lee, C., Lee, M.-A., Leslie, W., Haley, Jr., P. J., Niiler, P. P., Gopalakrishnan, G., Velez-Belchi, P., Lee, D.-K., and Kim, Y. Y. (2011). Circulation and intrusions northeast of Taiwan: Chasing and predicting uncertainty in the cold dome. Oceanography, 24(4):110-121.

Gutro, R. (2009). NASA Satellite Sees Severe Flooding Rains from Deadly Typhoon Morakot. http://www.nasa.gov/mission_pages/hurricanes/archives/2009/ h2009_Morakot.html. [Online; accessed 28-July-2014].

Haley, Jr., P. J., Agarwal, A., and Lermusiaux, P. F. J. (2014). Optimizing velocities and transports for complex coastal regions and archipelagos. Ocean Modeling. subjudice.

Haley, Jr., P. J. and Lermusiaux, P. F. J. (2010). Multiscale two-way embedding schemes for free-surface primitive equations in the "Multidisciplinary Simulation, Estimation and Assimilation System". Ocean Dynamics, 60(6):1497-1537.

Jan, S., Chen, C.-C., Tsai, Y.-L., Yang, Y. J., Wang, C.-S., Gawarkiewicz, G., Lien, R.-C., Centurioni, L., and Kuo, J.-Y. (2011). Mean structure and variability of the cold dome northeast of taiwan. Oceanography, 24(4):99-109.

Jan, S., Wang, J., Yang, Y. J., Hung, C.-C., Chern, C.-S., Gawarkiewicz, G., Lien, R.C., Centurioni, L., Kuo, J.-Y., and Wang, B. (2013). Observations of a freshwater pulse induced by typhoon morakot off the northern coast of taiwan in august 2009 . Journal of Marine Research, 71:19-46.

Joint Typhoon Warning Center (2009). JTWC Western North Pacific Best Track Data. http://jtwccdn.appspot.com/NOOC/nmfc-ph/RSS/jtwc/best_tracks/ 2009/2009s-bwp/bwp092009.txt. [Online; accessed 28-July-2014]. 
Lang, S. (2009). NASA's TRMM Satellite Sees Typhoon Morakot's Massive Flooding in Taiwan. http://www . nasa.gov/mission_pages/hurricanes/archives/2009/ h2009_Morakot.html. [Online; accessed 28-July-2014].

Lermusiaux, P. F. J., Xu, J., Chen, C.-F., Jan, S., Chiu, L., and Yang, Y.-J. (2010). Coupled ocean-acoustic prediction of transmission loss in a continental shelfbreak region: Predictive skill, uncertainty quantification, and dynamical sensitivities. IEEE Journal of Oceanic Engineering, 35(4):895-916.

Leslie, W. G. (2012). QPE Initialization Condition Data and Model Comparison. http://mseas.mit.edu/group/Projects/QPE/Initialization_Study/. [Online; accessed 01-August-2014].

Liu, J. T. (2010). Gaoping river discharge and sediment content measured at Liling gauging station (1991-2009). Microsoft PowerPoint slides.

Mirabito, C., Haley, Jr., P. J., Lermusiaux, P. F. J., and Leslie, W. G. (2012). A River Discharge Model for Coastal Taiwan during Typhoon Morakot. MSEAS Report 13, Department of Mechanical Engineering, Massachusetts Institute of Technology, Cambridge, MA.

NASA/MODIS Rapid Response (2009). http://www.nasa.gov/images/content/ 376906main_MODISMorakot_full.jpg. [Online; accessed 28-July-2014].

National Hurricane Center (2014). Latitude-Longitude Distance Calculator. http: //www.nhc.noaa.gov/gccalc.shtml. [Online; accessed 01-August-2014].

Naval Research Laboratory (2012). COAMPS overview. http: //www.nrlmry . navy . mil \penalty0/coamps \penalty0-web\penalty0/web\penalty0/view.

Newhall, A. E., Gawarkiewicz, G. G., Lynch, J. F., Duda, T. F., McPhee, N. M., Marquette, C. D., Lin, Y.-T., Jan, S., Wang, J., Chen, C.-F., Chiu, L. Y. S., Yang, Y. J., Wei, R.-C., Emerson, C., Morton, D., Abbot, T., Abbot, P., Calder, B., Mayer, L., and Lermusiaux, P. F. J. (2010). Acoustics and Oceanographic Observations Collected During the QPE Experiment by Research Vessels OR1, OR2 and OR3 in the East China Sea in the Summer of 2009. MSEAS Report 06, Woods Hole Oceanographic Institution, Woods Hole, MA.

Özgökmen, T. M. and Chassignet, E. P. (2002). Dynamics of two-dimensional turbulent bottom gravity currents. Journal of Physical Oceanography, 32(5):1460-1478.

Rudnick, D. L., Jan, S., Centurioni, L., Lee, C. M., Lien, R.-C., Wang, J., Lee, D.K., Tseng, R.-S., Kim, Y. Y., and Chern, C.-S. (2011). Seasonal and mesoscale variability of the kuroshio near its origin. Oceanography, 24(4):52-63.

SSAI/NASA, Hal Pierce (2009). http://www.nasa.gov/images/content/ 378392main_20090812_TRMMImage1_full.jpg. [Online; accessed 28-July-2014]. 
Taiwan Central Weather Bureau (2014). FAQ for Earthquake. http://www . cwb.gov . tw/V7e/knowledge/encyclopedia/eq000.htm. [Online; accessed 28-July-2014].

Talley, L. D., Pickard, G. L., Emery, W. J., and Swift, J. H. (2011). Descriptive Physical Oceanography: An Introduction. Elsevier Academic Press, Oxford, UK, 6th edition edition.

Tang, T., Hsueh, Y., Yang, Y., and Ma, J. (1999). Continental slope flow northeast of taiwan. Journal of Physical Oceanography, 29(6):1353-1362.

U. S. Central Intelligence Agency (2014). The World Factbook: Taiwan. https://www.cia.gov/library/publications/the-world-factbook/ geos/tw.html. [Online; accessed 28-July-2014].

Woods Hole Oceanographic Institution (2014). Underwater Vehicles: Towed Vehicles: SeaSoar. http://www.whoi.edu/main/seasoar. [Online; accessed 01-August2014]. 